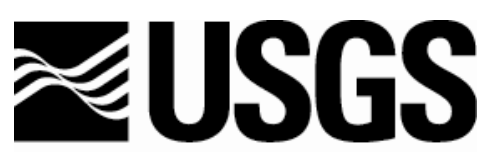

science for a changing world

Prepared in cooperation with the Office of Repository Development of the U.S. Department of Energy, under Interagency Agreement DE-Al08-02RW12167

\title{
Selected Ground-Water Data for Yucca Mountain Region, Southern Nevada and Eastern California, January-December 2003
}

Open-File Report 2005-1286 
(Back of Cover) 


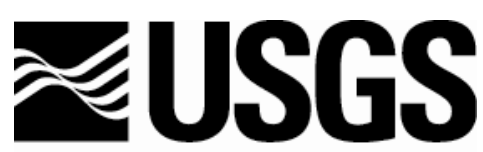

science for a changing world

Prepared in cooperation with the Office of Repository Development of the U.S. Department of Energy, under Interagency Agreement DE-Al08-02RW12167

\section{Selected Ground-Water Data for Yucca Mountain Region, Southern Nevada and Eastern California, January-December 2003}

By Richard J. La Camera, Glenn L. Locke, and Aron M. Habte

Open-File Report 2005-1286 


\section{U.S. Department of the Interior \\ Gale A. Norton, Secretary}

\section{U.S. Geological Survey \\ P. Patrick Leahy, Acting Director}

U.S. Geological Survey, Carson City, Nevada, 2005

For product and ordering information:

World Wide Web: http://www.usgs.gov/pubprod

Telephone: 1-888-ASK-USGS

For more information on the USGS - the Federal source for science about the Earth, its natural and living resources, natural hazards, and the environment:

World Wide Web: http://www.usgs.gov

Telephone: 1-888-ASK-USGS

For additional information on Nevada contact:

Director

USGS, Nevada Water Science Center

333 W. Nye Lane, Room 203

Carson City, NV 89706-0866

email: GS-W-NVpublic-info@usgs.gov

http://nevada.usgs.gov

Any use of trade, firm, or product names is for descriptive purposes only and does not imply endorsement by the U.S. Government

Although this report is in the public domain, permission must be secured from the individual copyright owners to reproduce any copyrighted material contained within this report. 


\section{CONTENTS}

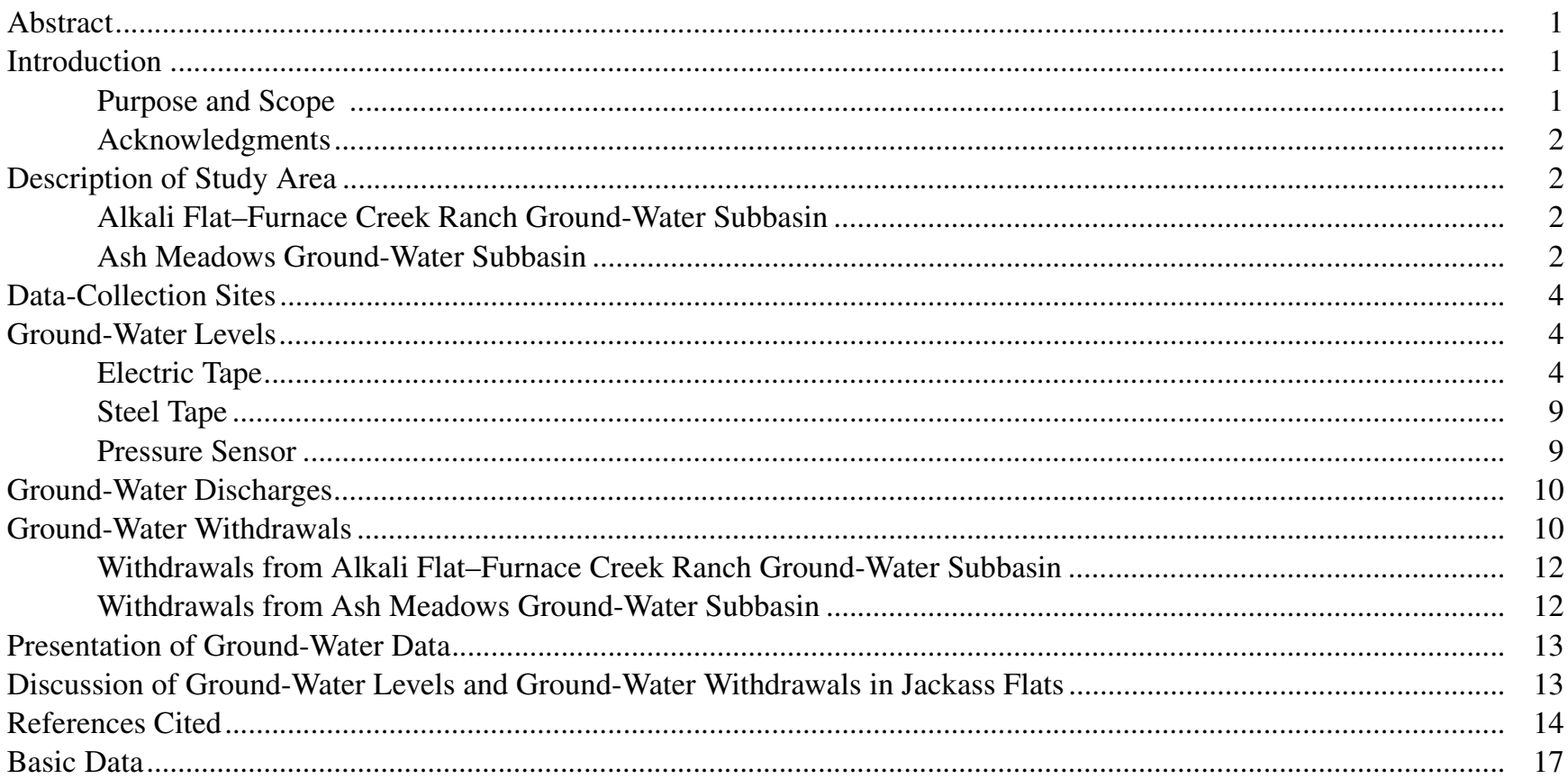

\section{FIGURES}

1. Map showing location of data-collection sites in the Yucca Mountain region, southern Nevada and eastern California, 2003

2-5. Graphs showing periodic water levels for selected sites through 2003 at which primary contributing units are:

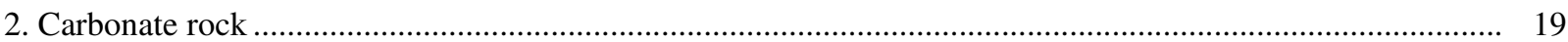

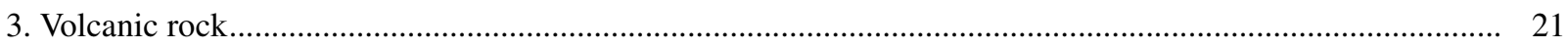

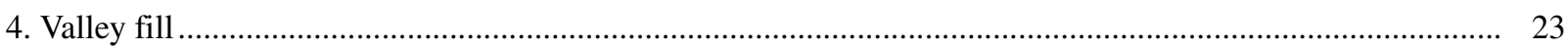

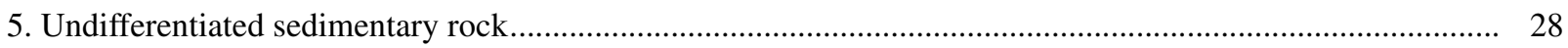

6. Graph showing daily average water levels in well JF-3, May 1992-December 2003 and in well AD-6, July 1992-December 2003.

7-9. Graphs showing discharge at:

7. Sites AM-1a (Fairbanks Spring), AM-5a (Crystal Pool), and AM-8 (Big Spring), 1910-2003.................... 30

8. Sites AM-2 (Five Springs Well) and DV-2 (Navel Spring), 1990-2003 ................................................ 31

9. Site DV-1 (Texas Spring), 1989-2003 .......................................................................................... 31

10. Map showing location of ground-water withdrawal sites and general areas of ground-water withdrawals in the Yucca Mountain region of southern Nevada and eastern California, January-December 2003

11-12. Graphs showing available estimates of annual ground-water withdrawals for selected areas within:

11. Alkali Flat-Furnace Creek Ranch ground-water subbasin, 1959-2003 ..................................................... 33

12. Ash Meadows ground-water subbasin, 1962-2003 …................................................................... 34

13. Graphs showing water-level altitudes in wells JF-1, JF-2, JF-2a, J-13, J-11, J-12, and JF-3, and estimated annual ground-water withdrawals from Jackass Flats, 1983-2003

14. Graphs showing median water-level altitudes and average deviation of water levels for wells JF-1, JF-2, JF-2a, J-13, J-11, J-12, and JF-3, and estimated annual ground-water withdrawals from Jackass Flats, for 1992-93 baseline period and for 1994-2003 


\section{TABLES}

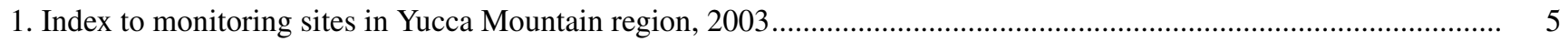

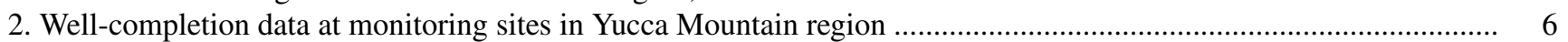

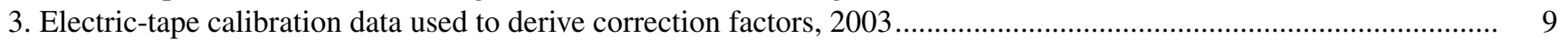

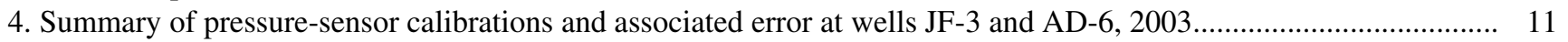

5. Periodic water-level data at monitoring sites in Yucca Mountain region, 2003 ....................................................40

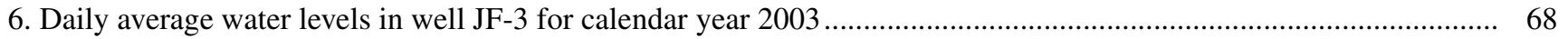

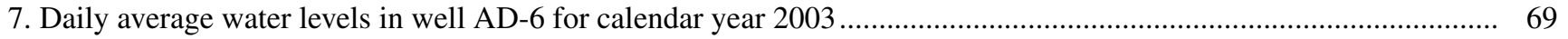

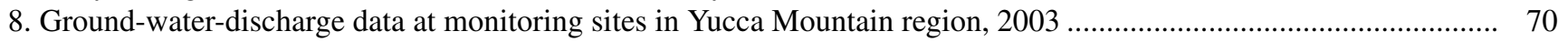

9. Estimated annual ground-water withdrawals from wells in Yucca Mountain region, 1959-2003 ............................ 72

10. Minimum, maximum, and median water-level altitudes, and average deviation of measurements, at selected wells in Jackass Flats for the baseline period 1992-93 and for calendar years 1994

through 2003

\section{CONVERSION FACTORS AND VERTICAL DATUM}

\begin{tabular}{rll}
\hline Multiply & By & To obtain \\
acre & 4,047 & square meter \\
acre-foot (acre-ft) & 1,233 & cubic meter \\
foot (ft) & 0.3048 & ceter \\
inch (in.) & 2.54 & kilometer \\
mile (mi) & 1.609 & cubic meter \\
gallon (gal) & 0.00378 & cubic meter \\
million gallons (Mgal) & 3,785 & liter per second \\
gallon per minute $\left(\mathrm{gal} / \mathrm{min}^{2}\right)$ & 0.06309 & kilopascal \\
pound per square inch (lb/in $\left.{ }^{2}\right)$ & 6.895 & \\
\hline
\end{tabular}

Temperature: Degrees Celsius $\left({ }^{\circ} \mathrm{C}\right)$ can be converted to degrees Fahrenheit $\left({ }^{\circ} \mathrm{F}\right)$ by using the formula ${ }^{\circ} \mathrm{F}=\left[1.8\left({ }^{\circ} \mathrm{C}\right)\right]+32$. Degrees Fahrenheit can be converted to degrees Celsius by using the formula ${ }^{\circ} \mathrm{C}=0.556\left({ }^{\circ} \mathrm{F}-32\right)$.

Sea level: In this report, "sea level" refers to the National Geodetic Vertical Datum of 1929 (NGVD of 1929, formerly called

"Sea-Level Datum of 1929"), which is derived from a general adjustment of the first-order leveling networks of the United States and Canada. 


\title{
Selected Ground-Water Data for Yucca Mountain Region, Southern Nevada and Eastern California, January-December 2003
}

\author{
By Richard J. La Camera, Glenn L. Locke, and Aron M. Habte
}

\section{ABSTRACT}

The U.S. Geological Survey, in support of the U.S. Department of Energy, Office of Repository Development, collects, compiles, and summarizes hydrologic data in the Yucca Mountain region. These data are collected to allow assessments of ground-water resources during activities to determine the potential suitability or development of Yucca Mountain for storing high-level nuclear waste.

Data on ground-water levels at 35 wells and a fissure (Devils Hole), ground-water discharge at 5 springs and a flowing well, and total reported ground-water withdrawals within Crater Flat, Jackass Flats, Mercury Valley, and the Amargosa Desert are tabulated from January through December 2003. Historical data that were revised from those published in previous reports on selected ground-water data for the Yucca Mountain region also are tabulated. Historical data on water levels, discharges, and withdrawals are presented graphically to indicate variations through time.

A statistical summary of ground-water levels at seven wells in Jackass Flats is presented for the period 1992-2003 to indicate potential effects of ground-water withdrawals associated with U.S. Department of Energy activities near Yucca Mountain. The statistical summary includes the annual number of measurements, maximum, minimum, and median waterlevel altitudes, and average deviation of measured water-level altitudes compared to the 1992-93 baseline period. At seven wells in Jackass Flats, median water levels for 2003 were slightly higher (0.4-2.8 feet) than their median water levels for 1992-93.

\section{INTRODUCTION}

Activities to determine the potential suitability or development of Yucca Mountain for storing high-level nuclear waste are in progress or planned. The U.S. Department of Energy (DOE) has declared that all facilities and investigations associated with such activities will be operated in a manner that maintains or protects environmental quality, and has established programs to allow assessments of environmental quality. In April 1989, the U.S. Geological Survey (USGS) began a cooperative program with DOE to develop a ground-water-resources monitoring program in the vicinity of Yucca Mountain. The purposes of the monitoring program are to (1) document the historical and current conditions of ground-water resources, (2) detect and document changes in those resources during activities at Yucca Mountain, and (3) provide a basis for analyzing and identifying potential adverse effects on ground-water resources resulting from investigations and activities at Yucca Mountain.

\section{Purpose and Scope}

This report presents and summarizes hydrologic data collected as part of the USGS Environmental-Monitoring Program. Included are data for calendar year 2003 on groundwater levels at 35 wells and a fissure (Devils Hole), groundwater discharge at 5 springs and a flowing well, and total reported ground-water withdrawals within Crater Flat, Jackass Flats, Mercury Valley, and Amargosa Desert. Data on groundwater levels, discharges, and withdrawals that have been revised from those previously reported and those collected by other agencies (or collected as part of other programs) at the sites also are included.

A discussion of ground-water data for Jackass Flats includes a statistical summary of those data to indicate potential effects of withdrawals from wells in Jackass Flats on water levels near Yucca Mountain. Effects of these withdrawals may be detected in Jackass Flats before they are detected elsewhere in the Yucca Mountain region.

This report is the tenth in a series of reports as part of the USGS Environmental-Monitoring Program (USGS-EMP). Hereafter, the first nine reports are referred to as previous reports on selected ground-water data for the Yucca Mountain region. The previous reports and the data they contain are:

\begin{tabular}{ll}
\hline \multicolumn{1}{c}{ Report (see references cited) } & \multicolumn{1}{c}{ Data contained } \\
\hline La Camera and Westenburg (1994) & Earliest available data through 1992 \\
Hale and Westenburg (1995) & Data collected in 1993 \\
Westenburg and La Camera (1996) & Data collected in 1994 \\
La Camera and others (1996) & Data collected in 1995 \\
La Camera and Locke (1998) & Data collected in 1996 \\
La Camera and others (1999) & Data collected in 1997 \\
Locke (2001a) & Data collected in 1998 \\
Locke (2001b) & Data collected in 1999 \\
Locke and La Camera (2003) & Data collected in 2000 through 2002 \\
\hline
\end{tabular}


Additional information for sites CF-2, JF-1, JF-2, JF-2a, $\mathrm{J}-13, \mathrm{~J}-11$, and $\mathrm{J}-12$ are included in Robison (1984), Robison and others (1988), Gemmell (1990), McKinley and others (1991), O’Brien (1991, 1993), Luckey and others (1993), Boucher (1994a), Lobmeyer and others (1995), O'Brien and others (1995), Graves and others (1996), Tucci and others (1996a, 1996b), Graves (1998), Graves and Goemaat (1998), Graves (2000), and Savard (2001).

\section{Acknowledgments}

Several organizations and programs contributed to this report. Specifically, data were provided by the Harry Reid Center for Environmental Studies (HRC) at the University of Nevada, Las Vegas; National Park Service (NPS); U.S. Fish and Wildlife Service (USFWS); Nevada Department of Conservation and Natural Resources, Division of Water Resources (NDWR); Nevada Department of Transportation; Bechtel Nevada; Bechtel SAIC Company, LLC; Fenix and Scisson, Inc.; Raytheon Services Nevada; Reynolds Electrical and Engineering Company; U.S. Borax Corp.; U.S. Nevada Gold Search; Barrick Bullfrog, Inc.; Cind-R-Lite Company; Sterling Gold Mining Corp.; USGS-Hydrologic Resources Management and Environmental Restoration Programs; and USGSYucca Mountain Project Branch studies of saturated-zone site hydrology and saturated-zone regional hydrology (USGS$\mathrm{SCP})$.

Additionally, the authors acknowledge the cooperation of the many individual property owners throughout the Amargosa Desert who allowed access to their property for the collection of hydrologic data.

\section{DESCRIPTION OF STUDY AREA}

The study area is the Yucca Mountain region of southern Nevada and eastern California (fig. 1). The boundary of the Yucca Mountain region, for purposes of this report, roughly coincides with the northern parts of Crater Flat and Jackass Flats, eastern parts of Rock Valley, Mercury Valley, and Amargosa Desert, Nev., and Death Valley Junction and Furnace Creek, Calif., to the south and west. The region is within the Great Basin, a subdivision of the Basin and Range Physiographic Province (Fenneman, 1931, p. 328).

The study area is in the Death Valley ground-water flow system (Harrill and others, 1988, sheet 1) and, within that flow system, the Alkali Flat-Furnace Creek Ranch and Ash Meadows ground-water subbasins. Each ground-water subbasin is a zone consisting of ground-water recharge areas and flow paths to points of discharge at land surface (Waddell and others, 1984, p. 36; Laczniak and others, 1996, p. 16 and pl. 1). Boundaries of the subbasins are defined on the basis of the location of recharge areas, discharge areas, low-permeability rocks, hydraulic gradients, and water chemistry. These boundaries are general indicators of restrictions on ground-water movement in the region.

The study area also is subdivided by hydrographic areas 1 (fig. 1). As defined by Rush (1968, p. 4), hydrographic areas generally consist of valleys (topographic lows) extending to their surrounding surface-water drainage divides (topographic highs). Hydrographic areas include Crater Flat, Jackass Flats, and Rock Valley, most of Mercury Valley and Amargosa Desert, and part of Death Valley (Rush, 1968; Harrill and others, 1988, sheet 2).

\section{Alkali Flat-Fumace Creek Ranch Ground-Water Subbasin}

Crater Flat and Jackass Flats (which include Yucca Mountain), most of Rock Valley, the west-central part of the Amargosa Desert, and part of Death Valley are in the Alkali Flat-Furnace Creek Ranch ground-water subbasin (fig. 1). Within this subbasin, sources of ground water principally are precipitation and subsurface inflow (Waddell and others, 1984, p. 36; Harrill and others, 1988, sheet 2; Laczniak and others, 1996, table 3). Precipitation occurs on the higher mesas and mountains within the subbasin and along the subbasin's north and northeast mountainous boundaries. Subsurface inflow into the subbasin occurs near Beatty from the Oasis Valley subbasin, near Ash Meadows from the Ash Meadows subbasin, and possibly from Cactus Flat (about 40 mi north of Beatty). Ground water discharges from springs in Death Valley and as evapotranspiration from Alkali Flat and Death Valley. Ground water generally flows to the south, southeast, or southwest (Kilroy, 1991, p. 9-13; Tucci and Burkhardt, 1995, p. 8; Laczniak and others, 1996, pl. 1).

\section{Ash Meadows Ground-Water Subbasin}

Part of Rock Valley, Mercury Valley, and most of the eastern part of the Amargosa Desert are within the Ash Meadows subbasin (fig. 1). The southeastern part of the Amargosa Desert includes the Ash Meadows spring-discharge area. The Ash Meadows spring-discharge area is a gently sloping land watered by numerous springs (Dudley and Larson, 1976, p. 5) at the southwestern edge of the subbasin.

\footnotetext{
${ }^{1}$ The U.S. Geological Survey and Nevada Division of Water Resources delineated formal hydrographic areas in Nevada systematically in the late 1960's for scientific and administrative purposes (Rush, 1968; Cardinalli and others, 1968). The official hydrographic area names, numbers, and geographic boundaries continue to be used in Geological Survey scientific reports and Division of Water Resources administrative activities. Extensions of hydrographic areas from Nevada into California and selected hydrographic areas in California have been delineated also by Harrill and others (1988, sheet 2).
} 


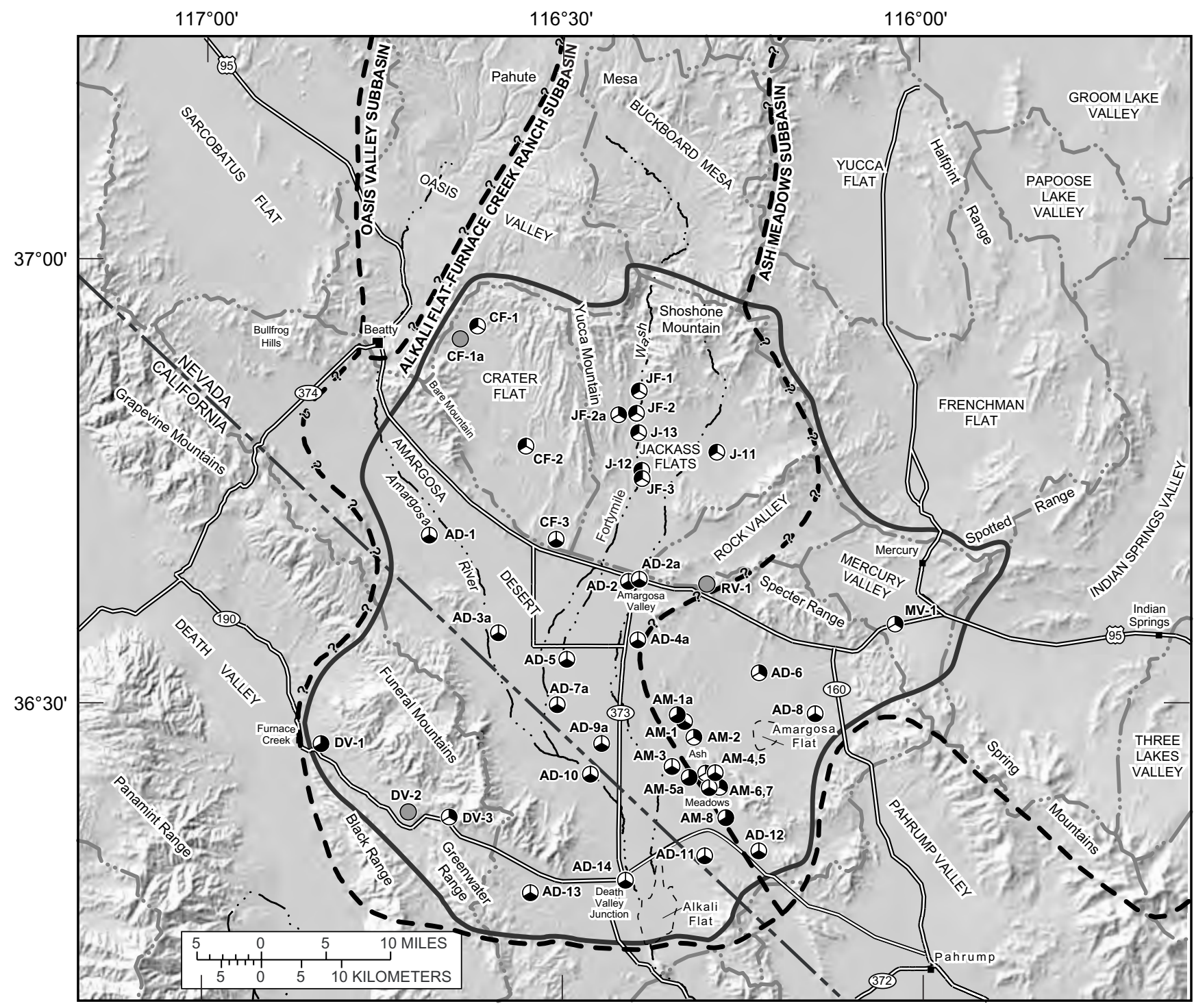

Base from U.S. Geological Survey digital elevation data, 1:250,000, 1987, and digital data, 1:100,000, 1981-89; Universal Transverse Mercator projection, Zone 11. Shaded-relief base from 1:250,000-scale Digital Elevation Model; sun illumination from northwest at 30 degrees above horizon

\section{EXPLANATION}

\section{Study-area boundary \\ - - Ground-water subbasin boundary- From Laczniak and others (1996, pl. 1). Queried where location uncertain}

\section{-..- Hydrographic-area boundary}

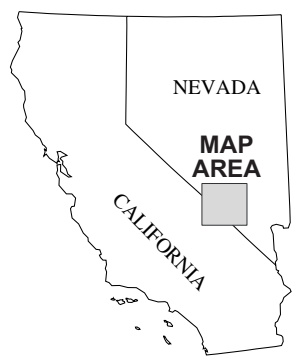

Data-collection site-Site number (table 1) and primary contributing unit are indicated
AD-6 Carbonate rock
CF-2 Q Volcanic rock
AD-1@ Valley fill
DV-2 Undifferentiated sedimentary rock
DV-1 Combined carbonate rock and valley fill

Figure 1. Location of data-collection sites in theYucca Mountain region, southern Nevada and eastern California, 2003. 
In the Ash Meadows ground-water subbasin, sources of ground water principally are precipitation and subsurface inflow (Laczniak and others, 1996, table 3). Precipitation occurs on the higher mountains within the subbasin and along the subbasin's north and northeast mountainous boundaries. Subsurface inflow possibly occurs from Railroad Valley and Pahranagat Valley along the basin's north and northeast boundaries (about 100 mi north of Ash Meadows; Winograd and Thordarson, 1975; Laczniak and others, 1996). Ground water discharges from springs and as evapotranspiration in the Ash Meadows area and possibly as underflow into the Alkali FlatFurnace Creek Ranch ground-water subbasin. Ground water in the subbasin generally flows to the south, west, or southwest (Harrill and others, 1988, sheet 2; Laczniak and others, 1996, p. 16-18 and pl. 1).

\section{DATA-COLLECTION SITES}

Locations of data-collection sites are shown in figure 1. Information on site identification, site location, site owner, and type of data contained in this report are listed in table 1 . The sequence of sites in table 1 is followed throughout the report. All sites are wells or springs except site AM-4 (Devils Hole), which is an open fissure that intersects the ground-water table. Well-construction data, source of well-construction data, and contributing lithologic units are listed in table 2. Excluded from table 2 are springs and a fissure for which construction data are not applicable.

Contributing units (table 2) are the principal saturated lithologic intervals at the sites that yield water to the well. For purposes of this report, contributing units are one or a combination of four general types: carbonate rock, valley fill, undifferentiated sedimentary rock, and volcanic rock. Wells characterized as having a contributing unit of carbonate or volcanic rock are wells with open intervals in those consolidated rocks. In and near the Amargosa Desert, wells characterized as having a contributing unit of valley fill are those with open intervals in unconsolidated valley-fill materials. Wells with open intervals in rocks that include argillite, limy sandstones and siltstones, or silty, sandy, and shaley limestones are characterized as having a contributing unit of undifferentiated sedimentary rock. Contributing units are identified by Dudley and Larson (1976), McKinley and others (1991), Robison and others (1988), Thordarson and others (1967), Winograd and Thordarson (1975), or were derived from drillers' logs or well-completion reports that describe geology in the boreholes, open intervals in the wells, and measurements of depth to water.

\section{GROUND-WATER LEVELS}

Ground-water levels are reported as depths to water and ground-water altitudes. Depth to water is the difference between land surface and the water level in a well. Groundwater altitude is the difference between the water level in a well and a common datum. The National Geodetic Vertical Datum of 1929 is the common datum in this report.

Depth to water is measured directly from a stable reference that is called the measuring point. Depth-to-water below a measuring point commonly is measured with a steel tape, an electric tape, or a pressure transducer. Measuring points typically are a notch in the well casing, but can be the top of a bolt as at Devils Hole (AM-4). Depth to water is computed by subtracting the height of a measuring point above land surface from the depthto-water below a measuring point.

Ground-water altitude is the difference between altitude of the measuring point and depth-to-water below the measuring point. The altitudes of all measuring points were surveyed. Ground-water altitude is reported to indicate the general direction of ground-water flow.

Accuracy of depths to water and altitudes of the water surface contained in this report are variable. Inaccuracies are largely dependent on heights of measuring points above land surface and altitudes of benchmarks that are used as starting points for surveys. Deviations of boreholes from vertical also affect accuracy of measurements. Deviations from vertical were estimated to be about $0.4 \mathrm{ft}$ at sites near Yucca Mountain (Boucher, 1994b).

Precision of depths to water, however, can be used to detect changing conditions through time and is indicated by repeatability of measurements. Data recorded in the field during 2003 indicate that repeatability ranges from 0.00 to $0.05 \mathrm{ft}$, but generally is less than or equal to $0.02 \mathrm{ft}$ for calibrated electric tapes and steel tapes. Precision of data collected by other agencies using uncalibrated electric tapes was assumed to be comparable. Overall, precision of water levels contained in this report are estimated to be less than or equal to $0.05 \mathrm{ft}$.

\section{Electric Tape}

Electric tapes used by USGS-EMP personnel were marked with a unique identifier for quality-assurance purposes and calibrated using reference steel tapes (which served as accepted representations of depth to water below the measuring point). At depths greater than $500 \mathrm{ft}$, the electric tapes were calibrated using the HRC 2,800-ft reference steel tape or the USGS-EMP calibrated steel tape (chain \#5). At depths less than $500 \mathrm{ft}$, the electric tapes were calibrated using a steel tape maintained by EMP personnel and identified as the 500-ft reference steel tape $\# 1$.

HRC 2,800-ft reference steel tape measurements are adjusted to account for mechanical stretch and thermal expansion of the tape. USGS-EMP chain \#5 measurements are adjusted to account for differences between the HRC reference and USGS-EMP chain \#5. No adjustments were necessary for the USGS-EMP 500-ft reference steel tape \#1 because mechanical stretch and thermal expansion of the tape are considered negligible at the depths to water measured. 
Table 1. Index to monitoring sites in Yucca Mountain region, 2003

Site number: Alphanumeric identifier used to identify sites on maps and tables. First part represents hydrographic area in which sites is located. Hydrographic areas: CF, Crater Flat; JF or J, Jackass Flats; RV, Rock Valley; MV, Mercury Valley; AD or AM, Amargosa Desert; DV, Death Valley. Second part is sequential numbering representing relative location of site within hydrographic area or Ash Meadows spring-discharge area; numbering order generally is north to south, then west to east. Sites J-13, J-11, and J-12 previously were numbered by Raytheon Services Nevada and herein were not renumbered.

U.S. Geological Survey site identification: Unique identification number for sites as stored in files and data bases of U.S. Geological Survey.

Latitude and longitude: Referenced to North American Datum of 1927.

Local site number: Alphanumeric identifier based on location of site within hydrographic areas and rectangular subdivisions of public lands.

Referenced to Mount Diablo base line and meridian for sites in Nevada or San Bernardino base line and meridian for sites in California (U.S. Geological Survey, 1986a, b).

Owner: Acronyms listed for sites owned by Federal agencies: BLM, Bureau of Land Management; DOE, U.S. Department of Energy; NPS, National Park Service; USFWS, U.S. Fish and Wildlife Service; USGS, U.S. Geological Survey.

Data type: Type of data included in this report. D, ground-water discharge; L, ground-water level.

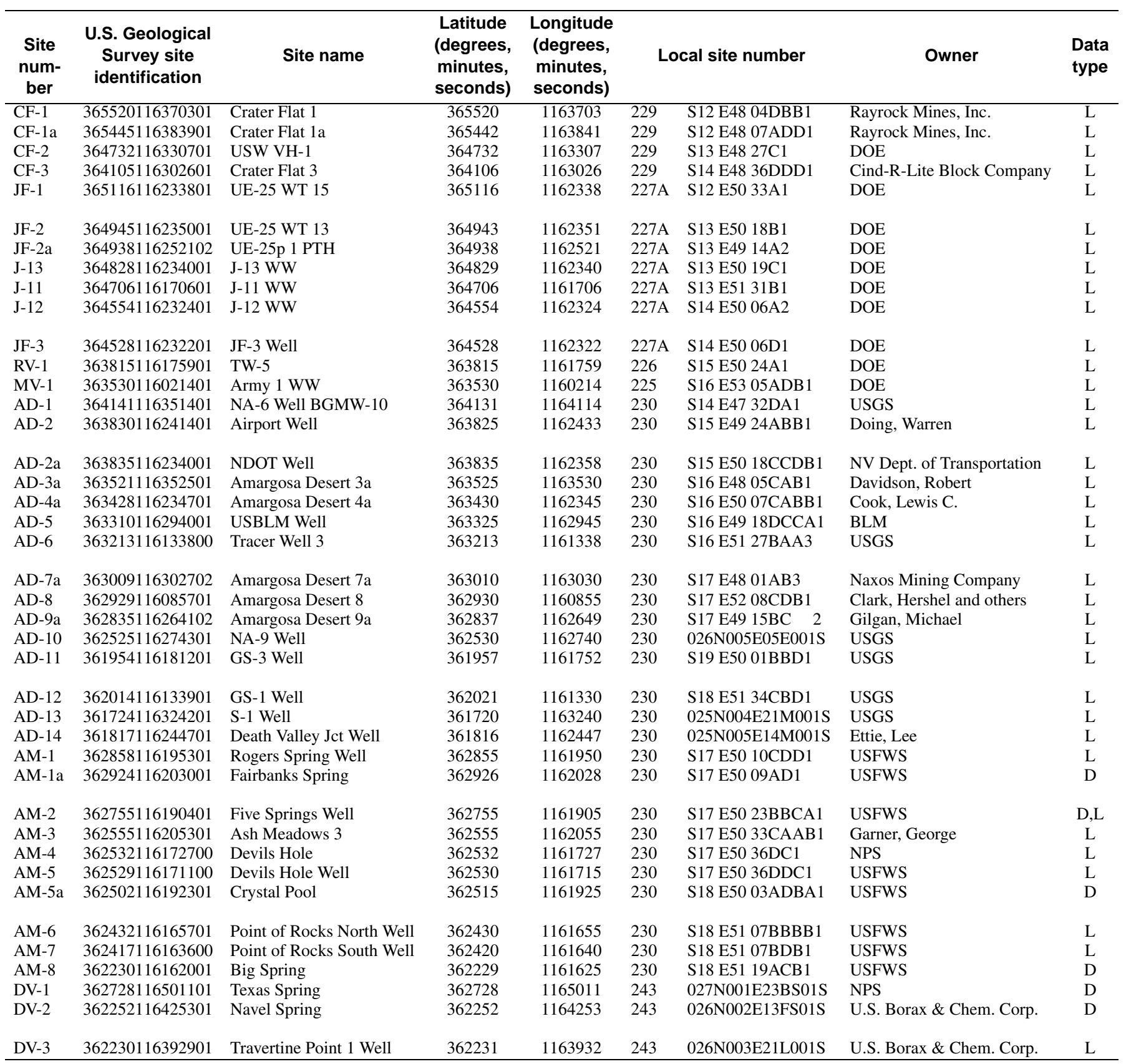


Site number: Alphanumeric identifier used to identify sites on maps and tables. First part represents hydrographic area in which site is located. Hydrographic areas: CF, Crater Flat; JF or J, Jackass Flats; RV, Rock Valley; MV, Mercury Valley; AD or AM, Amargosa Desert; DV, Death Valley. Second part is sequential numbering representing relative location of site within hydrographic area or Ash Meadows spring-discharge area; numbering order generally is north to south, then west to east. Sites J-13, J-11, and J-12 previously were numbered by Raytheon Services Nevada and herein were not renumbered.

U.S. Geological Survey site identification: Unique identification number for site as stored in files and databases of U.S. Geological Survey (USGS).

Accessible well depth: Well depths listed are as reported in sources listed in explanation for Data source (see below) or as measured by USGS personnel (noted with 's').

Casing diameter at land surface: Outside casing diameter of segment most prominent at land surface; rounded to nearest inch.

Top of open interval: Depth to top part(s) of well that can receive ground water from lithologic interval. Uncased borehole is designated open interval in this table. Open interval may be deeper than accessible well depth, which may reflect original drilled depth. As reported in sources listed in explanation for Data source (see below). U, unknown, no data.

Bottom of open interval: Depth to bottom part(s) of well that can receive ground water from lithologic interval. Uncased borehole is designated open interval in this table. Open interval may be deeper than accessible well depth, which may reflect original drilled depth. As reported in sources listed in explanation for Data source (see below). U, unknown, no data.

Diameter of open interval: Inside casing diameter; rounded to nearest inch. Hole diameter is listed where no casing is present. U, unknown, no data.

Type of open interval: Description of open interval. P, perforated or slotted casing; S, screened casing, type not known; U, unknown, no data; X, uncased borehole.

Data source: Source of information on well depth and open intervals. D, Well-driller's log, well-completion report, or Fenix \& Scisson, Inc., or Raytheon Services Nevada hole-history data; J, Johnston (1968); M, no source, data not available; O, Owner of well; R, Robison and others (1988); T, Thordarson and others (1967).

Contributing units: Saturated lithologic interval yielding water to well. C, carbonate rock; F, valley fill; S, undifferentiated sedimentary rock; V, volcanic rock

\begin{tabular}{|c|c|c|c|c|c|c|c|c|c|c|}
\hline \multirow{3}{*}{$\begin{array}{c}\text { Site } \\
\text { number } \\
\text { (fig. 1) }\end{array}$} & \multirow{3}{*}{$\begin{array}{l}\text { U.S. Geological } \\
\text { Survey site } \\
\text { identification }\end{array}$} & \multirow{3}{*}{ Site name } & \multirow{3}{*}{$\begin{array}{c}\text { Accessible } \\
\text { well depth } \\
\text { (feet below } \\
\text { land } \\
\text { surface) }\end{array}$} & \multirow{3}{*}{$\begin{array}{l}\text { Casing } \\
\text { diameter } \\
\text { at land } \\
\text { surface } \\
\text { (inches) }\end{array}$} & \multicolumn{4}{|c|}{ Open interval } & \multirow{3}{*}{$\begin{array}{l}\text { Data } \\
\text { source }\end{array}$} & \multirow{3}{*}{$\begin{array}{c}\text { Contributing } \\
\text { units }\end{array}$} \\
\hline & & & & & \multicolumn{2}{|c|}{$\begin{array}{c}\text { Feet below land } \\
\text { surface }\end{array}$} & \multirow{2}{*}{$\begin{array}{l}\text { Diameter } \\
\text { (inches) }\end{array}$} & \multirow[t]{2}{*}{ Type } & & \\
\hline & & & & & Top & Bottom & & & & \\
\hline CF-1 & 365520116370301 & Crater Flat 1 & 1,600 & 15 & 800 & 1,600 & 10 & $\mathrm{P}$ & $\mathrm{D}$ & $\mathrm{V}$ \\
\hline CF-1a & 365445116383901 & Crater Flat 1a & 700 & 7 & $\begin{array}{l}208 \\
513 \\
658\end{array}$ & $\begin{array}{l}313 \\
618 \\
700\end{array}$ & $\begin{array}{l}6 \\
6 \\
6\end{array}$ & $\begin{array}{l}\mathrm{P} \\
\mathrm{P} \\
\mathrm{P}\end{array}$ & $\mathrm{D}$ & $\mathrm{S}$ \\
\hline CF-2 & 364732116330701 & USW VH-1 & 2,501 & 10 & $\begin{array}{l}911 \\
912\end{array}$ & $\begin{array}{r}912 \\
2,501\end{array}$ & $\begin{array}{l}9 \\
6\end{array}$ & $\begin{array}{l}X \\
X\end{array}$ & $\mathrm{R}$ & $\mathrm{V}$ \\
\hline CF-3 & 364105116302601 & Crater Flat 3 & 460 & 9 & 320 & 460 & 8 & $\mathrm{P}$ & $\mathrm{D}$ & $\mathrm{F}$ \\
\hline JF-1 & 365116116233801 & UE-25 WT 15 & 1,360 & 11 & $\begin{array}{l}127 \\
130\end{array}$ & $\begin{array}{r}130 \\
1,360\end{array}$ & $\begin{array}{r}15 \\
9\end{array}$ & $\begin{array}{l}X \\
X\end{array}$ & $\mathrm{D}$ & V \\
\hline $\mathrm{JF}-2$ & 364945116235001 & UE-25 WT 13 & 1,160 & 11 & $\begin{array}{r}222 \\
224 \\
1,150\end{array}$ & $\begin{array}{r}224 \\
1,150 \\
1,160\end{array}$ & $\begin{array}{r}15 \\
9 \\
8\end{array}$ & $\begin{array}{l}X \\
X \\
X\end{array}$ & $\mathrm{D}$ & $\mathrm{V}$ \\
\hline
\end{tabular}


Table 2. Well-completion data at monitoring sites in Yucca Mountain region-Continued

\begin{tabular}{|c|c|c|c|c|c|c|c|c|c|c|}
\hline \multirow{3}{*}{$\begin{array}{c}\text { Site } \\
\text { number } \\
\text { (fig. 1) }\end{array}$} & \multirow{3}{*}{$\begin{array}{l}\text { U.S. Geological } \\
\text { Survey site } \\
\text { identification }\end{array}$} & \multirow{3}{*}{ Site name } & \multirow{3}{*}{$\begin{array}{c}\text { Accessible } \\
\text { well depth } \\
\text { (feet below } \\
\text { land } \\
\text { surface) }\end{array}$} & \multirow{3}{*}{$\begin{array}{l}\text { Casing } \\
\text { diameter } \\
\text { at land } \\
\text { surface } \\
\text { (inches) }\end{array}$} & \multicolumn{4}{|c|}{ Open interval } & \multirow{3}{*}{$\begin{array}{l}\text { Data } \\
\text { source }\end{array}$} & \multirow{3}{*}{$\begin{array}{c}\text { Contributing } \\
\text { units }\end{array}$} \\
\hline & & & & & \multicolumn{2}{|c|}{$\begin{array}{c}\text { Feet below land } \\
\text { surface }\end{array}$} & \multirow{2}{*}{$\begin{array}{l}\text { Diameter } \\
\text { (inches) }\end{array}$} & \multirow{2}{*}{ Type } & & \\
\hline & & & & & Top & Bottom & & & & \\
\hline JF-2a & 364938116252102 & UE-25p 1 PTH & 5,923 & 24 & $\begin{array}{l}4,256 \\
4,279 \\
5,900\end{array}$ & $\begin{array}{l}4,279 \\
5,900 \\
5,923\end{array}$ & $\begin{array}{r}10 \\
7 \\
6\end{array}$ & $\begin{array}{l}X \\
X \\
X\end{array}$ & $\mathrm{R}$ & $\mathrm{C}$ \\
\hline $\mathrm{J}-13$ & 364828116234001 & $\mathrm{~J}-13 \mathrm{WW}$ & 3,488 & 13 & $\begin{array}{r}996 \\
1,301 \\
2,690 \\
3,385\end{array}$ & $\begin{array}{l}1,301 \\
1,386 \\
3,312 \\
3,488\end{array}$ & $\begin{array}{r}13 \\
11 \\
5 \\
8\end{array}$ & $\begin{array}{l}\mathrm{P} \\
\mathrm{P} \\
\mathrm{P} \\
\mathrm{X}\end{array}$ & $\mathrm{T}$ & $\mathrm{V}$ \\
\hline $\mathrm{J}-11$ & 364706116170601 & $\mathrm{~J}-11 \mathrm{WW}$ & 1,327 & 13 & $\begin{array}{l}1,075 \\
1,242\end{array}$ & $\begin{array}{l}1,095 \\
1,298\end{array}$ & $\begin{array}{l}12 \\
12\end{array}$ & $\begin{array}{l}\mathrm{P} \\
\mathrm{P}\end{array}$ & $\mathrm{D}$ & $\mathrm{V}$ \\
\hline $\mathrm{J}-12$ & 364554116232401 & $\mathrm{~J}-12 \mathrm{WW}$ & 1,139 & 13 & $\begin{array}{l}793 \\
887\end{array}$ & $\begin{array}{r}868 \\
1,139\end{array}$ & $\begin{array}{l}12 \\
12\end{array}$ & $\begin{array}{l}\mathrm{P} \\
\mathrm{X}\end{array}$ & $\mathrm{D}$ & $\mathrm{V}$ \\
\hline JF-3 & 364528116232201 & JF- 3 Well & 1,138 & 9 & 735 & 1,138 & 8 & $\mathrm{P}$ & $\mathrm{D}$ & $\mathrm{V}$ \\
\hline RV-1 & 363815116175901 & TW- 5 & $800 \mathrm{~s}$ & 7 & $\begin{array}{l}735 \\
800\end{array}$ & $\begin{array}{l}800 \\
916\end{array}$ & $\begin{array}{c}6 \\
\mathrm{U}\end{array}$ & $\begin{array}{l}\mathrm{P} \\
\mathrm{X}\end{array}$ & $\mathrm{T}$ & $\mathrm{S}$ \\
\hline MV-1 & 363530116021401 & Army $1 \mathrm{WW}$ & 1,953 & 11 & $\begin{array}{r}800 \\
1,368 \\
1,370 \\
1,684\end{array}$ & $\begin{array}{l}1,050 \\
1,370 \\
1,684 \\
1,953\end{array}$ & $\begin{array}{r}11 \\
10 \\
9 \\
7\end{array}$ & $\begin{array}{l}P \\
X \\
X \\
X\end{array}$ & $\mathrm{D}$ & $\mathrm{C}$ \\
\hline AD-1 & 364141116351401 & NA-6 Well BGMW-10 & 960 & 2 & 930 & 940 & 2 & $\mathrm{~S}$ & $\mathrm{D}$ & $\mathrm{F}$ \\
\hline AD-2 & 363830116241401 & Airport Well & $750 \mathrm{~s}$ & 14 & 360 & 777 & 14 & $\mathrm{P}$ & $\mathrm{D}$ & $\mathrm{F}$ \\
\hline $\mathrm{AD}-2 \mathrm{a}$ & 363835116234001 & NDOT Well & 495 & 9 & 395 & 495 & 8 & $\mathrm{P}$ & $\mathrm{D}$ & $\mathrm{F}$ \\
\hline $\mathrm{AD}-3 \mathrm{a}$ & 363521116352501 & Amargosa Desert 3a & $240 \mathrm{~s}$ & 16 & 120 & 250 & 15 & $\mathrm{P}$ & $\mathrm{D}$ & $\mathrm{F}$ \\
\hline AD-4a & 363428116234701 & Amargosa Desert 4a & $269 \mathrm{~s}$ & 13 & $\begin{array}{l}147 \\
238\end{array}$ & $\begin{array}{l}213 \\
286\end{array}$ & $\begin{array}{l}12 \\
12\end{array}$ & $\begin{array}{l}\mathrm{P} \\
\mathrm{P}\end{array}$ & $\mathrm{D}$ & $\mathrm{F}$ \\
\hline AD-5 & 363310116294001 & USBLM Well & $348 \mathrm{~s}$ & 12 & $\mathrm{U}$ & $\mathrm{U}$ & $\mathrm{U}$ & $\mathrm{U}$ & M & $\mathrm{F}$ \\
\hline AD-6 & 363213116133800 & Tracer Well 3 & $678 \mathrm{~s}$ & 9 & 620 & 807 & 6 & $\mathrm{X}$ & $\mathrm{J}$ & $\mathrm{C}$ \\
\hline $\mathrm{AD}-7 \mathrm{a}$ & 363009116302702 & Amargosa Desert 7a & 210 & 7 & $\mathrm{U}$ & $\mathrm{U}$ & $\mathrm{U}$ & $\mathrm{U}$ & $\mathrm{O}$ & $\mathrm{F}$ \\
\hline
\end{tabular}




\begin{tabular}{|c|c|c|c|c|c|c|c|c|c|c|}
\hline \multirow{3}{*}{$\begin{array}{c}\text { Site } \\
\text { number } \\
\text { (fig. 1) }\end{array}$} & \multirow{3}{*}{$\begin{array}{l}\text { U.S. Geological } \\
\text { Survey site } \\
\text { identification }\end{array}$} & \multirow{3}{*}{ Site name } & \multirow{3}{*}{$\begin{array}{c}\text { Accessible } \\
\text { well depth } \\
\text { (feet below } \\
\text { land } \\
\text { surface) }\end{array}$} & \multirow{3}{*}{$\begin{array}{c}\text { Casing } \\
\text { diameter } \\
\text { at land } \\
\text { surface } \\
\text { (inches) }\end{array}$} & \multicolumn{4}{|c|}{ Open interval } & \multirow{3}{*}{$\begin{array}{l}\text { Data } \\
\text { source }\end{array}$} & \multirow{3}{*}{$\begin{array}{l}\text { Contributing } \\
\text { units }\end{array}$} \\
\hline & & & & & \multicolumn{2}{|c|}{$\begin{array}{l}\text { Feet below land } \\
\text { surface }\end{array}$} & \multirow{2}{*}{$\begin{array}{l}\text { Diameter } \\
\text { (inches) }\end{array}$} & \multirow{2}{*}{ Type } & & \\
\hline & & & & & Top & Bottom & & & & \\
\hline AD-8 & 362929116085701 & Amargosa Desert 8 & $215 \mathrm{~s}$ & 15 & $\mathrm{U}$ & $\mathrm{U}$ & $\mathrm{U}$ & $\mathrm{U}$ & M & $\mathrm{F}$ \\
\hline AD-9a & 362835116264102 & Amargosa Desert 9a & 415 & 10 & $\begin{array}{r}55 \\
200\end{array}$ & $\begin{array}{l}200 \\
515\end{array}$ & $\begin{array}{l}10 \\
10\end{array}$ & $\begin{array}{l}\mathrm{P} \\
\mathrm{X}\end{array}$ & $\mathrm{D}$ & $\mathrm{F}$ \\
\hline $\mathrm{AD}-10$ & 362525116274301 & NA-9 Well & 1,090 & 2 & 1,063 & 1,066 & 2 & $\mathrm{~S}$ & $\mathrm{D}$ & $\mathrm{F}$ \\
\hline AD-11 & 361954116181201 & GS-3 Well & 2,000 & 2 & 1,969 & 1,979 & 2 & $\mathrm{~S}$ & $\mathrm{D}$ & $\mathrm{F}$ \\
\hline $\mathrm{AD}-12$ & 362014116133901 & GS-1 Well & 1,580 & 2 & 1,549 & 1,559 & 2 & $\mathrm{~S}$ & $\mathrm{D}$ & $\mathrm{F}$ \\
\hline AD-13 & 361724116324201 & S-1 Well & 2,000 & 2 & 1,969 & 1,979 & 2 & $\mathrm{~S}$ & $\mathrm{D}$ & $\mathrm{F}$ \\
\hline AD-14 & 361817116244701 & Death Valley Jct Well & $225 \mathrm{~s}$ & 12 & 160 & 200 & 12 & $\mathrm{~S}$ & $\mathrm{D}$ & $\mathrm{F}$ \\
\hline AM-1 & 362858116195301 & Rogers Spring Well & $202 \mathrm{~s}$ & 16 & $\begin{array}{l}100 \\
240\end{array}$ & $\begin{array}{l}240 \\
420\end{array}$ & $\begin{array}{l}12 \\
16\end{array}$ & $\begin{array}{l}\mathrm{P} \\
\mathrm{X}\end{array}$ & $\mathrm{D}$ & $\mathrm{F}$ \\
\hline AM-2 & 362755116190401 & Five Springs Well & $123 \mathrm{~s}$ & 14 & $\begin{array}{r}0 \\
100\end{array}$ & $\begin{array}{l}100 \\
140\end{array}$ & $\begin{array}{l}13 \\
14\end{array}$ & $\begin{array}{l}\mathrm{P} \\
\mathrm{X}\end{array}$ & $\mathrm{D}$ & $\mathrm{C}$ \\
\hline AM-3 & 362555116205301 & Ash Meadows 3 & $202 \mathrm{~s}$ & 9 & 140 & 180 & 8 & $\mathrm{P}$ & $\mathrm{O}$ & $\mathrm{F}$ \\
\hline AM-5 & 362529116171100 & Devils Hole Well & $200 \mathrm{~s}$ & 16 & 48 & 248 & 16 & $\mathrm{P}$ & $\mathrm{D}$ & $\mathrm{F}$ \\
\hline AM-6 & 362432116165701 & Point of Rocks North Well & 500 & 16 & 139 & 500 & 16 & $\mathrm{P}$ & $\mathrm{D}$ & $\mathrm{F}$ \\
\hline AM-7 & 362417116163600 & Point of Rocks South Well & $586 \mathrm{~s}$ & 14 & $\begin{array}{l}132 \\
468\end{array}$ & $\begin{array}{l}467 \\
818\end{array}$ & $\begin{array}{c}14 \\
\mathrm{U}\end{array}$ & $\begin{array}{l}\mathrm{P} \\
\mathrm{X}\end{array}$ & $\mathrm{D}$ & $\mathrm{C}$ \\
\hline DV-3 & 362230116392901 & Travertine Point 1 Well & $650 \mathrm{~s}$ & 5 & 100 & 970 & 5 & $\mathrm{X}$ & $\mathrm{D}$ & C \\
\hline
\end{tabular}


A correction factor is the difference between the reference steel-tape measurement and uncorrected electric-tape measurement (table 3). Differences exist between the reference steel tape and the electric tape because of mechanical stretch, shrinkage caused by decreased elasticity, shortening caused by the presence of kinks or twists in tape, and incorrect marking. Correction factors are computed using calibration data and, although changes in factors probably are not linear, linear interpolations with depth and time were made between successive calibrations.

Calibrated electric tapes were used at wells when frequent repetitive measurements were required due to fluctuating water levels, when depths to water were greater than $500 \mathrm{ft}$ or when wet conditions inside a well prevented measurements using chalked steel tapes. At least two measurements are made during each site visit, and supplemental measurements are made if those two measured depths differ by more than $0.05 \mathrm{ft}$. If supplemental measurements indicate the difference is due to rapidly changing water levels, the initial measured depth and appropriate site status are recorded. Measurements using calibrated electric tapes are indicated by method "V" in table 5 (see Basic Data section of this report).

Personnel of the HRC also made water-level measurements using calibrated electric tapes at sites CF-2, JF-1, JF-2, $\mathrm{JF}-2 \mathrm{a}, \mathrm{J}-13, \mathrm{~J}-11$, and J-12. These data-collection activities are governed by formal, unpublished technical procedures associated with the Yucca Mountain Office of Repository Development. Water-level altitudes were provided by HRC personnel (H.S. Page, written communs., 2003, 2004) and converted to depth below land surface by subtracting those altitudes from altitude of the land surface.

Additionally, water-level measurements were made with various electric tapes by the USFWS at sites AM-5, AM-6, and AM-7 and by NDWR at site AD-7a. These measurements are indicated by method " $\mathrm{T}$ " in table 5 .

\section{Steel Tape}

In 2003, USGS-EMP personnel used one uniquely marked 300-ft steel tape (ST-7) and two 500-ft steel tapes (ST-9, ST-10) for measurements. These steel tapes were checked against the USGS-EMP 500-ft reference steel tape \#1 at several depths to water to verify their accuracy. No corrections were needed to the measurements made with these steel tapes.

USGS-EMP personnel make a minimum of two measurements during each site visit to verify the initial measurement. Supplemental measurements are made if the two measured depths differ by more than $0.05 \mathrm{ft}$. If supplemental measurements indicate the difference is due to fluctuating water levels, the initial measured depth and appropriate site status are recorded. Measurements using steel tapes are indicated by method "S" in table 5.
Table 3. Electric-tape calibration data used to derive correction factors, 2003

Uncorrected depth to water: Measured depth to water below measuring point using electric tape.

Device: Electric tape used to measure depth to water.

Correction factor: Difference between depth to water measurements using reference steel tape and electric tape.

\begin{tabular}{cccc}
\hline Date & $\begin{array}{c}\text { Uncorrected depth to } \\
\text { water, in feet }\end{array}$ & Device & $\begin{array}{c}\text { Correction } \\
\text { factor, in } \\
\text { feet }\end{array}$ \\
\hline $01-17-2003$ & 131.33 & YMP-13 & -0.03 \\
$10-14-2003$ & 133.98 & YMP-13 & -0.04 \\
$01-23-2004$ & 134.15 & YMP-13 & -0.04 \\
$01-23-2003$ & 368.67 & YMP-13 & -0.07 \\
$10-14-2003$ & 368.46 & YMP-13 & -0.13 \\
& & & \\
$01-23-2004$ & 368.58 & YMP-13 & -0.13 \\
$08-13-2002$ & 605.05 & YMP-13 & -0.15 \\
$01-23-2003$ & 605.14 & YMP-13 & -0.16 \\
$10-08-2003$ & 605.08 & YMP-13 & -0.21 \\
$02-04-2004$ & 605.12 & YMP-13 & -0.26 \\
& & & \\
$08-14-2002$ & 743.88 & YMP-13 & -0.24 \\
$01-22-2003$ & 743.96 & YMP-13 & -0.23 \\
$10-07-2003$ & 743.76 & YMP-13 & -0.33 \\
$02-04-2004$ & 743.82 & YMP-13 & -0.35 \\
& & & \\
$01-22-2003$ & 744.52 & PRT-4 & -0.79 \\
$02-04-2004$ & 744.39 & PRT-4 & -0.92 \\
$01-21-2003$ & $1,043.36$ & PRT-4 & -1.11 \\
$10-08-2003$ & $1,043.50$ & PRT-4 & -1.18 \\
$02-05-2004$ & $1,043.70$ & PRT-4 & -1.23 \\
& & & \\
$01-22-2003$ & $1,186.41$ & PRT-4 & -1.20 \\
$10-07-2003$ & $1,138.28$ & PRT-4 & -1.22 \\
$02-05-2004$ & $1,138.60$ & PRT-4 & -1.29 \\
$01-22-2003$ & $1,321.28$ & PRT-4 & -1.16 \\
$10-07-2003$ & $1,321.02$ & PRT-4 & -1.26 \\
\hline
\end{tabular}

HRC personnel also made a water-level measurement using a steel tape at site CF-2. This data-collection activity is governed by a formal, unpublished technical procedure associated with the Yucca Mountain Office of Repository Development. Water-level altitude was provided by HRC personnel (H.S. Page, written commun., 2004) and converted to depth below land surface by subtracting that altitude from altitude of the land surface.

\section{Pressure Sensor}

Two sites, JF-3 and AD-6, are instrumented by USGS-EMP to continually record ground-water level and atmospheric pressure at 15-minute intervals. Instrumentation includes a vented pressure sensor installed below the water surface, a barometer, and a data logger. Recorded data are processed to produce data on continual depth to water, atmospheric pressure, and daily average depth to water. (See tables 6 and 7 within Basic Data section of this report.) The pressure sensors at sites JF-3 and AD-6 transmit data to the data logger in units of pounds per square inch, which varies with the height of the water above the sensor. 
The sensor is calibrated for a range of depths that spans the anticipated range of water-level fluctuations. Water-level fluctuations are simulated by raising and lowering the pressure sensor. Raising the sensor $1 \mathrm{ft}$ will decrease the amount of submergence of the pressure sensor by $1 \mathrm{ft}$, thereby simulating a $1 \mathrm{ft}$ increase in depth to water. Lowering the sensor $1 \mathrm{ft}$ will increase the amount of submergence of the pressure sensor by $1 \mathrm{ft}$, thereby simulating a $1 \mathrm{ft}$ decrease in depth to water. Upon completion of pressure-sensor calibration, another water-level measurement is made with a calibrated steel or electric tape to check for fluctuation of the water level during calibration of the sensor.

Data recorded while calibrating the sensor are used to develop a regression equation to convert pressure readings to water level below land surface. The pressure readings from the data logger and corresponding simulated depths are regressed using pressure, in pounds per square inch, as the independent variable and depth below land surface, in feet, as the dependent variable.

Water-level measurements are made with a calibrated steel or electric tape when a continual monitoring site is visited. The data logger records the pressure-sensor reading at the time of the measurement. The reading is converted to depth to water using the established regression equation and recorded on a field sheet as computed water level. The steel tape or electric tape water-level measurement is used as a reference measurement and is compared to the computed value. Any difference between the reference measurement and computed value is applied as a correction to the continual record. The correction is determined by linearly interpolating the difference with time between consecutive visits to account for drift in pressure-sensor output.

The applicable period for using a particular regression equation usually corresponds with calibrations at the beginning and ending of that period. If the applicable period for a regression equation does not correspond with successive calibrations, a period is selected that minimizes differences between reference measurements made during site visits and computed water levels at dates intermediate to the two calibrations. Listed in table 4 are equations developed from pressure-sensor calibration data and differences between reference and computed water levels.

Sites JF-2 and JF-2a also were instrumented to continually collect water-level data by HRC personnel in 2001 and 2003, respectively. Data collection and processing of these data are governed by formal, unpublished technical procedures associated with the Yucca Mountain Office of Repository Development.

Some data presented in this report (some data prior to 1999 at site AM-4) also are on the basis of continually collected water levels. Daily mean water levels were reported by the NPS. Daily mean data, for each month with a complete daily mean record, were used to compute monthly average water levels. Monthly averages are reported for the $15^{\text {th }}$ of the month at that site and are noted with measurement method "A" (table 5) when instan- taneous measurements of depth to water were unavailable during that month.

\section{GROUND-WATER DISCHARGES}

Ground-water data collected and compiled as part of USGS-EMP are shown in figures 7-9 and listed in table 8 within the Basic Data section of this report. The accuracy of the measurements are related directly to the operational conditions of the equipment and to the environmental conditions at the time of measurement. Ground-water discharges are reported to two significant figures and ranged from $0.82 \mathrm{gal} / \mathrm{min}$ at site DV-2 to 3,000 gal/min at site AM-5a (table 8).

The most commonly used method for measuring discharge was the vertical-axis current meter, indicated by a " $\mathrm{C}$ " in table 8. Accuracy of these measurements are estimated to be poor, or no better than 15 percent of actual flow (Rantz and others, 1982, p. 179-180).

Some discharge values were determined by measuring the depth of water inside a flume and comparing that depth to an applicable stage-discharge relation for the flume. Where an instrument has been installed to continually record stage in a flume, mean discharges can be computed for specific periods. This method is indicated by a " $Z$ " in table 8 and was used for site DV-1, where monthly mean discharge (reported for the 15 th of the month) was computed on the basis of daily data collected by NPS. Accuracy of these measurements is estimated to be fair or within 15 percent of actual flow (U.S. Geological Survey, 2003, p. 21).

The volumetric method, indicated by a "V"in table 8, was used for measuring ground-water discharge from sites AM-2 and DV-2. A 5-gal or 4-L container was used to collect all discharge from the sites while a stopwatch was used to determine the amount of time the discharge was collected. The discharge rate is the volume of discharge collected divided by the elapsed time of collection. This method was repeated a minimum of three times and an average rate was computed for each site visit. Accuracy of these measurements is estimated to be good or within 10 percent of actual flow (U.S. Geological Survey, 2003, p. 21).

\section{GROUND-WATER WITHDRAWALS}

Withdrawals were estimated from data provided by NDWR, DOE, and the USGS-Hydrologic Resources Management Program. The majority of data sources report data in gallons and for consistency all withdrawals presented in tables and figures in this report are converted to units of millions of gallons. Estimated annual ground-water withdrawals are based solely on available data. Years during which no withdrawals from a specific area are indicated may reflect the unavailability of data rather than the absence of withdrawals (table 9). In these instances, withdrawal may be underestimated. 
Table 4. Summary of pressure-sensor calibrations and associated error at wells JF-3 and AD-6, 2003

[Symbol: >, greater than value indicated]

\begin{tabular}{|c|c|c|c|c|c|c|c|c|c|c|}
\hline \multirow{2}{*}{$\begin{array}{c}\text { Site } \\
\text { number } \\
\text { (see fig. 1) }\end{array}$} & \multirow{2}{*}{$\begin{array}{l}\text { Date of } \\
\text { collection }\end{array}$} & \multirow{2}{*}{$\begin{array}{l}\text { Regression equation }{ }^{1} \text {, } \\
\text { in feet below land surface }\end{array}$} & \multirow{2}{*}{$\begin{array}{l}\text { Coefficient of } \\
\text { determination }{ }^{2}\end{array}$} & \multirow{2}{*}{$\begin{array}{c}\text { Number } \\
\text { of } \\
\text { points }^{3}\end{array}$} & \multicolumn{2}{|c|}{ Equation applied } & \multicolumn{4}{|c|}{ Differences between measured and computed water levels ${ }^{4}$} \\
\hline & & & & & Begin date & End date & $\begin{array}{l}\text { Minimum, } \\
\text { in feet }\end{array}$ & Date & $\begin{array}{l}\text { Maximum, } \\
\text { in feet }\end{array}$ & Date \\
\hline JF-3 & $\begin{array}{l}01-15-2003 \\
01-15-2004\end{array}$ & $\begin{array}{l}\mathrm{WL}=(-2.323 \times \mathrm{PSI})+715.301 \\
\mathrm{WL}=(-2.328 \times \mathrm{PSI})+715.224\end{array}$ & $\begin{array}{l}>0.99 \\
>0.99\end{array}$ & $\begin{array}{l}11 \\
11\end{array}$ & $\begin{array}{l}01-01-2003 \\
04-28-2003\end{array}$ & $\begin{array}{l}04-28-2003 \\
12-31-2003\end{array}$ & $\begin{array}{l}-0.01 \\
0.00\end{array}$ & $\begin{array}{l}01-15-2003 \\
04-28-2003\end{array}$ & $\begin{array}{l}-0.06 \\
-0.04\end{array}$ & $\begin{array}{l}04-28-2003 \\
12-04-2003\end{array}$ \\
\hline \multirow[t]{2}{*}{ AD-6 } & $01-15-2003$ & $\mathrm{WL}=(-2.330 \times \mathrm{PSI})+48.912$ & $>0.99$ & 13 & $01-01-2003$ & $08-28-2003$ & 0.01 & $\begin{array}{c}01-15-2003 \text { and } \\
02-06-2003\end{array}$ & 0.05 & $08-28-2003$ \\
\hline & 01-16-2004 & $\mathrm{WL}=(-2.310 \times \mathrm{PSI})+48.921$ & $>0.99$ & 13 & $08-28-2003$ & $12-31-2003$ & 0.01 & $12-05-2003$ & -0.02 & $\begin{array}{c}08-28-2003 \text { and } \\
09-16-2003 \\
\end{array}$ \\
\hline
\end{tabular}

${ }^{1}$ Equation developed to convert pressure readings (PSI) recorded by onsite instrumentation to water level in feet below land surface (WL).

${ }^{2}$ Value representing variation in water level that can be explained by variation in pressure. A value of 1.00 implies all variations in water level can be explained by variations in pressure.

${ }^{3}$ Number of pressure-sensor depths used to develop regression equation during calibration procedure.

${ }^{4}$ Differences between periodic water levels determined using electric or steel tapes and computed water levels determined by use of regression equation. 
Estimated ground-water withdrawals for calendar year 2003 are listed by hydrographic area (Amargosa Desert, Crater Flat, Jackass Flats, and Mercury Valley) within the Alkali FlatFurnace Creek Ranch and the Ash Meadows ground-water subbasins. The Amargosa Desert spans both subbasins and is further subdivided into two areas within the Ash Meadows ground-water subbasin. Because of recently available information, withdrawals for some years prior to 2003 have been revised (Karl Eitenmiller, Nevada Department of Water Resources, written commun., 2004; U.S. Geological Survey, 2004).

Withdrawals for irrigation use account for the majority of pumpage in the study area. Those withdrawals commonly are estimated by multiplying irrigated acreages by water-application rates. Irrigated acreage in the Amargosa Desert during 2003 , provided by the NDWR, was about 2,390 acres. The Amargosa Desert within the Alkali Flat-Furnace Creek Ranch subbasin has 2,388 acres and the Ash Meadows subbasin has 2 acres. Application rates used by the NDWR in 2003 averaged about 4 acre-ft/acre but estimates of application rates in the Amargosa Desert by Moreo and others (2003) ranged from 2 to 12 acre-ft/acre and averaged about 7 acre-ft/acre.

Withdrawals for domestic use account for the least pumpage in the study area. Reported domestic use is based on the number and location of wells drilled for domestic purposes (Robert Coache, Nevada Division of Water Resources, oral commun., 2004).

Ground-water withdrawal sites and general areas of ground-water withdrawals during 2003 are shown in figure 10. General areas of ground-water withdrawals are townships and ranges or are portions of townships and ranges in which the majority of ground-water withdrawals occurred.

\section{Withdrawals from Alkali Flat-Furnace Creek Ranch Ground-Water Subbasin}

Withdrawals from the Amargosa Desert hydrographic area within the Alkali Flat-Furnace Creek Ranch ground-water subbasin $(4,405 \mathrm{Mgal})$ were recompiled from a ground-water pumpage inventory made by NDWR for the entire Amargosa Desert. The pumpage inventory in 2003 includes estimated withdrawals for irrigation, mining, quasi-municipal and commercial, and domestic uses. Most reported withdrawals for the Amargosa Desert are from the Alkali Flat-Furnace Creek Ranch ground-water subbasin. Within this subbasin, groundwater withdrawals in the Amargosa Desert were used for irrigation (77 percent), mining (9 percent), quasi-municipal or commercial (11 percent), and domestic use (3 percent).

Withdrawals from Crater Flat of about 14.4 Mgal in 2003 were determined from flowmeters at well USW VH-2 and at sites CF-2 and CF-3. Estimated withdrawals for well USW VH-2 (about 9 Mgal) and site CF-3 (about 5 Mgal) are from NDWR (Karl Eitenmiller, written commun., 2004). Total withdrawals in 2003 for site CF-2 (less than 1 Mgal) are from DOE (Karen Bull, Bechtel SAIC Company, LLC, written commun.,
2004). Withdrawals from sites CF- 1 and CF-1a during 2003 are estimated as zero based on observations during site visits. About $9 \mathrm{Mgal} / \mathrm{yr}$ were pumped from well USW VH-2 during 1996-2002 (Karl Eitenmiller, Nevada Department of Water Resources, written commun., 2004). This pumpage was not included in estimates of annual ground-water withdrawals from Crater Flat for 1996-2002 (La Camera and Locke, 1998;

La Camera and others, 1999; Locke, 2001a, 2001b; Locke and La Camera, 2003). Annual ground-water withdrawals from Crater Flat are summarized and supersede all previously published estimates (table 9).

Withdrawals from Jackass Flats were determined from flowmeters at sites J-13 and J-12 during 2003. Ground-water withdrawals from site $\mathrm{J}-12$ accounted for about 95 percent of the roughly $13.5 \mathrm{Mgal}$ total withdrawals from Jackass Flats. Withdrawals for 2003 at these sites were recompiled from flowmeter readings provided by Bechtel Nevada as part of the USGS-Hydrologic Resources Management Program. Some previously published estimates of annual ground-water withdrawals from Jackass Flats $(1959,1960,1962-67$, and 197882) have been revised after further review by personnel associated with that program (U.S. Geological Survey, 2004). Annual ground-water withdrawals from Jackass Flats are summarized and supersede all previously published estimates (table 9).

Withdrawals from Rock Valley are considered negligible. The valley is mostly within the Nevada Test Site, which limits public access and use. Within the valley, no known DOE water supply wells exist, no pumpage is reported by DOE, and only one well that is not pumped (site RV-1) is present in USGS or DOE data bases.

\section{Withdrawals from Ash Meadows Ground-Water Subbasin}

Withdrawals from Mercury Valley of about $51 \mathrm{Mgal}$ in 2003 were recompiled from flowmeter readings for site MV-1 and provided by Bechtel Nevada as part of the USGSHydrologic Resources Management Program. Some previously published estimates of annual ground-water withdrawals from Mercury Valley (1964, 1972-82, and 1999) have been revised after further review by personnel associated with that program (U.S. Geological Survey, 2004). Annual ground-water withdrawals from Mercury Valley are summarized and supersede all previously published estimates (table 9).

Withdrawals from the Amargosa Desert hydrographic area within the Ash Meadows ground-water subbasin also were recompiled from the ground-water pumpage inventory made by NDWR for the entire Amargosa Desert. In 2003, about 22 Mgal were withdrawn from the Amargosa Desert within the Ash Meadows ground-water subbasin. The Amargosa Desert within this subbasin has been divided into two areas to provide information on withdrawals in the immediate vicinity of the environmentally sensitive Ash Meadows area. These areas are identified in table 9 and figure 12 as the Amargosa Desert (excluding Ash Meadows area) and the Amargosa Desert (Ash Meadows 
area). No withdrawals for mining use (greater than $0.3 \mathrm{Mgal}$ ), and only minor withdrawals for irrigation use (less than $1 \mathrm{Mgal}$ ) or quasi-municipal use (less than $1 \mathrm{Mgal}$ ) were reported from these two areas. During 2003, withdrawals in the Amargosa Desert (excluding Ash Meadows area) include irrigation and quasi-municipal withdrawals from three wells in T. 17 S., R. 52 E. Also during 2003, withdrawals for quasi-municipal and commercial uses from the Amargosa Desert (Ash Meadows area) include withdrawals from two wells in T. 18 S., R. 50 E. Within Ash Meadows subbasin, withdrawals for domestic use in 2003 from the two areas were minor, about 13 and 2 percent, respectively, in comparison to total withdrawals for domestic use in the Amargosa Desert hydrographic area.

\section{PRESENTATION OF GROUND-WATER DATA}

Ground-water data listed in tables 5-9 have been collected and compiled in the Yucca Mountain region as part of this study and are shown in figures 2-9 and 11-12. The graphical groundwater data was selected from the tables in this and previously published reports for the Yucca Mountain region. Pumping water from or injecting water into a well or nearby well may result in short-term variations in water levels that differ from long-term or sustained ground-water levels. Such short-term variations are excluded from the figures showing variations in water levels through time. Observed differences among measurements could result from differing accuracies of equipment used, inaccurate readings of equipment, inaccurate reporting of measurements, or changes in personnel making measurements.

Table 5 lists periodic measurements of depth to water and water-level altitude for 2003 and figures 2-5 show measurements of water levels from the earliest available information through 2003. Periodic data usually are from manual onsite measurements of depth to water. Exceptions are water-level data noted with data source "HRC" or "NTS" and method "F," and water-level data noted with data source "NPS" and method "A" in table 5. These data were derived from measurements by onsite instrumentation. Table 5 also includes revised watersurface altitudes at Devils Hole (site AM-4) for May 20, 1992 through 2002. These altitudes followed replacement of the bolt on May 20, 1992, that serves as a measurement point and are on the basis of surveyed altitudes of the new measurement point during 1992-2002. All water-level data collected by other agencies or programs are subject to revision upon further review by that agency or program.

Listed in tables 6 and 7 are daily average water levels for sites JF-3 and AD-6, respectively, for 2003. Figure 6 shows daily average water levels at sites JF-3 and AD- 6 as listed in this and previous reports on selected ground-water data for the Yucca Mountain region.

Table 8 lists measurements of ground-water discharge for 2003 and figures 7-9 show measurements of ground-water discharge from the earliest available information through 2003.
Discharge measured at site AM-2 represents a combination of flow directly through slotted casing at land surface and leakage through the casing's annular space. The increased discharge at site AM-2 probably is attributable to clearing the uppermost portion of annular space surrounding the casing. Data for site DV-1 reported with data source "NPS" represent monthly average discharge collected from instrumentation operated by the NPS. Discharge data collected by other agencies or programs are subject to revision upon further review by that agency or program.

Table 9 lists estimates of ground-water withdrawals from wells in the Yucca Mountain region for 2003. Estimates of historical withdrawals in the region that are in addition to or have been revised are footnoted. Figure 10 shows general locations of ground-water withdrawals during 2003 and figures 11-12 show estimated withdrawals from wells from the earliest available information through 2003. Total bar heights shown in figures 11 and 12 equal the sum of withdrawals from all areas shown within the subbasin for a given year. Information on withdrawals provided by other agencies or programs is subject to revision upon further review by that agency or program.

\section{DISCUSSION OF GROUND-WATER LEVELS AND GROUND-WATER WITHDRAWALS IN JACKASS FLATS}

Figure 13 shows water-level altitudes for seven wells and estimated annual ground-water withdrawals in Jackass Flats from 1983 through 2003. For greater consistency and comparability of data, a water level in well J-12 that may have been affected by pumping ("P" in table 5) was excluded because it may reflect a short-term condition. Annual ground-water withdrawals in Jackass Flats prior to 1983 are excluded because those data generally represent only the withdrawals from well J-12 rather than total withdrawals from Jackass Flats.

Water-level altitudes (fig. 13) are based on periodic measurements contained in this and previously published reports or are daily average water levels provided by USGSSCP personnel. Lines are dashed when no data were available.

Ground-water withdrawals in Jackass Flats decreased from 17.7 Mgal in 2002 to $13.5 \mathrm{Mgal}$ in 2003 and consisted of combined pumpage from water-supply wells J-13 and J-12. Withdrawals during 2003 were about 24 percent less than withdrawals in 2002 and about 74 percent less than the median withdrawal of $52 \mathrm{Mgal}$ for the period 1983-91 (La Camera and Westenburg, 1994, p. 30). Median water-level altitudes in Jackass Flats usually corresponded with increases or decreases in withdrawals, although changes in water levels may be due to changes in recharge to the ground-water system rather than withdrawals (Fenelon and Moreo, 2002, p. 54-58). Groundwater withdrawals from well J-13 decreased from about 10.2 Mgal in 2002 to about $0.7 \mathrm{Mgal}$ in 2003. Ground-water withdrawals from well J-12 increased from about 7.5 Mgal in 2002 to $12.8 \mathrm{Mgal}$ in 2003 . 
Table 10 contains selected statistics for water-level altitudes in Jackass Flats. Data for wells JF-1, JF-2, JF-2a, J-13, $\mathrm{J}-11, \mathrm{~J}-12$, and JF-3 are summarized for a baseline period of 1992-93 and for subsequent calendar years through 2003. For each period, the table lists the number of measurements, minimum, maximum, and median water-level altitude, and the average deviation of water levels from the median water level. Only one measurement was available for site JF-2 in 2002, therefore, no statistics were determined for that year. Continual data for the period following 2001 that has been subsequently released can be obtained from HRC personnel. The period 1992-93 was selected as a baseline because it is the earliest period when data were available for all sites and data-collection frequency was roughly equivalent at any particular site during that time.

Median water-level altitudes indicate a statistically representative ground-water level for a particular time. Median water-level measurements are listed because the calculated median is less affected by a few high or low values than is the arithmetic mean.

The average deviation indicates the dispersion of individual measurements about the median; it provides an indication of how representative of a typical water-level altitude the median is during a particular period. The average deviation equals the sum of the absolute differences between individual measurements and the median, divided by the number of individual measurements. This measure of dispersion was selected rather than standard deviation because it can be used to describe dispersion about a median value rather than dispersion about an arithmetic mean.

Figure 14 shows the median water-level altitudes and the average deviation of the water levels for wells JF-1, JF-2, JF-2a, J-13, J-11, J-12, and JF-3 for 1992-93 and for subsequent years through 2003. Median annual ground-water withdrawal in Jackass Flats for 1992-93 and estimated annual withdrawals for subsequent years through 2003 also are included.

From 2002 to 2003, median water-level altitudes in six of seven wells in Jackass Flats increased from 0.1 to $0.5 \mathrm{ft}$. At one well in Jackass Flats (JF-2) a median water-level altitude was not calculated for 2002 because sufficient data were unavailable; from 2001 to 2003 the median water level decreased $0.2 \mathrm{ft}$. The median water-level altitudes at all monitoring wells in Jackass Flats in 2003 were greater (0.4-2.8 $\mathrm{ft}$ ) than their altitudes for the baseline period in 1992-93. These increases in median water-level altitudes exceeded historical variability in water levels exhibited during their baseline periods. Changes exceeding historical variability could be due to changes in monitoring instrumentation or frequency, limited lengths of historical baseline periods, withdrawals or recharge that differed from those during baseline periods, or a combination of effects.

\section{REFERENCES CITED}

Boucher, M.S., 1994a, Water levels in wells J-11 and J-12, 1989-91, Yucca Mountain area, Nevada: U.S. Geological Survey Open-File Report 94-303, 9 p.

Boucher, M.S., 1994b, Precision and accuracy of manual waterlevel measurements taken in the Yucca Mountain area, Nye County, Nevada, 1988-90: U.S. Geological Survey WaterResources Investigations Report 93-4025, 18 p.

Cardinalli, J.L., Roach, L.M., Rush, F.E., and Vasey, B.J., 1968, State of Nevada hydrographic areas: Nevada Division of Water Resources map, 1:500,000-scale.

Dudley, W.W., Jr., and Larson, J.D., 1976, Effect of irrigation pumping on desert pupfish habitats in Ash Meadows, Nye County, Nevada: U.S. Geological Survey Professional Paper 927, $52 \mathrm{p}$.

Fenelon, J.M., and Moreo, M.T., 2002, Trend analysis of ground-water levels and spring discharge in the Yucca Mountain region, Nevada and California, 1960-2000: U.S. Geological Survey Water-Resources Investigations Report 02-4178, $97 \mathrm{p}$.

Fenneman, N.M., 1931, Physiography of western United States: New York, McGraw-Hill, 534 p.

Gemmell, J.M., 1990, Water levels in periodically measured wells in the Yucca Mountain area, Nevada, 1988: U.S. Geological Survey Open-File Report 90-113, 47 p.

Graves, R.P., 1998, Water levels in the Yucca Mountain area, Nevada, 1996: U.S. Geological Survey Open-File Report 98-169, $81 \mathrm{p}$.

Graves, R.P., 2000, Water levels in the Yucca Mountain area, Nevada, 1997-98: U.S. Geological Survey Open-File Report 00-186, $81 \mathrm{p}$.

Graves, R.P., and Goemaat, R.L., 1998, Water levels in the Yucca Mountain area, Nevada, 1995: U.S. Geological Survey Open-File Report 97-101, 92 p.

Graves, R.P., Tucci, Patrick, and Goemaat, R.L., 1996, Water levels in the Yucca Mountain area, Nevada, 1994: U.S. Geological Survey Open-File Report 95-757, 101 p.

Hale, G.S., and Westenburg, C.L., 1995, Selected ground-water data for Yucca Mountain region, southern Nevada and eastern California, calendar year 1993: U.S. Geological Survey Open-File Report 95-158, 67 p.

Harrill, J.R., Gates, J.S., and Thomas, J.M., 1988, Major ground-water flow systems in the Great Basin region of Nevada, Utah, and adjacent states: U.S. Geological Survey Hydrologic Investigations Atlas HA-694-C, 2 sheets.

Johnston, R.H., 1968, U.S. Geological Survey tracer study, Amargosa Desert, Nye County, Nevada, Part 1, Exploratory drilling, tracer well construction and testing, and preliminary findings: U.S. Geological Survey Report USGS-474-98, 64 p. [Available only from National Technical Information Service, U.S. Department of Commerce, Springfield, VA 22161.] 
Kilroy, K.C., 1991, Ground-water conditions in Amargosa Desert, Nevada-California, 1952-87: U.S. Geological Survey Water-Resources Investigations Report 89-4101, $93 \mathrm{p}$.

La Camera, R.J., and Locke, G.L., 1998, Selected ground-water data for Yucca Mountain region, southern Nevada and eastern California, through December 1996: U.S. Geological Survey Open-File Report 97-821, 75 p.

La Camera, R.J., Locke, G.L., and Munson, R.H., 1999, Selected ground-water data for Yucca Mountain region, southern Nevada and eastern California, through December 1997: U.S. Geological Survey Open-File Report 98-628, $84 \mathrm{p}$.

La Camera, R.J., and Westenburg, C.L., 1994, Selected ground-water data for Yucca Mountain region, southern Nevada and eastern California, through December 1992: U.S. Geological Survey Open-File Report 94-54, 161 p.

La Camera, R.J., Westenburg, C.L., and Locke, G.L., 1996, Selected ground-water data for Yucca Mountain region, southern Nevada and eastern California, through December 1995: U.S. Geological Survey Open-File Report 96-553, $75 \mathrm{p}$.

Laczniak, R.J., Cole, J.C., Sawyer, D.A., and Trudeau, D.A., 1996, Summary of hydrogeologic controls on ground-water flow at the Nevada Test Site, Nye County, Nevada: U.S. Geological Survey Water-Resources Investigations Report 96-4109, 59 p.

Lobmeyer, D.H., Luckey, R.R., O'Brien, G.M., and Burkhardt, D.J., 1995, Water levels in continuously monitored wells in the Yucca Mountain area, Nevada, 1989: U.S. Geological Survey Open-File Report 93-98, 173 p.

Locke, G.L., 2001a, Selected ground-water data for Yucca Mountain region, southern Nevada and eastern California, through December 1998: U.S. Geological Survey Open-File Report 99-250, 88 p.

Locke, G.L., 2001b, Selected ground-water data for Yucca Mountain region, southern Nevada and eastern California, through December 1999: U.S. Geological Survey Open-File Report 00-479, 75 p.

Locke, G.L. and La Camera, R.J., 2003, Selected ground-water data for Yucca Mountain region, southern Nevada and eastern California, January 2000-December 2002: U.S. Geological Survey Open-File Report 03-387, 133 p.

Luckey, R.R., Lobmeyer, D.H., and Burkhardt, D.J., 1993, Water levels in continuously monitored wells in the Yucca Mountain area, Nevada, 1985-88: U.S. Geological Survey Open-File Report 91-493, 252 p.

McKinley, P.W., Long, M.P., and Benson, L.V., 1991, Chemical analysis of water from selected wells and springs in the Yucca Mountain area, Nevada and southeastern California: U.S. Geological Survey Open-File Report 90-355, 47 p.

Moreo, M.T., Halford, K.J., La Camera, R.J., and Laczniak, R.J., 2003, Estimated ground-water withdrawals from the Death Valley regional flow system, Nevada and California, 1913-98: U.S. Geological Survey Water-Resources
Investigations Report 03-4245, 28 p. Accessed on April 2004, at URL <http://water.usgs.gov/pubs/wri/wrir034245>.

O'Brien, G.M., 1991, Water levels in periodically measured wells in the Yucca Mountain area, Nevada, 1989: U.S. Geological Survey Open-File Report 91-178, 51 p.

O'Brien, G.M., 1993, Earthquake-induced water-level fluctuations at Yucca Mountain, Nevada, June 1992: U.S. Geological Survey Open-File Report 93-73, 12 p.

O'Brien, G.M., Tucci, Patrick, and Burkhardt, D.J., 1995, Water levels in the Yucca Mountain area, Nevada, 1992: U.S. Geological Survey Open-File Report 94-311, 74 p.

Rantz, S.E. and others, 1982, Measurement and computation of streamflow: Volume 1. Measurement of stage and discharge: U.S. Geological Survey Water-Supply Paper 2175, 284 p.

Robison, J.H., 1984, Ground-water level data and preliminary potentiometric-surface maps, Yucca Mountain and vicinity, Nye County, Nevada: U.S. Geological Survey Water-

Resources Investigations Report 84-4197, 8 p.

Robison, J.H., Stephens, D.M., Luckey, R.R., and Baldwin, D.A., 1988, Water levels in periodically measured wells in the Yucca Mountain area, Nevada, 1981-87: U.S. Geological Survey Open-File Report 88-468, 132 p.

Rush, F.E., 1968, Index of hydrographic areas in Nevada: Nevada Division of Water Resources, Information Report 6, $38 \mathrm{p}$.

Savard, C.S., 2001, Water levels in the Yucca Mountain area, Nevada, 1999: U.S. Geological Survey Open-File Report 01-343, $81 \mathrm{p}$.

Thordarson, William, Young, R.A., and Winograd, I.J., 1967, Records of wells and test holes in the Nevada Test Site and vicinity (through December 1966): U.S. Geological Survey Open-File Report TEI-872, 26 p.

Tucci, Patrick, and Burkhardt, D.J., 1995, Potentiometricsurface map, 1993, Yucca Mountain and vicinity, Nevada: U.S. Geological Survey Water-Resources Investigations Report 95-4149, 15 p.

Tucci, Patrick, Goemaat, R.L., and Burkhardt, D.J., 1996a, Water levels in the Yucca Mountain area, Nevada, 1993: U.S. Geological Survey Open-File Report 95-159, 94 p.

Tucci, Patrick, O’Brien, G.M., and Burkhardt, D.J., 1996b, Water levels in the Yucca Mountain area, Nevada, 1990-91: U.S. Geological Survey Open-File Report 94-111, 107 p.

U.S. Geological Survey, 1986a, Beatty, Nevada-California: U.S. Department of the Interior, U.S. Geological Survey, no. 36116-E1-TM-100, topographic map, 1:100 000-scale metric.

U.S. Geological Survey, 1986b, Death Valley Junction, California-Nevada: U.S. Department of the Interior, U.S. Geological Survey, no. 36116-A1-TM-100, topographic map, 1:100 000 -scale metric.

U.S. Geological Survey, 2003, Water-resources data Nevada water year 2002: U.S. Geological Survey Water-Data Report NV-02-1, 594 p.

U.S. Geological Survey, 2004, Water-Use Wells, Nevada Test Site and Vicinity: accessed on April 2004, at URL < http:// nevada.usgs.gov/doe_nv/wateruse/wumap.asp>. 
Waddell, R.K., Robison, J.H., and Blankennagel, R.K., 1984, Hydrology of Yucca Mountain and vicinity, Nevada-California-Investigative results through mid-1983: U.S. Geological Survey Water-Resources Investigations Report 84-4267, $72 \mathrm{p}$.

Westenburg, C.L., and La Camera, R.J., 1996, Selected ground-water data for Yucca Mountain region, southern Nevada and eastern California, through December 1994: U.S. Geological Survey Open-File Report 96-205, 73 p.
Winograd, I.J., and Thordarson, William, 1975, Hydrogeologic and hydrochemical framework, south-central Great Basin, Nevada-California, with special reference to the Nevada Test Site: U.S. Geological Survey Professional Paper 712-C, $126 \mathrm{p}$. 


\section{Basic Data}


18 Selected Ground-Water Data for Yucca Mountain Region, Southern Nevada and Eastern California, January-December 2003 


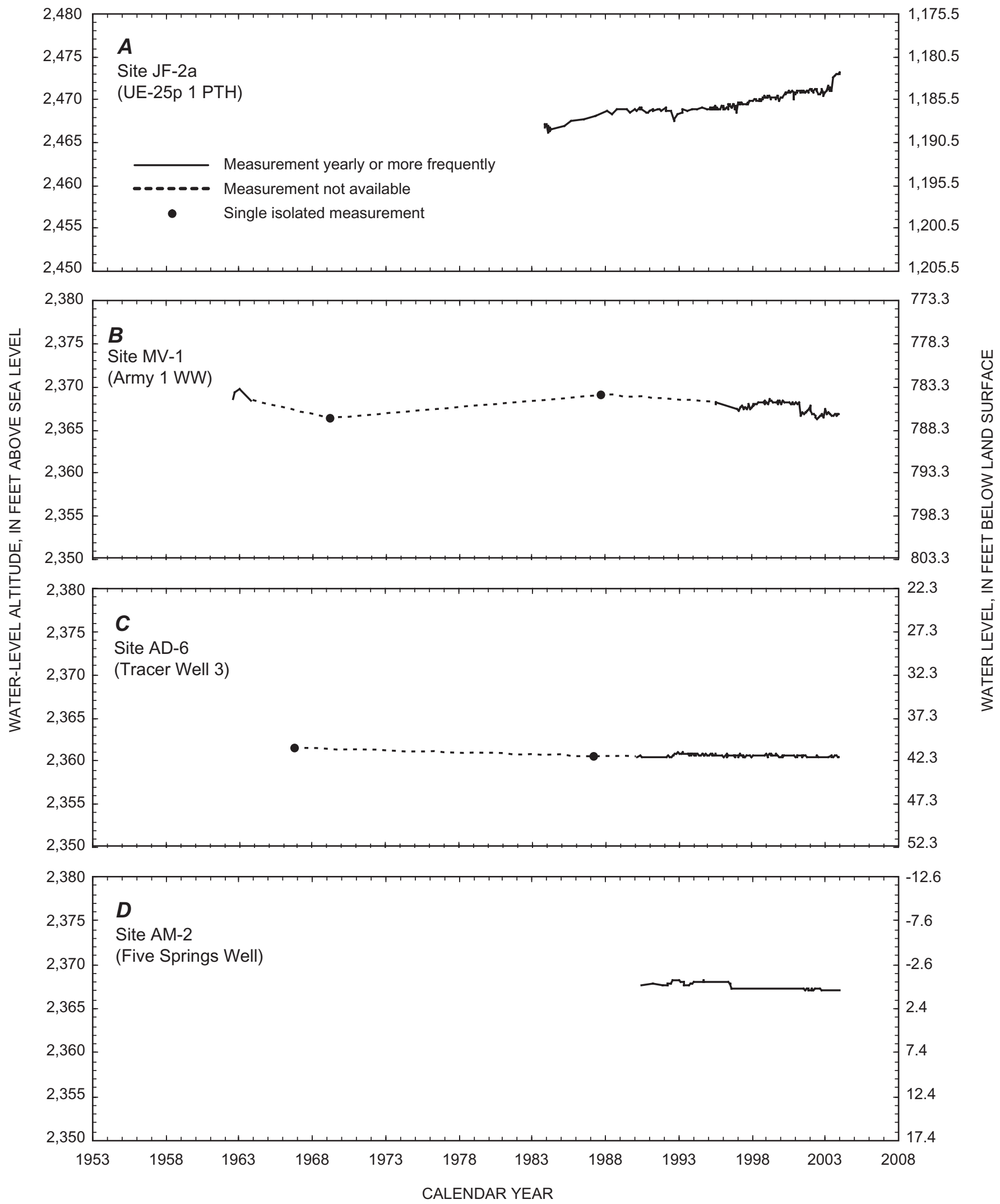

Figure 2. Periodic water levels for selected sites through 2003 at which primary contributing units are carbonate rock. 


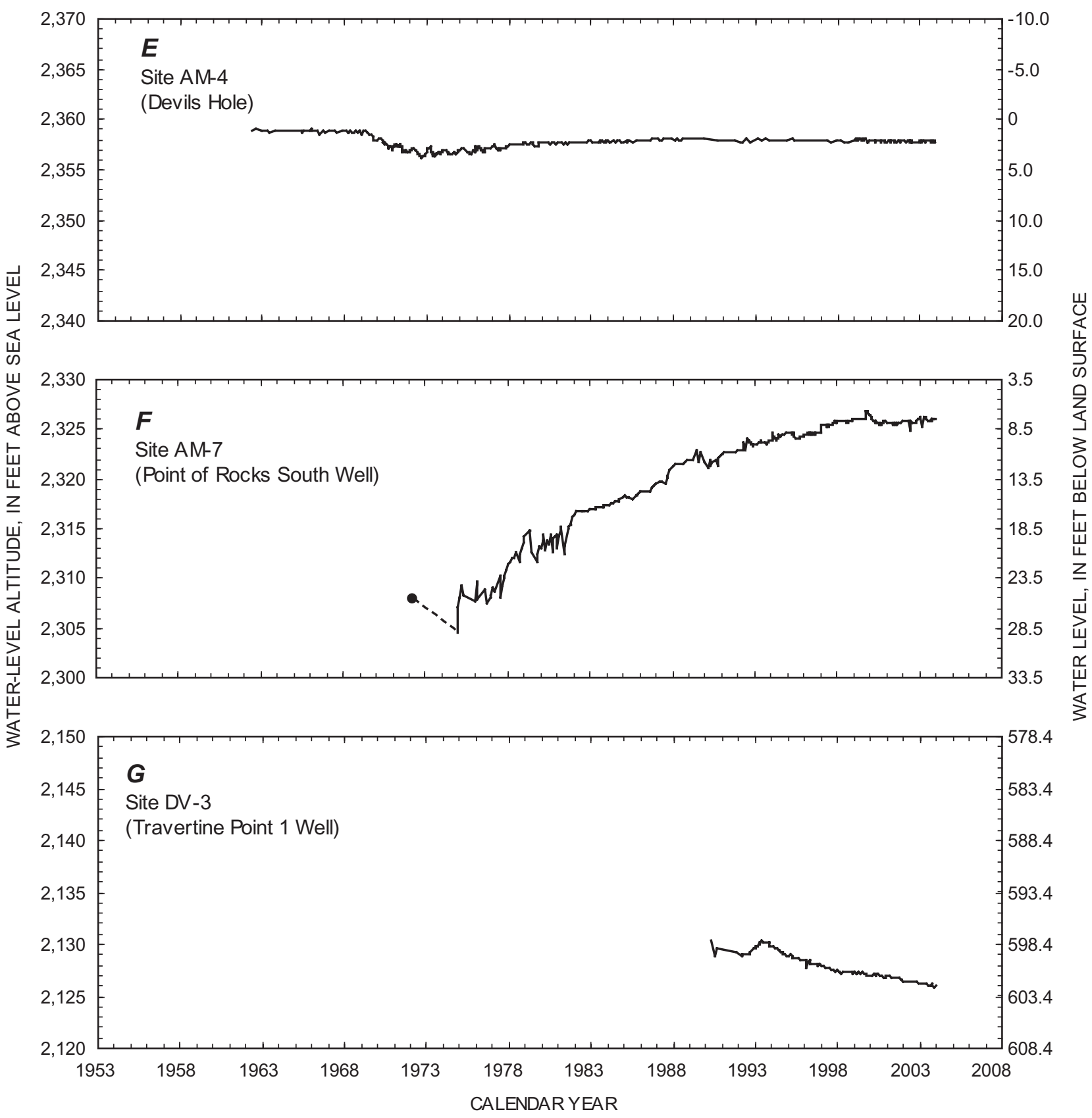

Figure 2. Continued. 

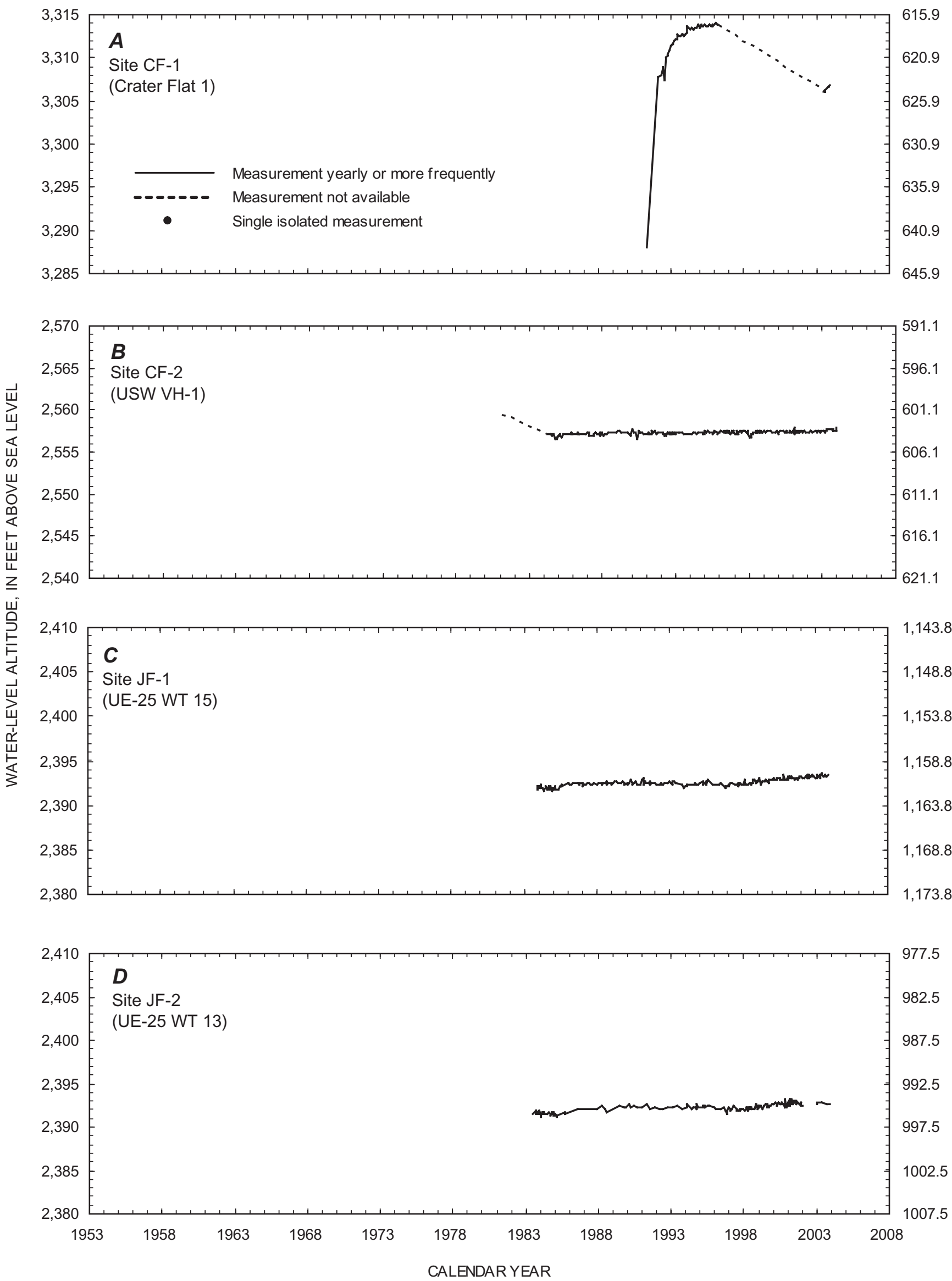

Figure 3. Periodic water levels for selected sites through 2003 at which primary contributing units are volcanic rock. 
22 Selected Ground-Water Data for Yucca Mountain Region, Southern Nevada and Eastern California, January-December 2003
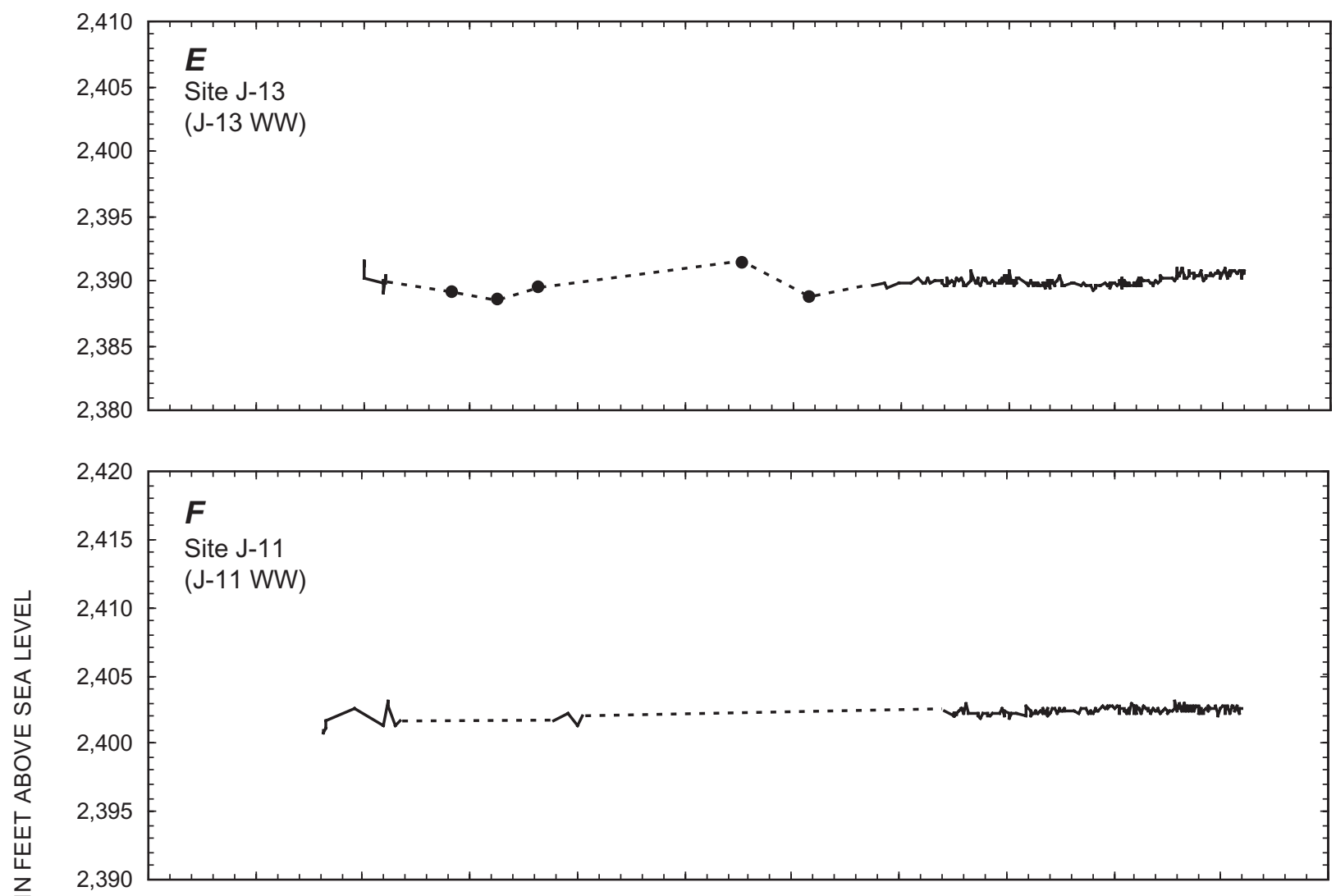

$1,022.8$

$1,027.8$

$1,032.8$

$1,037.8$

$1,042.8$

$1,047.8$

$1,052.8$

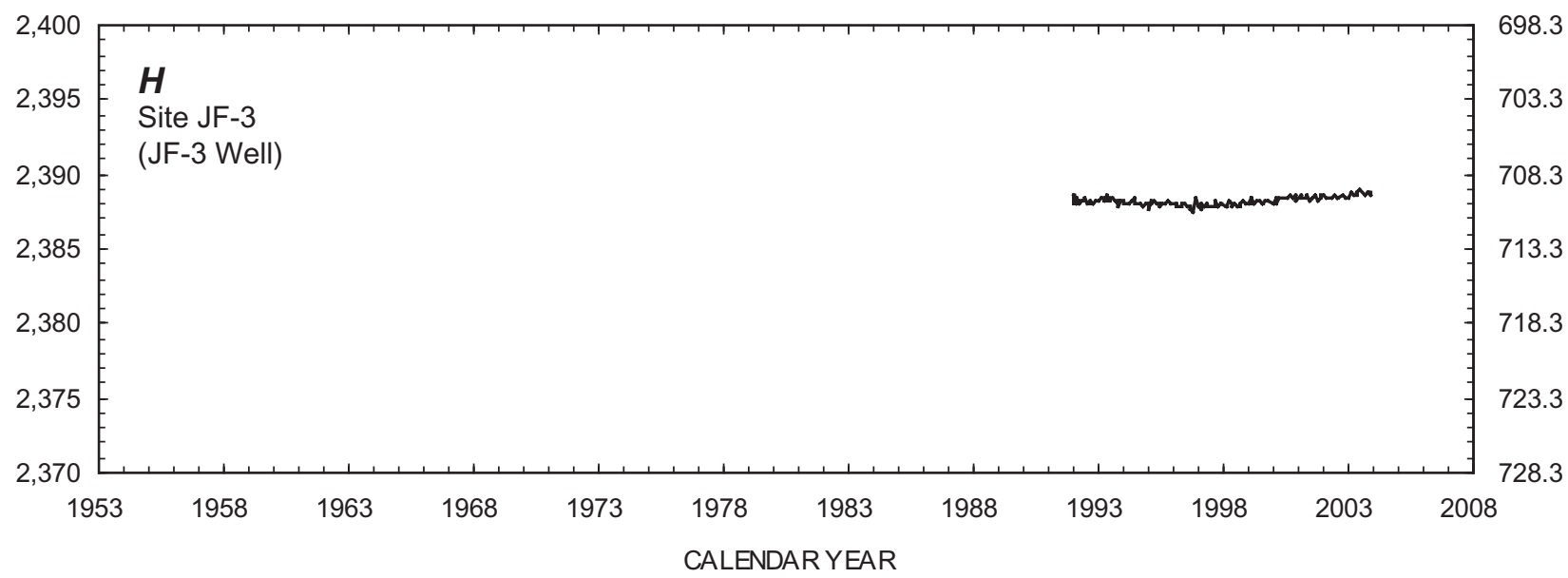

Figure 3. Continued. 

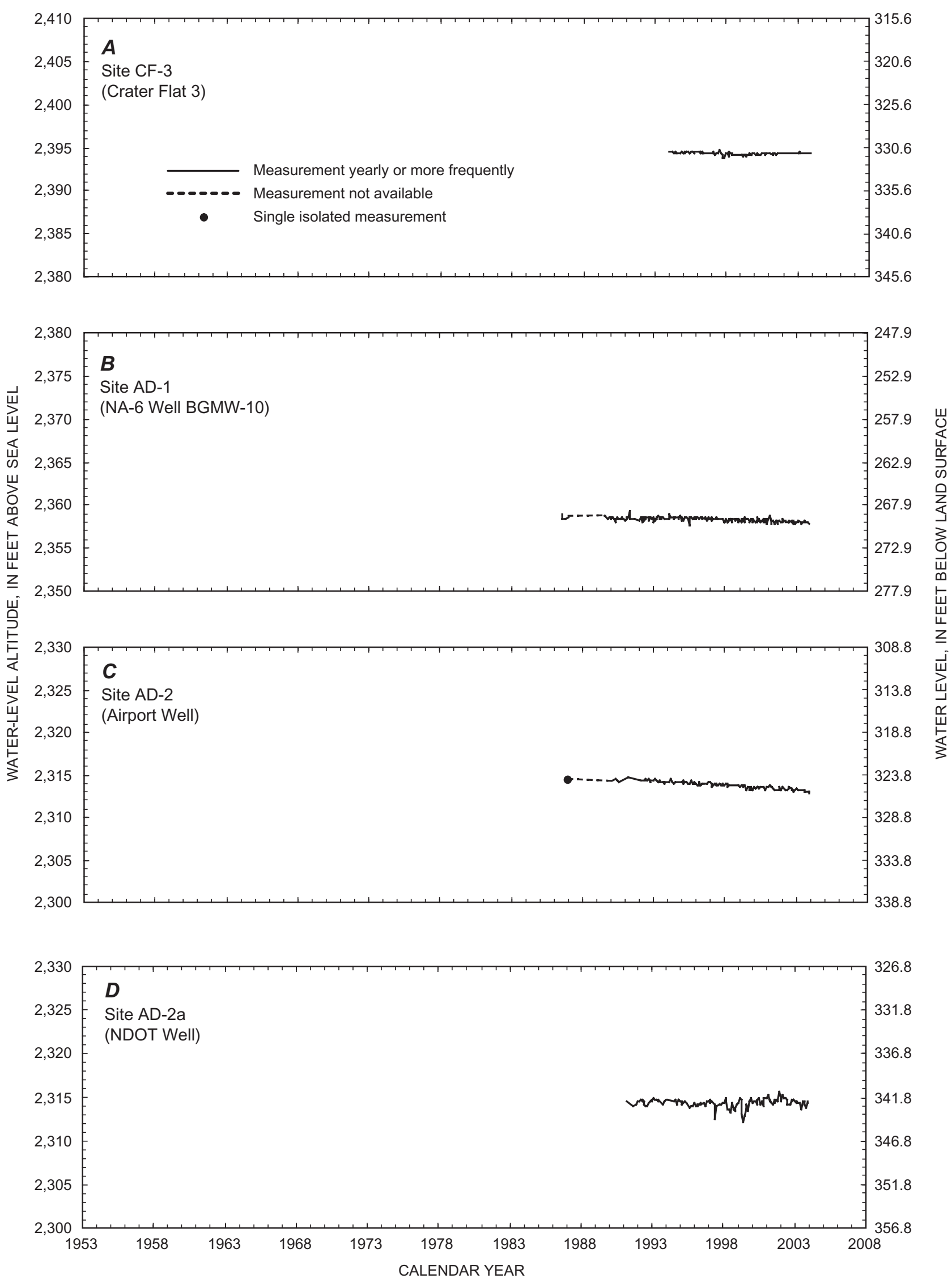

Figure 4. Periodic water levels for selected sites through 2003 at which primary contributing units are valley fill. 
24 Selected Ground-Water Data for Yucca Mountain Region, Southern Nevada and Eastern California, January-December 2003
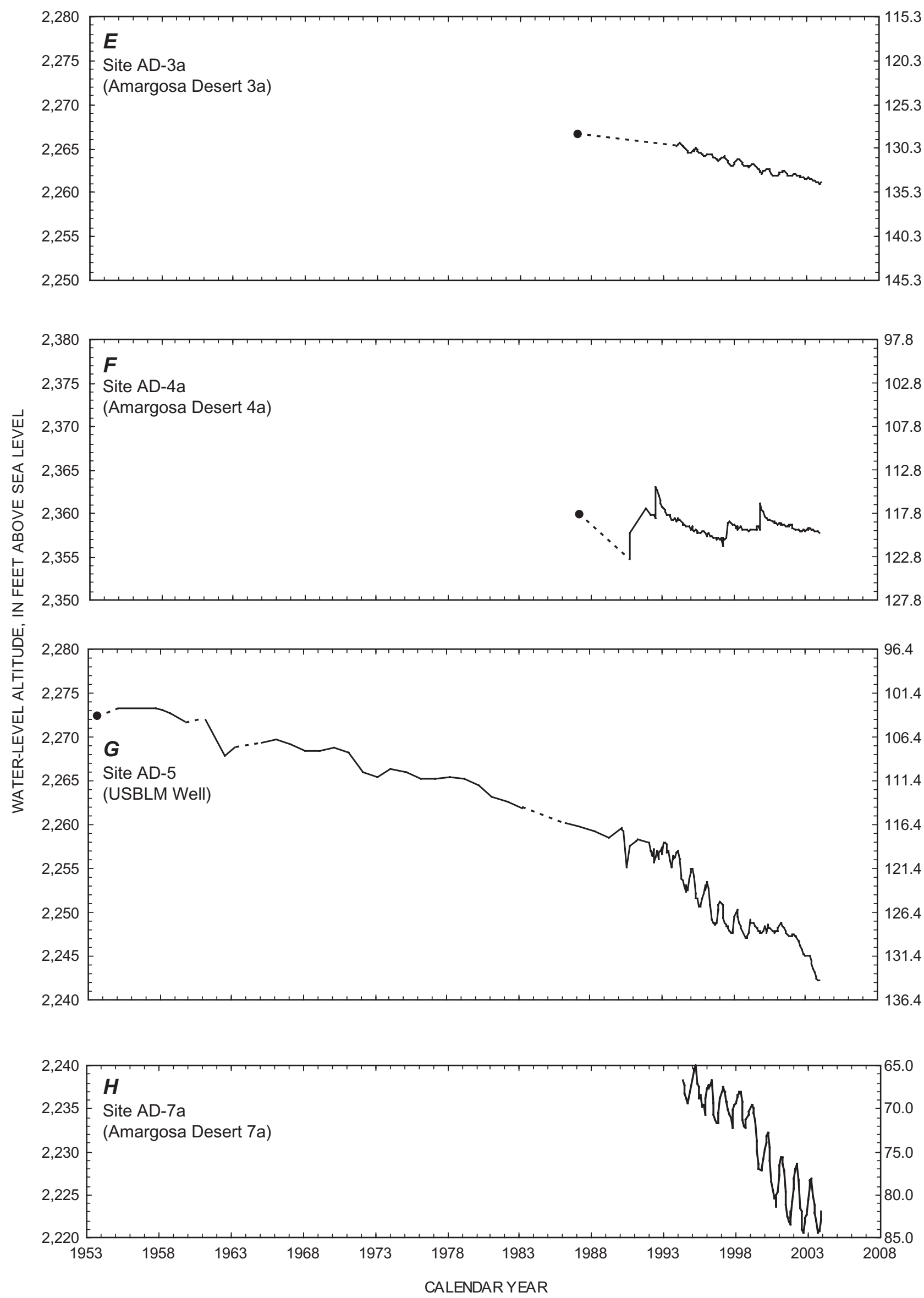

Figure 4. Continued. 
Basic Data
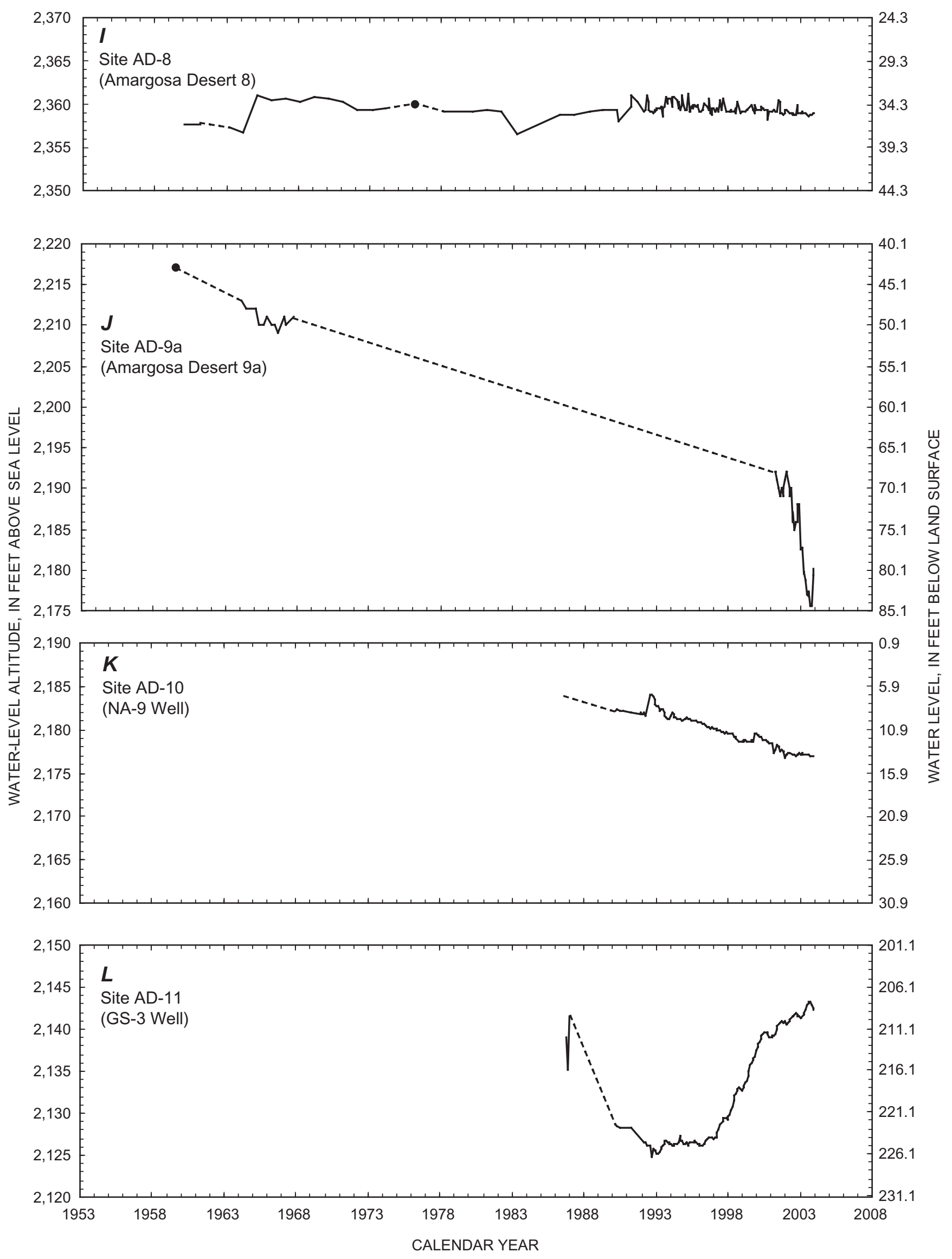

Figure 4. Continued. 
26 Selected Ground-Water Data for Yucca Mountain Region, Southern Nevada and Eastern California, January-December 2003
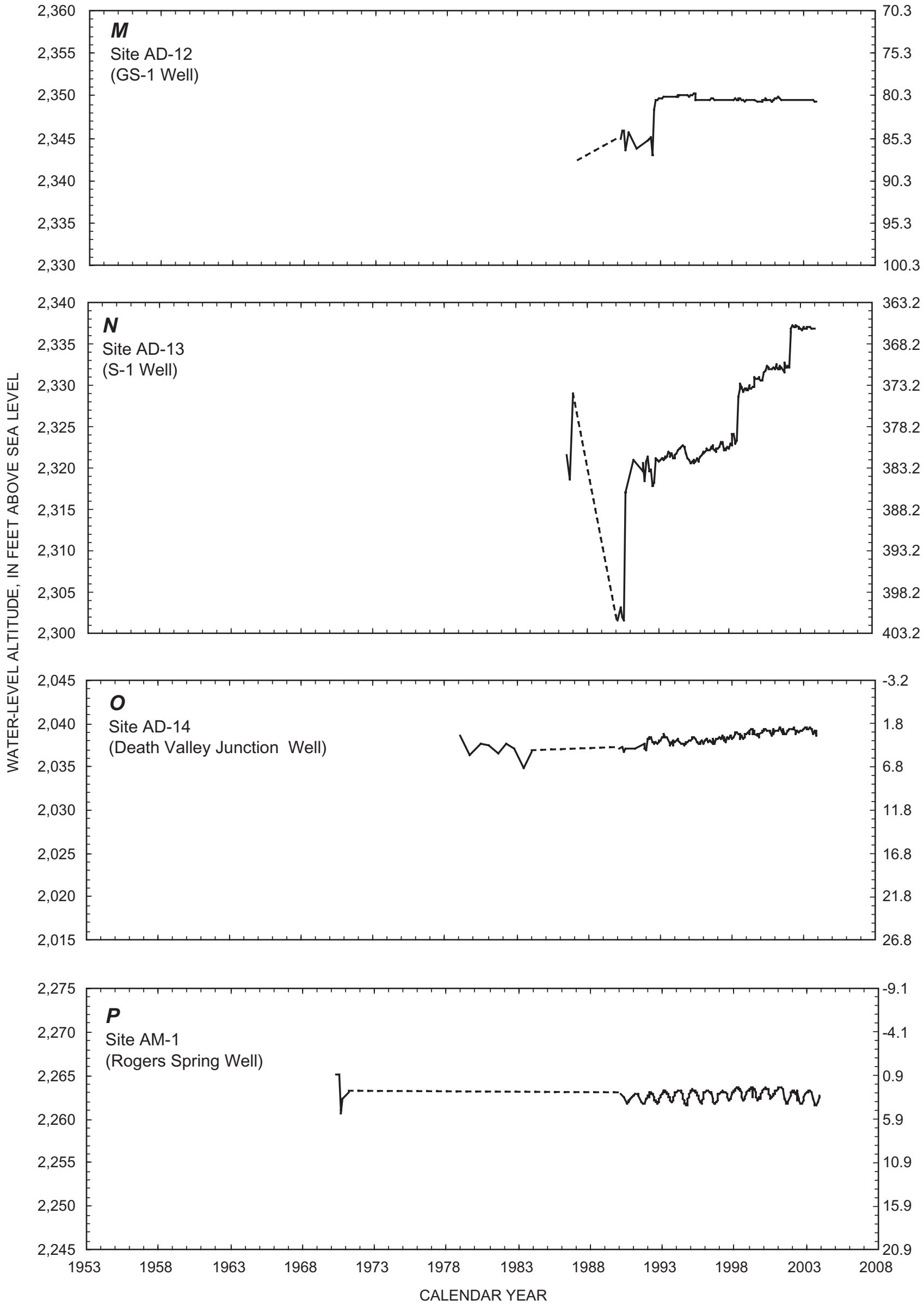

Figure 4. Continued. 


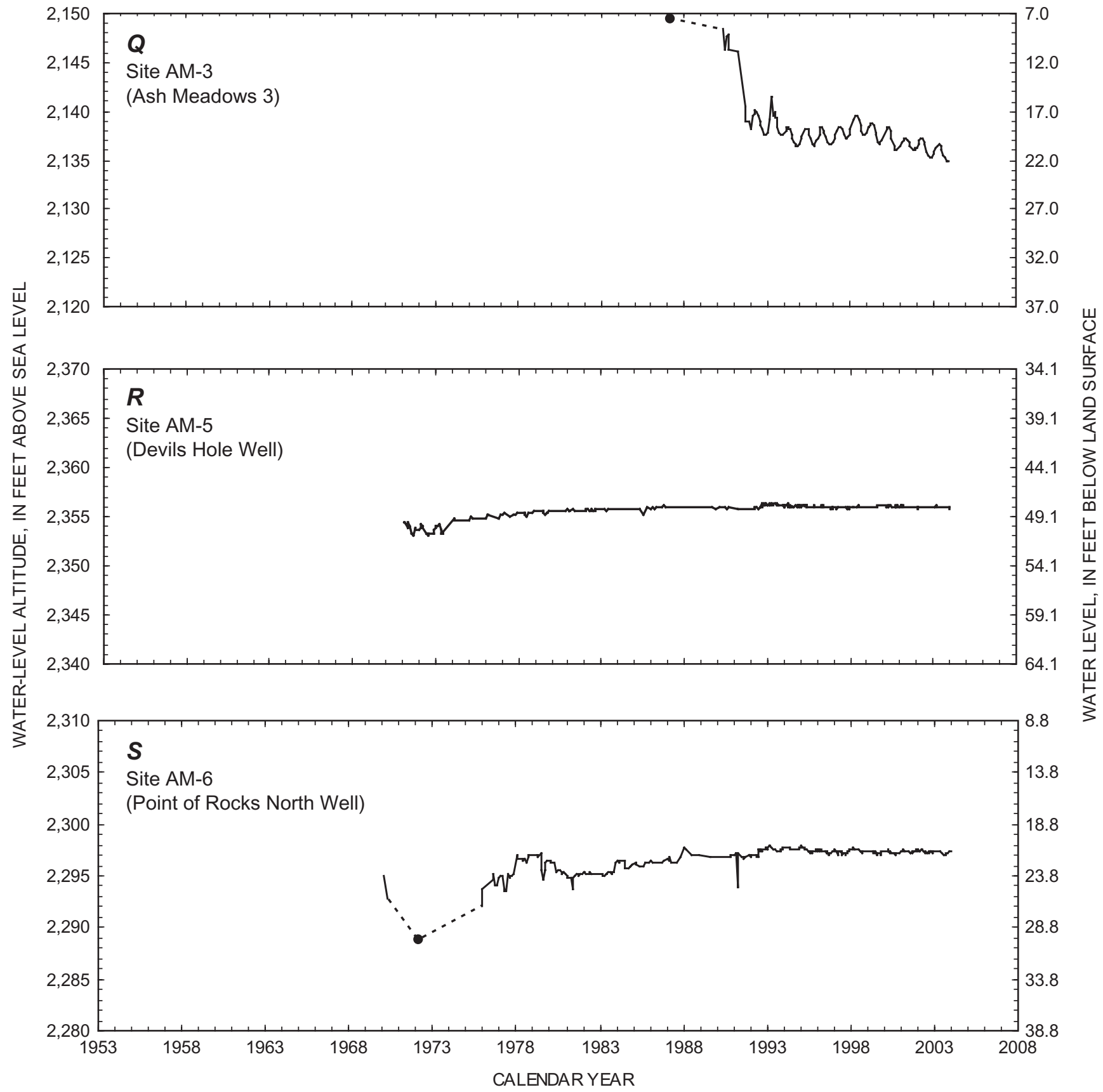

Figure 4. Continued. 


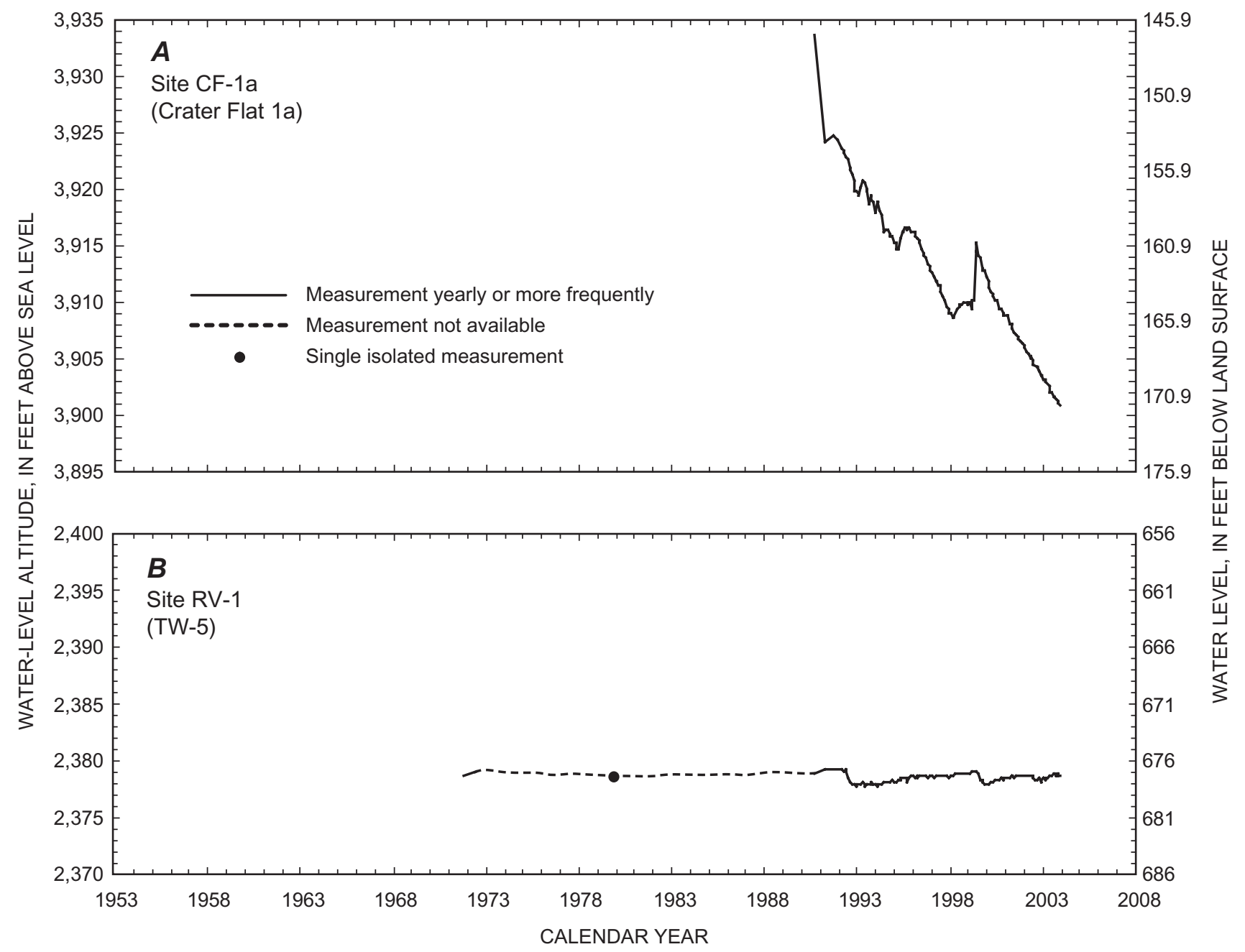

Figure 5. Periodic water levels for selected sites through 2003 at which primary contributing units are undifferentiated sedimentary rock. 


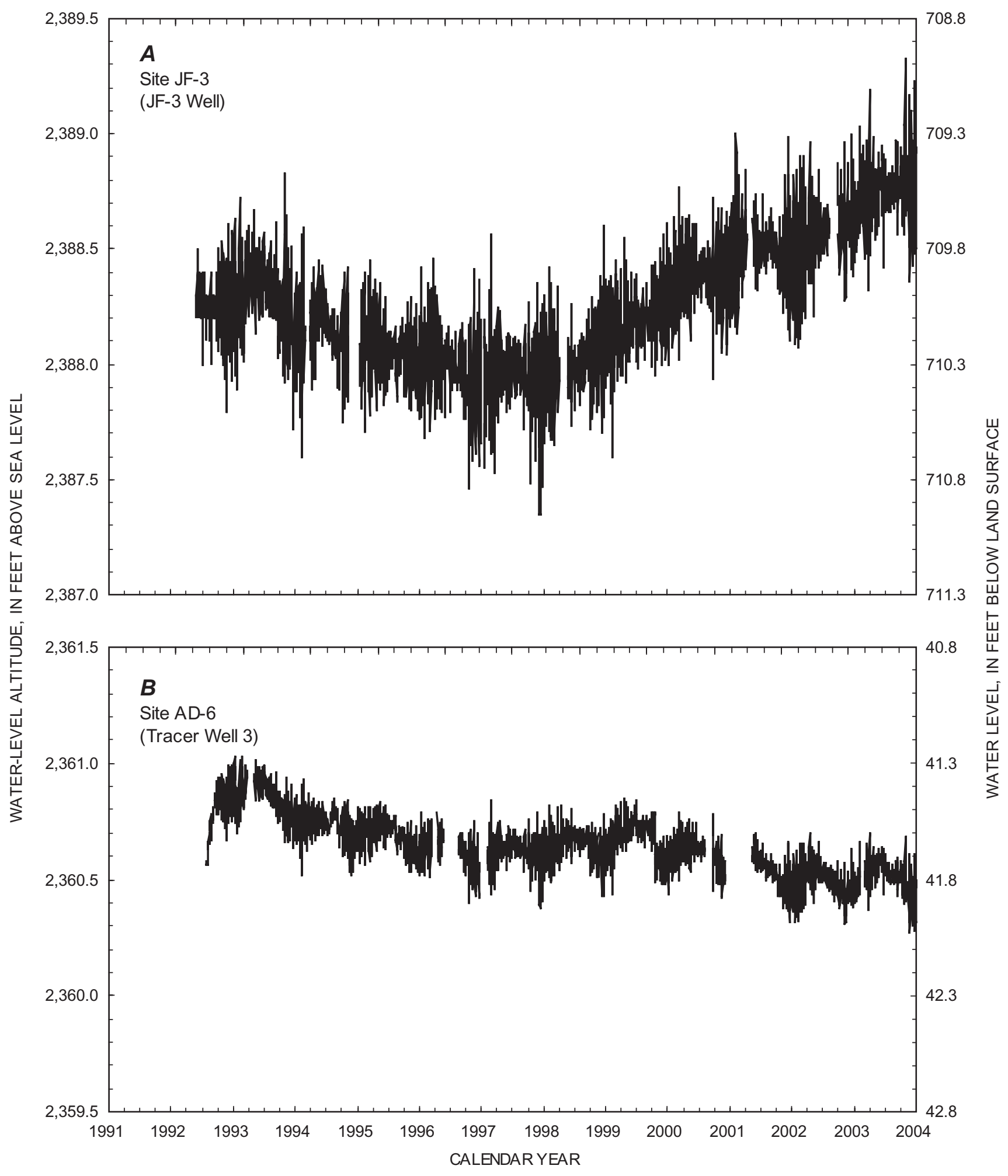

Figure 6. Daily average water levels in well JF-3, May 1992-December 2003 and in well AD-6, July 1992-December 2003. 


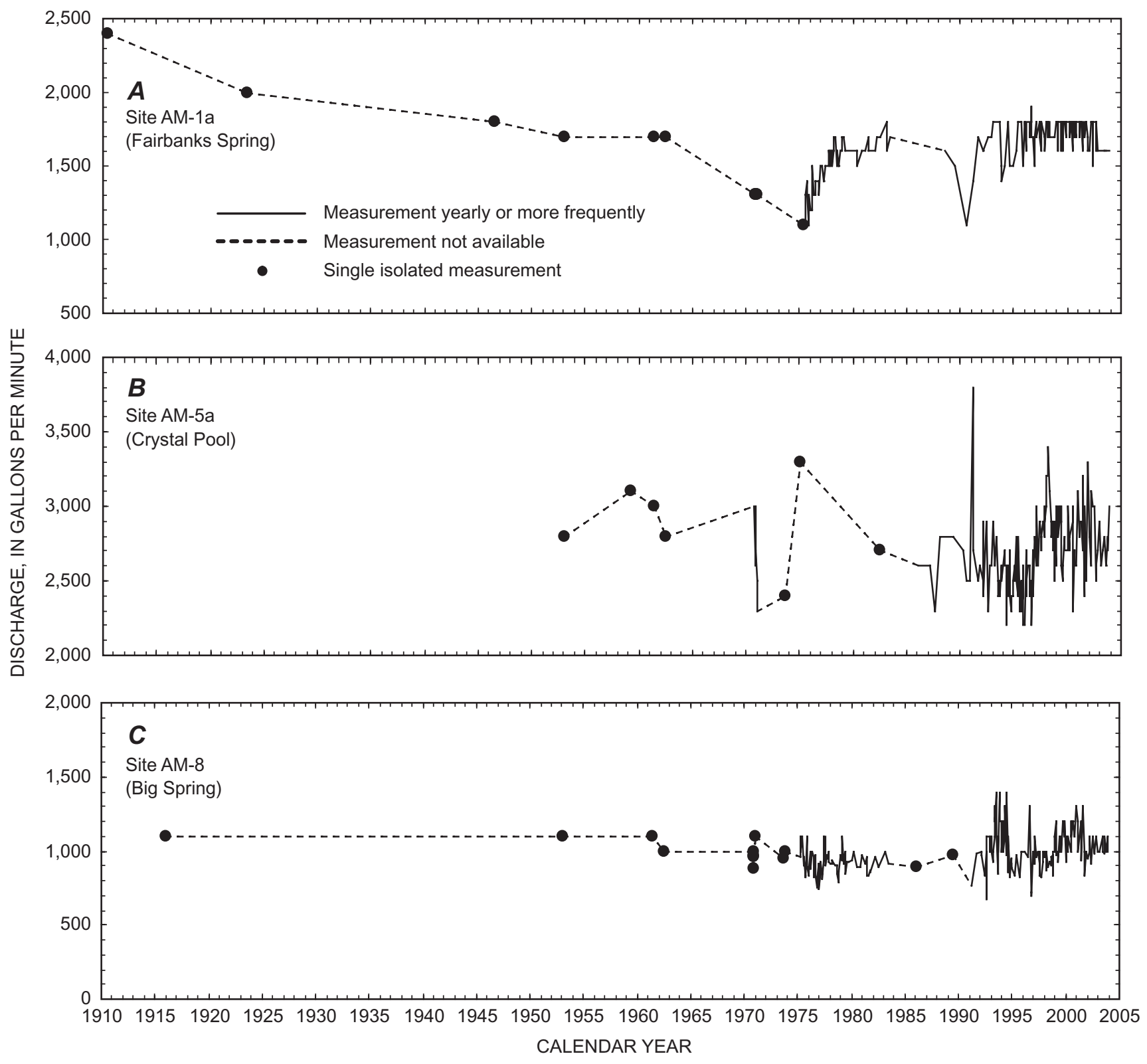

Figure 7. Discharge at sites AM-1a (Fairbanks Spring), AM-5a (Crystal Pool), and AM-8 (Big Spring), 1910-2003. 


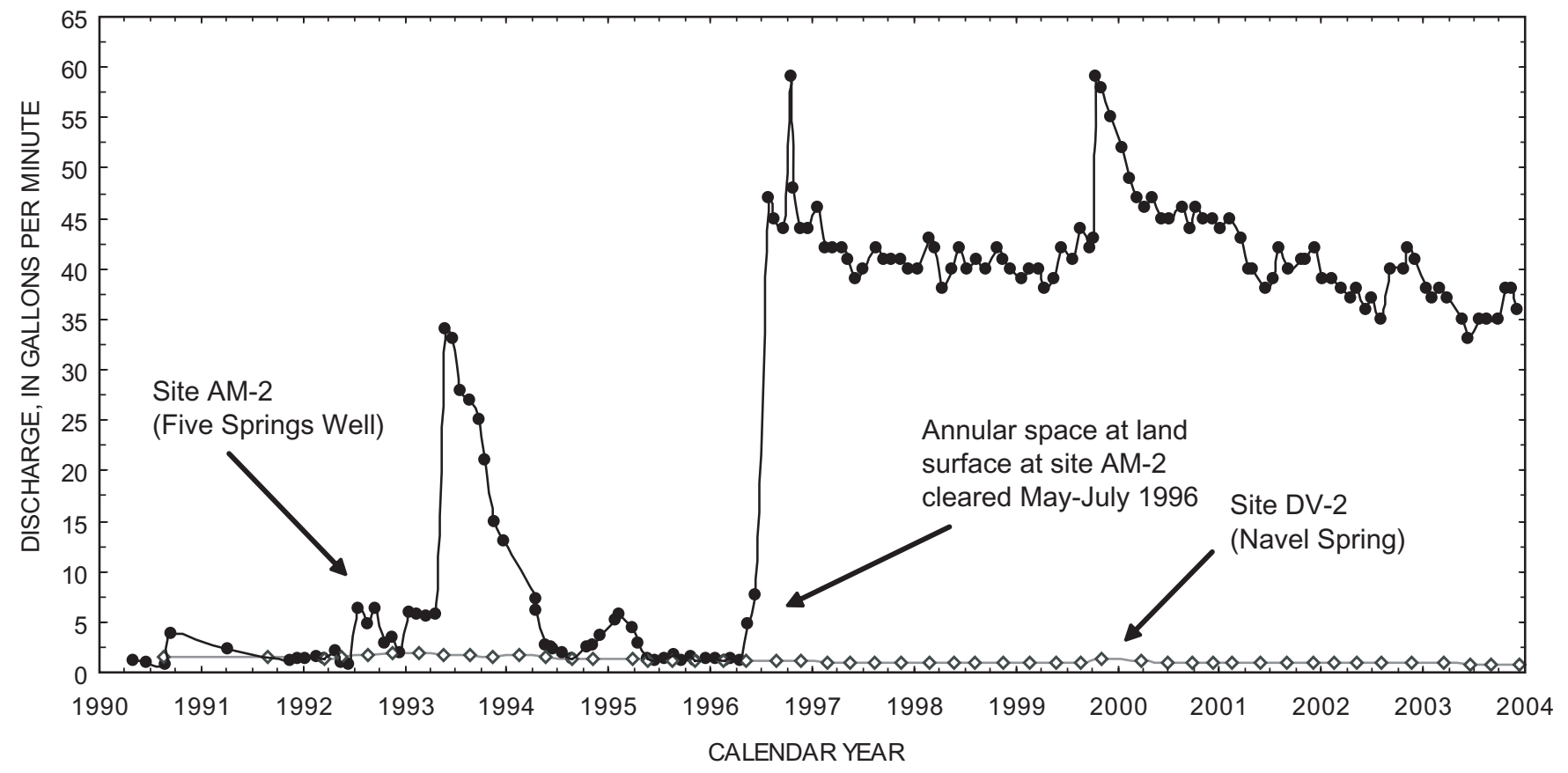

Figure 8. Discharge at sites AM-2 (Five Springs Well) and DV-2 (Navel Spring), 1990-2003.

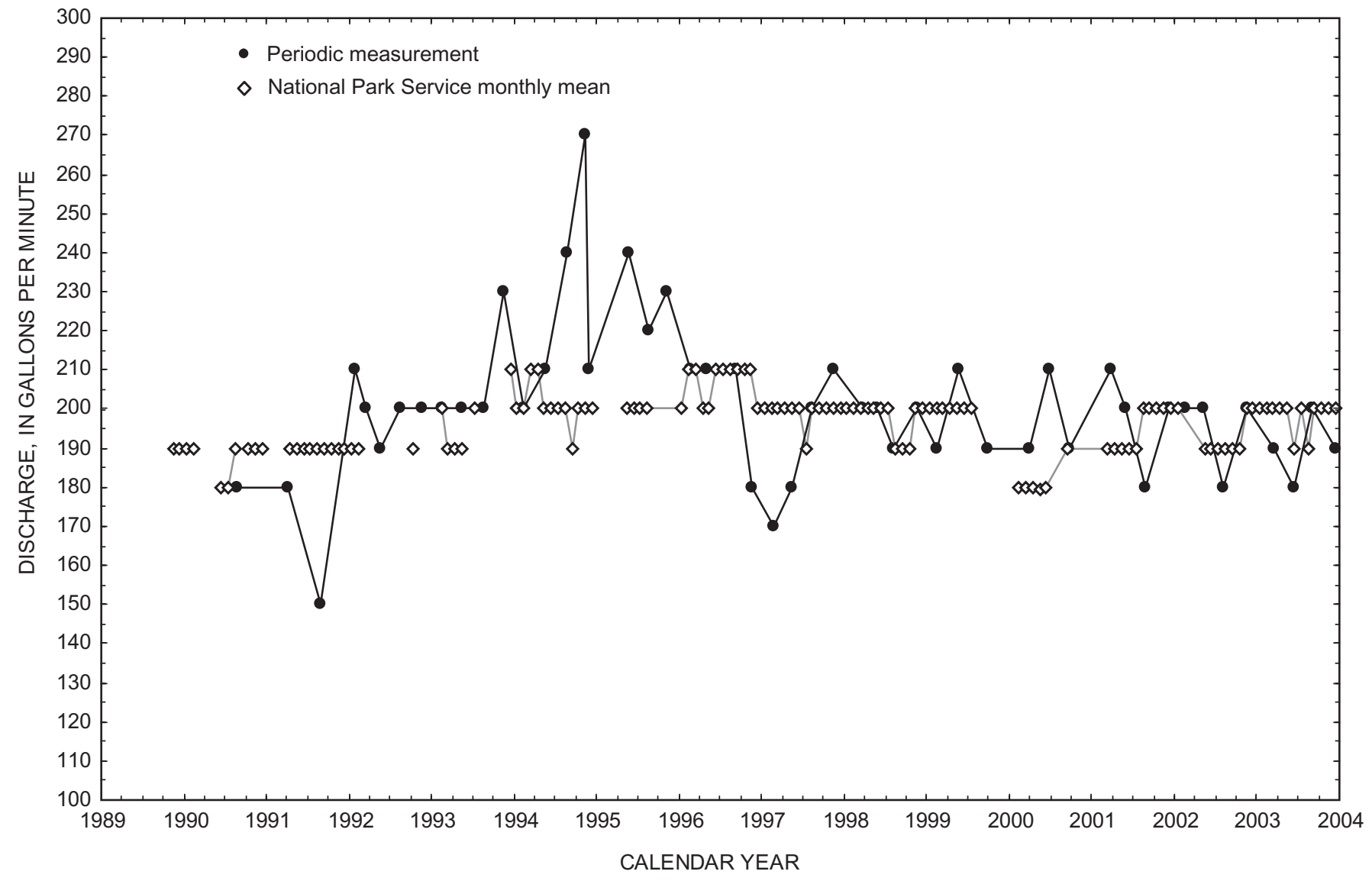

Figure 9. Discharge at site DV-1 (Texas Spring), 1989-2003. 


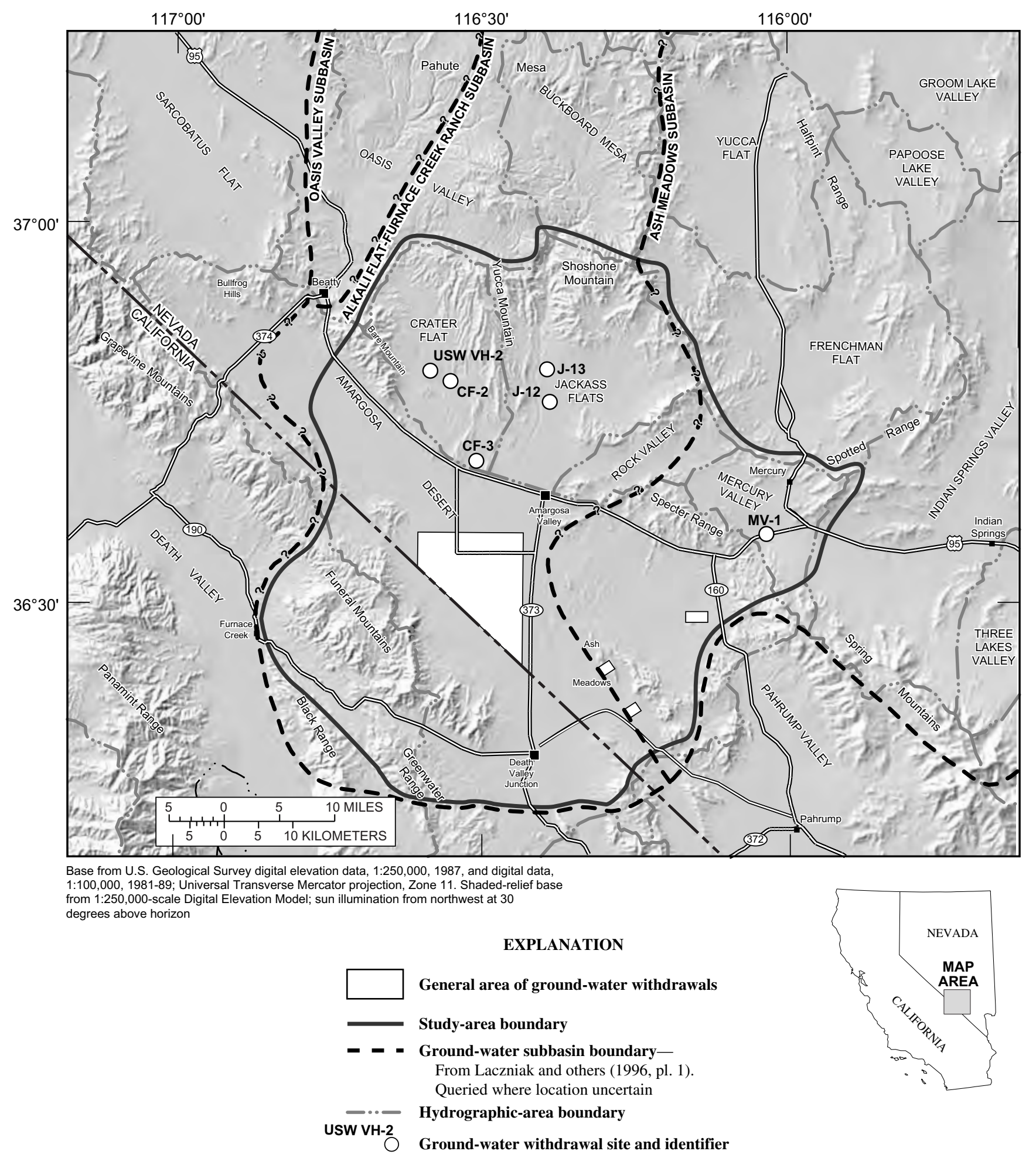

Figure 10. Location of ground-water withdrawal sites and general areas of ground-water withdrawals in the Yucca Mountain region of southern Nevada and eastern California, January-December 2003. 


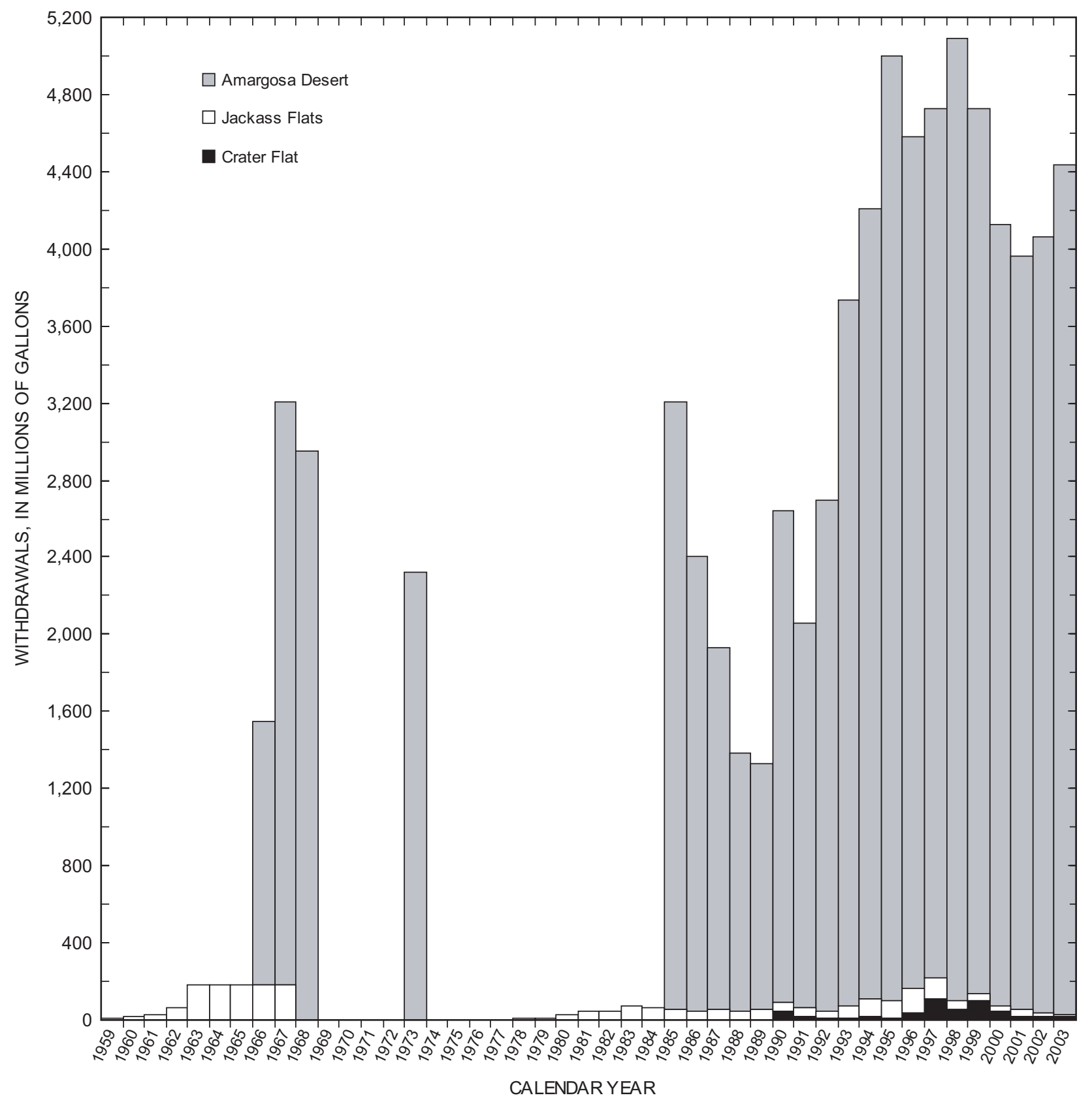

Figure 11. Available estimates of annual ground-water withdrawals for selected areas within Alkali Flat-Furnace Creek Ranch groundwater subbasin, 1959-2003. 


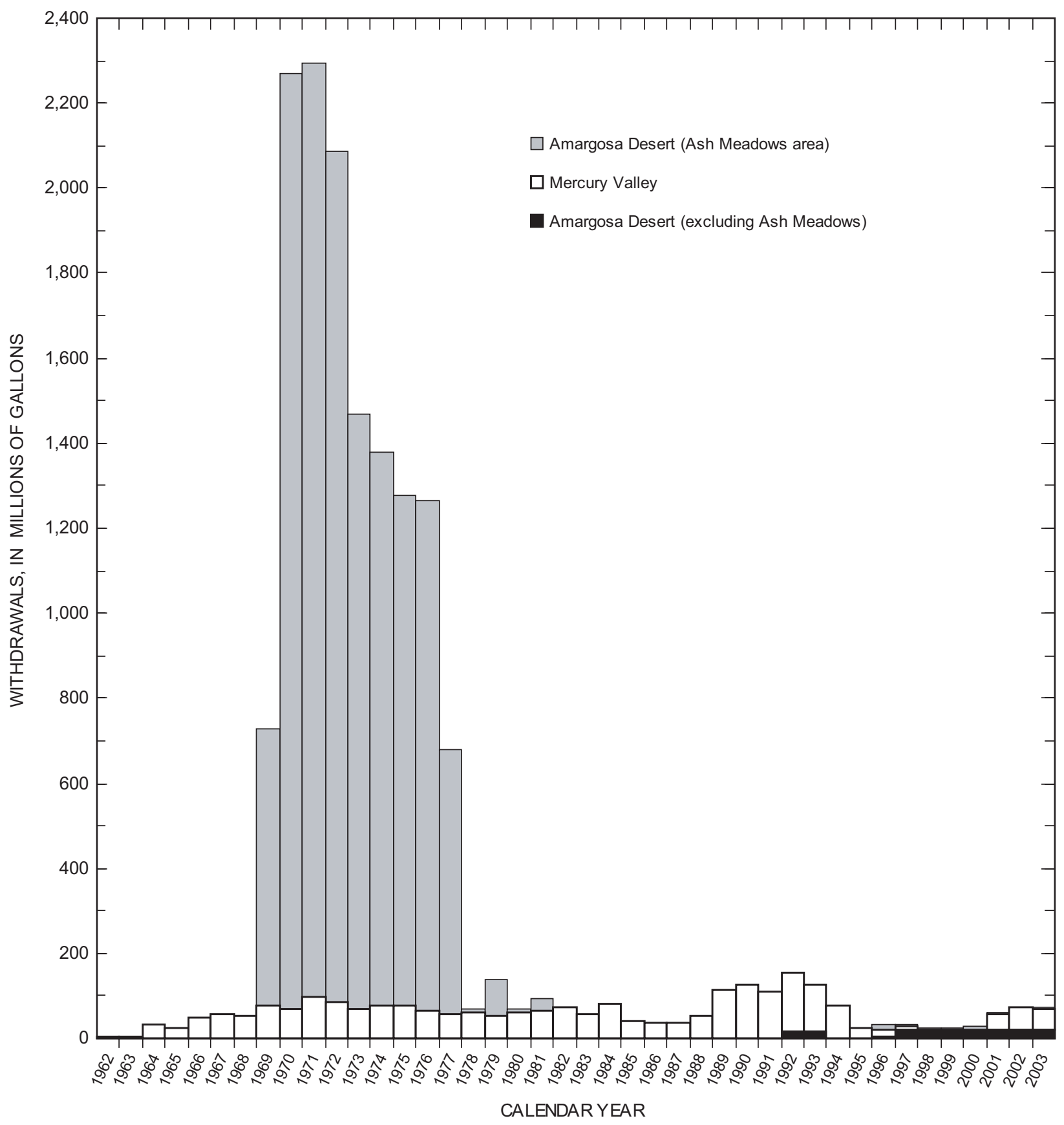

Figure 12. Available estimates of annual ground-water withdrawals for selected areas within Ash Meadows ground-water subbasin, 1962-2003. 

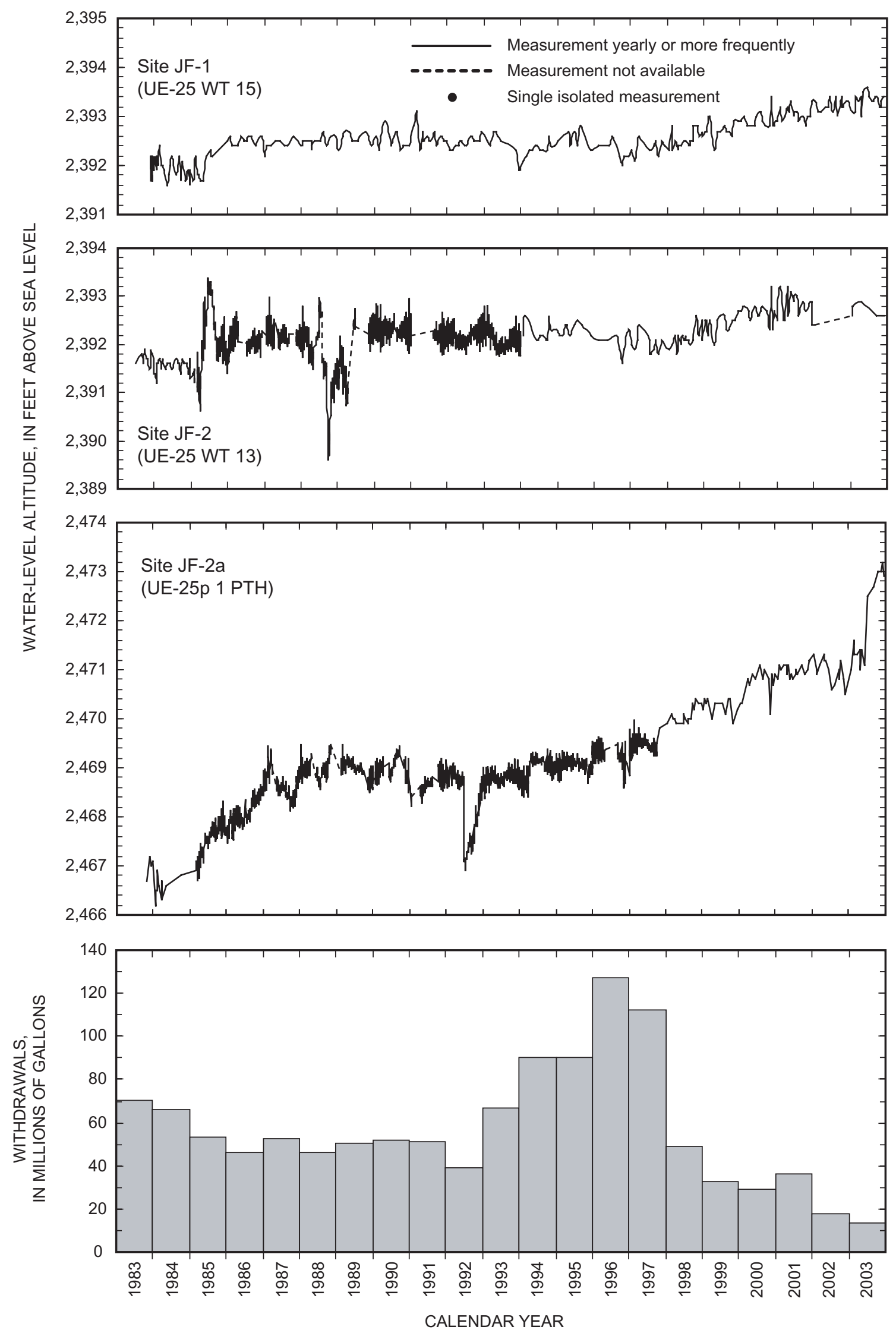

Figure 13. Water-level altitudes in wells JF-1, JF-2, JF-2a, J-13, J-11, J-12, and JF-3 and estimated annual ground-water withdrawals from Jackass Flats, 1983-2003. 

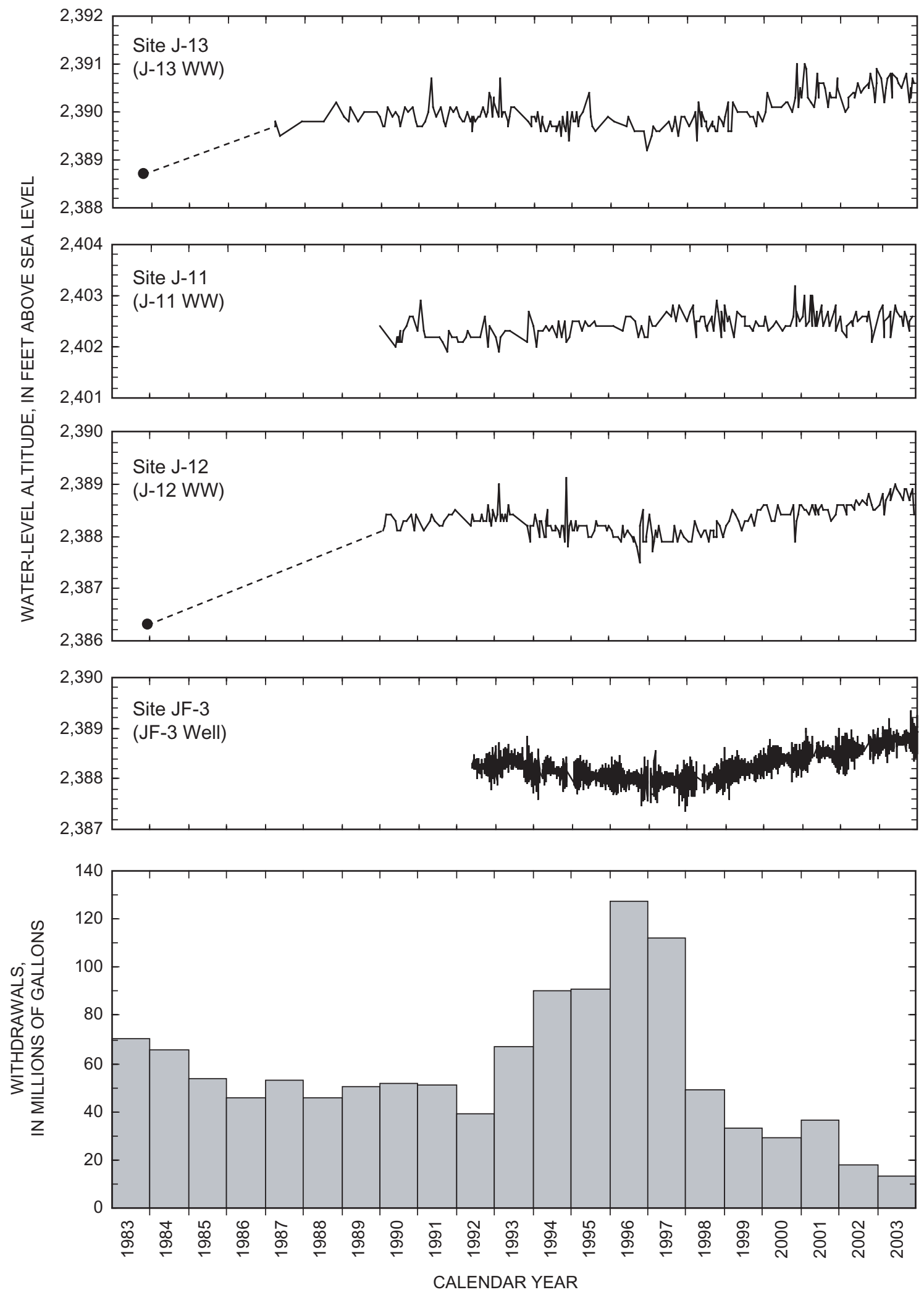

Figure 13. Continued. 

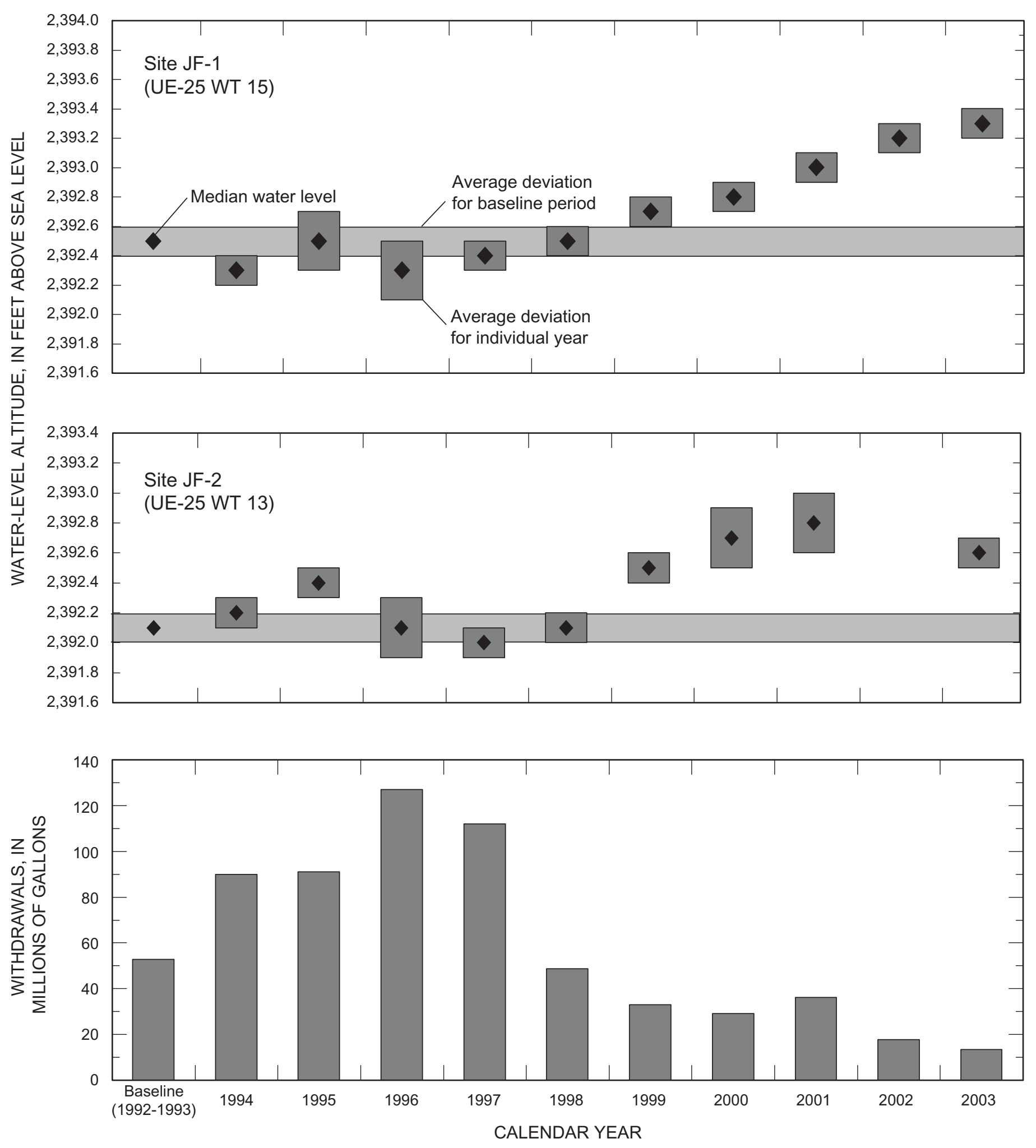

Figure 14. Median water-level altitutdes and average deviation of water levels for wells JF-1, JF-2, JF-2a, J-13, J-11, J-12, and JF-3, and estimated annual ground-water withdrawals from Jackass Flats, for 1992-93 baseline period and for 1994-2003. 

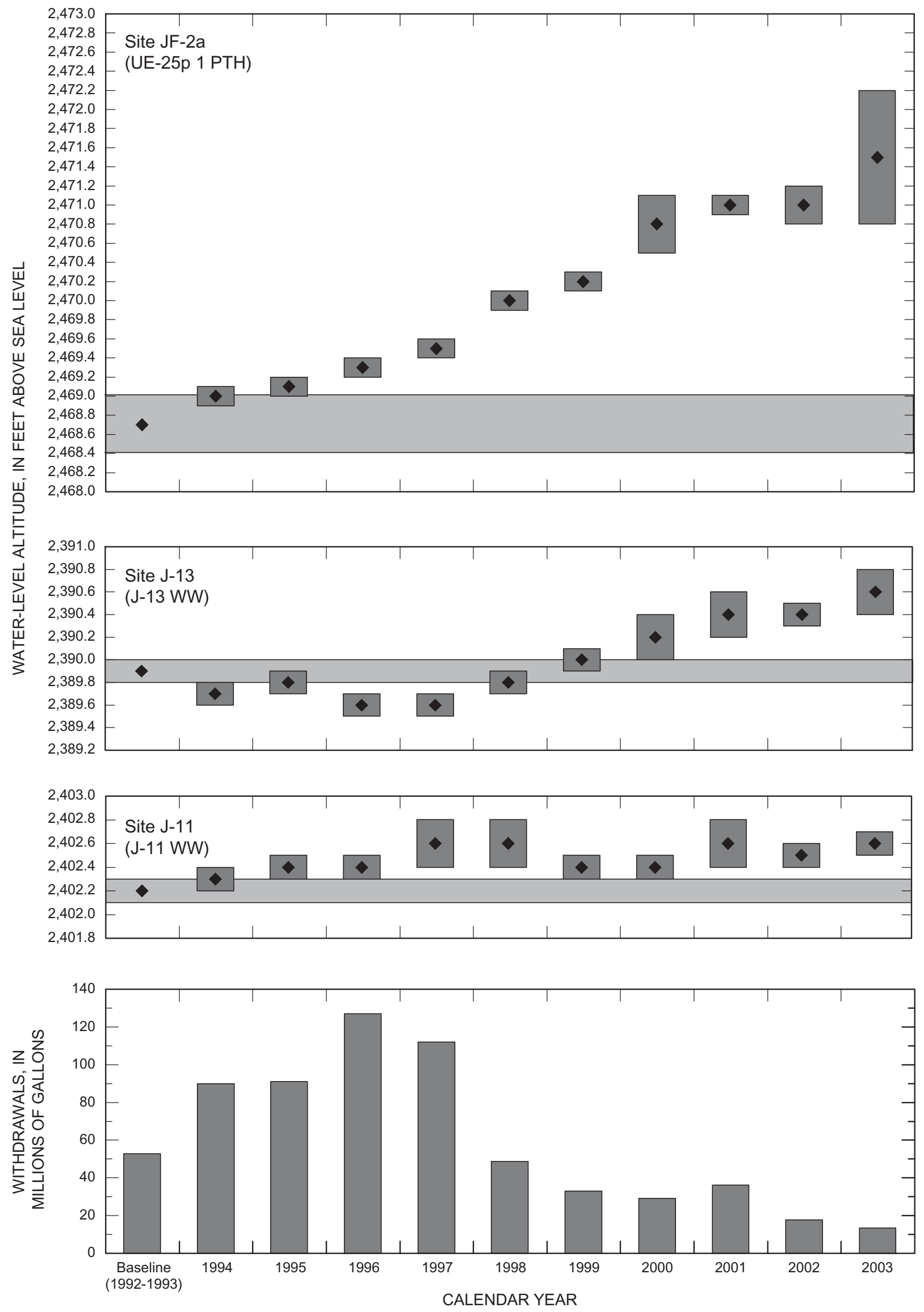

Figure 14. Continued 

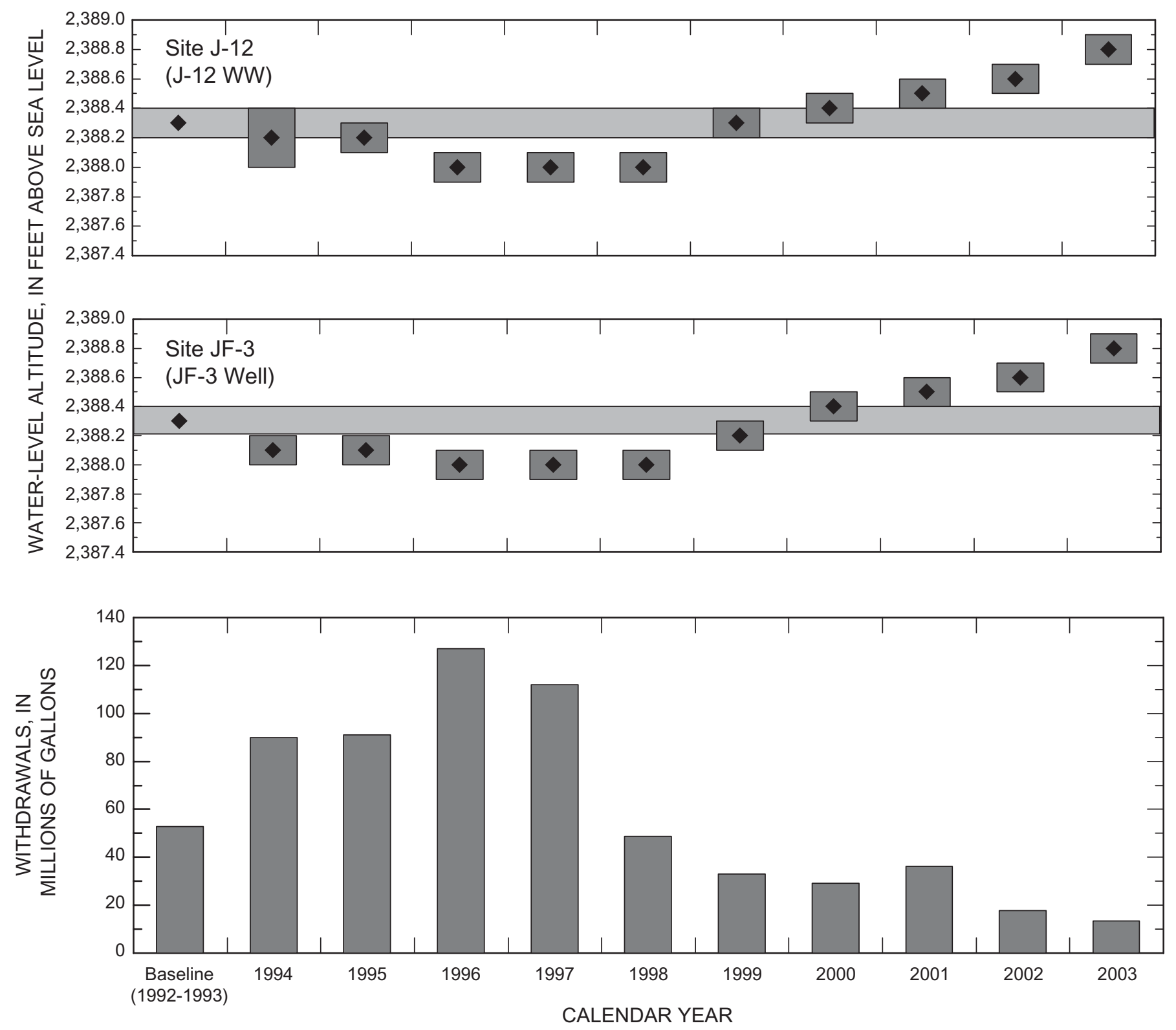

Figure 14. Continued. 
Table 5. Periodic water-level data at monitoring sites in Yucca Mountain region, 2003

Site Number: Alphanumeric identifier used to identify sites on maps and tables. First part represents hydrographic area in which site is located. Hydrographic areas: CF, Crater Flat; JF or J, Jackass Flats; RV, Rock Valley; MV, Mercury Valley; AD or AM, Amargosa Desert; DV, Death Valley. Second part is sequential numbering representing relative location of site within hydrographic area or Ash Meadows springdischarge area; numbering order generally is north to south, then west to east. Sites J-13, J-11, and J-12 previously were numbered by Raytheon Services Nevada and herein were not renumbered.

U.S. Geological Survey site identification: Unique identification number for site as stored in files and data bases of U.S. Geological Survey (USGS).

Land-surface altitude: Referenced to the National Geodetic Vertical Datum of 1929. Representative altitude of land surface in vicinity of site. Exception is altitude for site AM-4, which is altitude of bolt that serves as measurement point. Altitudes are reported to nearest 0.1 foot and were derived from land surveys.

Height of measurement point: Height of measurement point (MP) used. MP is stable, recoverable point from which periodic measurements of depth to water are made. MP at site AM-4 is bolt fastened to south wall of fissure, and is not referenced to land surface. Negative number indicates MP is below land surface.

Depth to water: Depths listed generally represent water level below land surface. An exception is site AM-4, where data represent water levels below measurement point. Apparent differences in depth to water at sites that list data from several sources may result from differing estimates of distance from land surface to measurement point used.

Altitude of water surface: Referenced to the National Geodetic Vertical Datum of 1929. Land-surface altitude minus depth to water, reported to nearest 0.1 foot.

Method: Method used to measure depth to water. A, average monthly water level (reported for the 15th of the month); F, pressure transducer; N, ruled tape; R, reported (measurement method unknown); S, steel tape; T, electric tape; V, calibrated electric tape.

Site status: Known conditions at site that may have affected measured depth to water. F, flowing; P, pumping; R, well recently pumped; Z, measurement made in pump-discharge column.

-Data source: EMP, Environmental-Monitoring Program (USGS); HRC, Harry Reid Center for Environmental Studies (University of Nevada, Las Vegas); NDWR, Nevada Division of Water Resources; NPS, National Park Service; NTS, Nevada Test Site USGS/Department of Energy Cooperative Program; USFWS, U.S. Fish and Wildlife Service.

\begin{tabular}{|c|c|c|c|c|c|c|c|c|c|c|c|}
\hline \multirow[b]{2}{*}{$\begin{array}{c}\text { Site } \\
\text { number } \\
\text { (fig. 1) }\end{array}$} & \multirow[b]{2}{*}{$\begin{array}{l}\text { U.S. Geological } \\
\text { Survey site } \\
\text { identification }\end{array}$} & \multirow[b]{2}{*}{ Site name } & \multirow{2}{*}{$\begin{array}{c}\text { Land- } \\
\text { surface } \\
\text { altitude } \\
\text { (feet above } \\
\text { sea level) }\end{array}$} & \multirow{2}{*}{$\begin{array}{l}\text { Height of } \\
\text { measure- } \\
\text { ment } \\
\text { point (feet } \\
\text { above land } \\
\text { surface) }\end{array}$} & \multicolumn{7}{|c|}{ Water-level measurement } \\
\hline & & & & & Date & Time & $\begin{array}{l}\text { Depth to } \\
\text { water (feet } \\
\text { below land } \\
\text { surface) }\end{array}$ & $\begin{array}{c}\text { Altitude of } \\
\text { water surface } \\
\text { (feet above } \\
\text { sea level) }\end{array}$ & Method & $\begin{array}{c}\text { Site } \\
\text { status }\end{array}$ & $\begin{array}{l}\text { Data } \\
\text { source }\end{array}$ \\
\hline \multirow[t]{7}{*}{ CF-1 } & 365520116370301 & Crater Flat 1 & $3,930.9$ & 1.77 & $06-26-2003$ & 1755 & 624.89 & $3,306.0$ & $\mathrm{~V}$ & - & EMP \\
\hline & & & & & $07-28-2003$ & 1321 & 624.79 & $3,306.1$ & $\mathrm{~V}$ & - & EMP \\
\hline & & & & & $08-12-2003$ & 1556 & 624.56 & $3,306.3$ & $\mathrm{~V}$ & - & EMP \\
\hline & & & & & 09-25-2003 & 0945 & 624.41 & $3,306.5$ & $\mathrm{~V}$ & - & EMP \\
\hline & & & & & $10-23-2003$ & 1658 & 624.25 & $3,306.6$ & $\mathrm{~V}$ & - & EMP \\
\hline & & & & & $11-07-2003$ & 1057 & 624.17 & $3,306.7$ & $\mathrm{~V}$ & - & EMP \\
\hline & & & & & $12-08-2003$ & 1544 & 623.98 & $3,306.9$ & $\mathrm{~V}$ & - & EMP \\
\hline \multirow[t]{12}{*}{ CF-1a } & 365445116383901 & Crater Flat 1a & $4,080.9$ & 1.68 & $01-28-2003$ & 0808 & 177.72 & $3,903.2$ & $\mathrm{~S}$ & - & EMP \\
\hline & & & & & 02-07-2003 & 1123 & 177.79 & $3,903.1$ & $\mathrm{~S}$ & - & EMP \\
\hline & & & & & 03-07-2003 & 0938 & 178.00 & $3,902.9$ & $S$ & - & EMP \\
\hline & & & & & 04-23-2003 & 1623 & 178.31 & $3,902.6$ & $\mathrm{~S}$ & - & EMP \\
\hline & & & & & $05-27-2003$ & 1013 & 178.79 & $3,902.1$ & $\mathrm{~S}$ & - & EMP \\
\hline & & & & & 06-17-2003 & 0706 & 178.77 & $3,902.1$ & $\mathrm{~S}$ & - & EMP \\
\hline & & & & & 07-28-2003 & 1254 & 179.17 & $3,901.7$ & $\mathrm{~S}$ & - & EMP \\
\hline & & & & & $08-12-2003$ & 1518 & 179.20 & $3,901.7$ & $\mathrm{~S}$ & - & EMP \\
\hline & & & & & 09-25-2003 & 0914 & 179.55 & $3,901.4$ & $\mathrm{~S}$ & - & EMP \\
\hline & & & & & $10-23-2003$ & 1614 & 179.65 & $3,901.2$ & $\mathrm{~S}$ & - & EMP \\
\hline & & & & & $11-07-2003$ & 1144 & 179.87 & $3,901.0$ & $\mathrm{~S}$ & - & EMP \\
\hline & & & & & $12-08-2003$ & 1619 & 180.01 & $3,900.9$ & $\mathrm{~S}$ & - & EMP \\
\hline
\end{tabular}


Table 5. Periodic water-level data at monitoring sites in Yucca Mountain region, 2003-Continued

\begin{tabular}{|c|c|c|c|c|c|c|c|c|c|c|c|}
\hline \multirow[b]{2}{*}{$\begin{array}{c}\text { Site } \\
\text { number } \\
\text { (fig. 1) }\end{array}$} & \multirow[b]{2}{*}{$\begin{array}{l}\text { U.S. Geological } \\
\text { Survey site } \\
\text { identification }\end{array}$} & \multirow[b]{2}{*}{ Site name } & \multirow{2}{*}{$\begin{array}{c}\text { Land- } \\
\text { surface } \\
\text { altitude } \\
\text { (feet above } \\
\text { sea level) }\end{array}$} & \multirow{2}{*}{$\begin{array}{l}\text { Height of } \\
\text { measure- } \\
\text { ment } \\
\text { point (feet } \\
\text { above land } \\
\text { surface) }\end{array}$} & \multicolumn{7}{|c|}{ Water-level measurement } \\
\hline & & & & & Date & Time & $\begin{array}{l}\text { Depth to } \\
\text { water (feet } \\
\text { below land } \\
\text { surface) }\end{array}$ & $\begin{array}{c}\text { Altitude of } \\
\text { water surface } \\
\text { (feet above } \\
\text { sea level) }\end{array}$ & Method & $\begin{array}{c}\text { Site } \\
\text { status }\end{array}$ & $\begin{array}{l}\text { Data } \\
\text { source }\end{array}$ \\
\hline \multirow[t]{16}{*}{$\mathrm{CF}-2$} & 364732116330701 & USW VH-1 & $3,161.1$ & 1.17 & $01-23-2003$ & 0757 & 603.64 & $2,557.5$ & $\mathrm{~S}$ & - & EMP \\
\hline & & & & & $02-21-2003$ & -- & 603.69 & $2,557.4$ & $\mathrm{~V}$ & - & HRC \\
\hline & & & & & $02-21-2003$ & 1024 & 603.69 & $2,557.4$ & $\mathrm{~V}$ & - & EMP \\
\hline & & & & & $03-27-2003$ & 0821 & 603.59 & $2,557.5$ & $\mathrm{~V}$ & - & EMP \\
\hline & & & & & $04-25-2003$ & -- & 603.57 & $2,557.5$ & $\mathrm{~V}$ & - & $\mathrm{HRC}$ \\
\hline & & & & & 04-29-2003 & 0816 & 603.62 & $2,557.5$ & $\mathrm{~V}$ & - & EMP \\
\hline & & & & & 05-06-2003 & 1741 & 603.33 & $2,557.8$ & $\mathrm{~V}$ & - & EMP \\
\hline & & & & & $06-23-2003$ & 1554 & 603.30 & $2,557.8$ & $\mathrm{~V}$ & - & EMP \\
\hline & & & & & $07-28-2003$ & 1426 & 603.43 & $2,557.7$ & $\mathrm{~V}$ & - & EMP \\
\hline & & & & & $08-12-2003$ & 1717 & 603.39 & $2,557.7$ & $\mathrm{~V}$ & - & EMP \\
\hline & & & & & 09-19-2003 & 1114 & 603.52 & $2,557.6$ & $\mathrm{~S}$ & - & $\mathrm{HRC}$ \\
\hline & & & & & 09-25-2003 & 0804 & 603.35 & $2,557.8$ & $\mathrm{~V}$ & - & EMP \\
\hline & & & & & $10-08-2003$ & 0745 & 603.54 & $2,557.6$ & $\mathrm{~S}$ & - & EMP \\
\hline & & & & & $11-07-2003$ & 0938 & 603.53 & $2,557.6$ & $\mathrm{~V}$ & - & EMP \\
\hline & & & & & $12-08-2003$ & 1433 & 603.62 & $2,557.5$ & $\mathrm{~V}$ & - & EMP \\
\hline & & & & & $12-10-2003$ & 1355 & 603.20 & $2,557.9$ & $\mathrm{~V}$ & - & $\mathrm{HRC}$ \\
\hline \multirow[t]{14}{*}{$\mathrm{CF}-3$} & 364105116302601 & Crater Flat 3 & $2,725.6$ & -3.20 & $01-28-2003$ & 0638 & 331.21 & $2,394.4$ & $\mathrm{~S}$ & - & EMP \\
\hline & & & & & $02-24-2003$ & 1531 & 331.11 & $2,394.5$ & $\mathrm{~S}$ & - & EMP \\
\hline & & & & & $03-12-2003$ & 0636 & 331.23 & $2,394.4$ & $\mathrm{~S}$ & - & EMP \\
\hline & & & & & $04-28-2003$ & 1526 & 331.68 & $2,393.9$ & $\mathrm{~V}$ & $\mathrm{P}$ & EMP \\
\hline & & & & & $04-28-2003$ & 1556 & 331.15 & $2,394.4$ & $\mathrm{~V}$ & - & EMP \\
\hline & & & & & $05-22-2003$ & 0620 & 331.67 & $2,393.9$ & V & $\mathrm{P}$ & EMP \\
\hline & & & & & $05-22-2003$ & 0646 & 331.18 & $2,394.4$ & V & - & EMP \\
\hline & & & & & 06-17-2003 & 0601 & 331.16 & $2,394.4$ & $S$ & - & EMP \\
\hline & & & & & $07-24-2003$ & 0555 & 331.18 & $2,394.4$ & $\mathrm{~S}$ & - & EMP \\
\hline & & & & & 08-20-2003 & 0630 & 331.20 & $2,394.4$ & $\mathrm{~S}$ & - & EMP \\
\hline & & & & & $09-25-2003$ & 0625 & 331.19 & $2,394.4$ & $\mathrm{~S}$ & - & EMP \\
\hline & & & & & $10-24-2003$ & 0642 & 331.72 & $2,393.9$ & V & $\mathrm{P}$ & EMP \\
\hline & & & & & $11-18-2003$ & 0616 & 331.24 & $2,394.4$ & $\mathrm{~V}$ & - & EMP \\
\hline & & & & & $12-19-2003$ & 0840 & 331.16 & $2,394.4$ & $\mathrm{~V}$ & - & EMP \\
\hline
\end{tabular}




\begin{tabular}{|c|c|c|c|c|c|c|c|c|c|c|c|}
\hline \multirow[b]{2}{*}{$\begin{array}{c}\text { Site } \\
\text { number } \\
\text { (fig. 1) }\end{array}$} & \multirow[b]{2}{*}{$\begin{array}{l}\text { U.S. Geological } \\
\text { Survey site } \\
\text { identification }\end{array}$} & \multirow[b]{2}{*}{ Site name } & \multirow{2}{*}{$\begin{array}{c}\text { Land- } \\
\text { surface } \\
\text { altitude } \\
\text { (feet above } \\
\text { sea level) }\end{array}$} & \multirow{2}{*}{$\begin{array}{l}\text { Height of } \\
\text { measure- } \\
\text { ment } \\
\text { point (feet } \\
\text { above land } \\
\text { surface) }\end{array}$} & \multicolumn{7}{|c|}{ Water-level measurement } \\
\hline & & & & & Date & Time & $\begin{array}{l}\text { Depth to } \\
\text { water (feet } \\
\text { below land } \\
\text { surface) }\end{array}$ & $\begin{array}{c}\text { Altitude of } \\
\text { water surface } \\
\text { (feet above } \\
\text { sea level) }\end{array}$ & Method & $\begin{array}{l}\text { Site } \\
\text { status }\end{array}$ & $\begin{array}{l}\text { Data } \\
\text { source }\end{array}$ \\
\hline \multirow[t]{16}{*}{ JF-1 } & 365116116233801 & UE-25 WT 15 & $3,553.8$ & 0.18 & $01-22-2003$ & 1005 & $1,160.69$ & $2,393.1$ & $\mathrm{~S}$ & - & EMP \\
\hline & & & & & 02-19-2003 & -- & $1,160.68$ & $2,393.1$ & $\mathrm{~V}$ & - & HRC \\
\hline & & & & & $02-20-2003$ & 1248 & $1,160.38$ & $2,393.4$ & $\mathrm{~V}$ & - & EMP \\
\hline & & & & & 03-21-2003 & 0845 & $1,160.54$ & $2,393.3$ & $\mathrm{~V}$ & - & EMP \\
\hline & & & & & 04-28-2003 & 0835 & $1,160.38$ & $2,393.4$ & $\mathrm{~V}$ & - & EMP \\
\hline & & & & & 04-30-2003 & -- & $1,160.83$ & $2,393.0$ & $\mathrm{~V}$ & - & HRC \\
\hline & & & & & 05-06-2003 & 1452 & $1,160.31$ & $2,393.5$ & $\mathrm{~V}$ & - & EMP \\
\hline & & & & & $06-23-2003$ & 1027 & $1,160.23$ & $2,393.6$ & $\mathrm{~V}$ & - & EMP \\
\hline & & & & & 07-07-2003 & 1245 & $1,160.39$ & $2,393.4$ & $\mathrm{~V}$ & - & EMP \\
\hline & & & & & 08-13-2003 & 0840 & $1,160.47$ & $2,393.3$ & $\mathrm{~V}$ & - & EMP \\
\hline & & & & & $08-28-2003$ & 1237 & $1,160.48$ & $2,393.3$ & $\mathrm{~V}$ & - & HRC \\
\hline & & & & & $09-24-2003$ & 1439 & $1,160.38$ & $2,393.4$ & $\mathrm{~V}$ & - & EMP \\
\hline & & & & & $10-27-2003$ & 1030 & $1,160.61$ & $2,393.2$ & $\mathrm{~V}$ & - & EMP \\
\hline & & & & & $11-04-2003$ & 1201 & $1,160.59$ & $2,393.2$ & $\mathrm{~V}$ & - & HRC \\
\hline & & & & & $11-06-2003$ & 1509 & $1,160.51$ & $2,393.3$ & $\mathrm{~V}$ & - & EMP \\
\hline & & & & & $12-04-2003$ & 1440 & $1,160.42$ & $2,393.4$ & $\mathrm{~V}$ & - & EMP \\
\hline \multirow[t]{10}{*}{ JF-2 } & 364945116235001 & UE-25 WT 13 & $3,387.5$ & 1.00 & $01-23-2003$ & -- & 994.92 & $2,392.6$ & $\mathrm{~V}$ & - & HRC \\
\hline & & & & & $01-31-2003$ & 1606 & 994.75 & $2,392.8$ & $\mathrm{~F}$ & - & HRC \\
\hline & & & & & 02-01-2003 & 1606 & 994.75 & $2,392.8$ & $\mathrm{~F}$ & - & HRC \\
\hline & & & & & 04-30-2003 & 1306 & 994.62 & $2,392.9$ & $\mathrm{~F}$ & - & HRC \\
\hline & & & & & 09-17-2003 & 1120 & 994.91 & $2,392.6$ & $\mathrm{~F}$ & - & $\mathrm{HRC}$ \\
\hline & & & & & 09-23-2003 & 1120 & 994.89 & $2,392.6$ & $\mathrm{~F}$ & - & HRC \\
\hline & & & & & $10-15-2003$ & 1120 & 994.95 & $2,392.6$ & $\mathrm{~F}$ & - & HRC \\
\hline & & & & & $11-15-2003$ & 1020 & 994.94 & $2,392.6$ & $\mathrm{~F}$ & - & HRC \\
\hline & & & & & $12-10-2003$ & 1020 & 994.87 & $2,392.6$ & $\mathrm{~F}$ & - & HRC \\
\hline & & & & & $12-15-2003$ & 1020 & 994.91 & $2,392.6$ & $\mathrm{~F}$ & - & HRC \\
\hline
\end{tabular}


Table 5. Periodic water-level data at monitoring sites in Yucca Mountain region, 2003-Continued

\begin{tabular}{|c|c|c|c|c|c|c|c|c|c|c|c|}
\hline \multirow[b]{2}{*}{$\begin{array}{c}\text { Site } \\
\text { number } \\
\text { (fig. 1) }\end{array}$} & \multirow[b]{2}{*}{$\begin{array}{l}\text { U.S. Geological } \\
\text { Survey site } \\
\text { identification }\end{array}$} & \multirow[b]{2}{*}{ Site name } & \multirow{2}{*}{$\begin{array}{c}\text { Land- } \\
\text { surface } \\
\text { altitude } \\
\text { (feet above } \\
\text { sea level) }\end{array}$} & \multirow{2}{*}{$\begin{array}{l}\text { Height of } \\
\text { measure- } \\
\text { ment } \\
\text { point (feet } \\
\text { above land } \\
\text { surface) }\end{array}$} & \multicolumn{7}{|c|}{ Water-level measurement } \\
\hline & & & & & Date & Time & $\begin{array}{l}\text { Depth to } \\
\text { water (feet } \\
\text { below land } \\
\text { surface) }\end{array}$ & $\begin{array}{c}\text { Altitude of } \\
\text { water surface } \\
\text { (feet above } \\
\text { sea level) }\end{array}$ & Method & $\begin{array}{l}\text { Site } \\
\text { status }\end{array}$ & $\begin{array}{l}\text { Data } \\
\text { source }\end{array}$ \\
\hline \multirow[t]{14}{*}{$J F-2 a$} & 364938116252102 & UE-25p 1 PTH & $3,655.5$ & 0.63 & $01-22-2003$ & 1445 & $1,184.49$ & $2,471.0$ & $\mathrm{~S}$ & - & EMP \\
\hline & & & & & $02-24-2003$ & 0916 & $1,183.91$ & $2,471.6$ & $\mathrm{~V}$ & - & EMP \\
\hline & & & & & $02-25-2003$ & -- & $1,184.17$ & $2,471.3$ & $\mathrm{~V}$ & - & HRC \\
\hline & & & & & 03-20-2003 & 1158 & $1,184.24$ & $2,471.3$ & $\mathrm{~V}$ & - & EMP \\
\hline & & & & & $04-28-2003$ & 1211 & $1,184.11$ & $2,471.4$ & $\mathrm{~V}$ & - & EMP \\
\hline & & & & & 04-30-2003 & -- & $1,184.51$ & $2,471.0$ & $\mathrm{~V}$ & - & $\mathrm{HRC}$ \\
\hline & & & & & 05-06-2003 & 1529 & $1,184.07$ & $2,471.4$ & $\mathrm{~V}$ & - & EMP \\
\hline & & & & & $06-05-2003$ & 1135 & $1,184.37$ & $2,471.1$ & $\mathrm{~F}$ & - & $\mathrm{HRC}$ \\
\hline & & & & & $07-15-2003$ & 1035 & $1,182.99$ & $2,472.5$ & $\mathrm{~F}$ & - & HRC \\
\hline & & & & & 09-10-2003 & 1135 & $1,182.79$ & $2,472.7$ & $\mathrm{~F}$ & - & HRC \\
\hline & & & & & $10-15-2003$ & 1135 & $1,182.52$ & $2,473.0$ & $\mathrm{~F}$ & - & HRC \\
\hline & & & & & $11-15-2003$ & 1035 & $1,182.45$ & $2,473.0$ & $\mathrm{~F}$ & - & HRC \\
\hline & & & & & $12-10-2003$ & 1035 & $1,182.35$ & $2,473.2$ & $\mathrm{~F}$ & - & HRC \\
\hline & & & & & $12-15-2003$ & 1035 & $1,182.59$ & $2,472.9$ & $\mathrm{~F}$ & - & HRC \\
\hline
\end{tabular}




\begin{tabular}{|c|c|c|c|c|c|c|c|c|c|c|c|}
\hline \multirow[b]{2}{*}{$\begin{array}{c}\text { Site } \\
\text { number } \\
\text { (fig. 1) }\end{array}$} & \multirow[b]{2}{*}{$\begin{array}{l}\text { U.S. Geological } \\
\text { Survey site } \\
\text { identification }\end{array}$} & \multirow[b]{2}{*}{ Site name } & \multirow{2}{*}{$\begin{array}{c}\text { Land- } \\
\text { surface } \\
\text { altitude } \\
\text { (feet above } \\
\text { sea level) }\end{array}$} & \multirow{2}{*}{$\begin{array}{l}\text { Height of } \\
\text { measure- } \\
\text { ment } \\
\text { point (feet } \\
\text { above land } \\
\text { surface) }\end{array}$} & \multicolumn{7}{|c|}{ Water-level measurement } \\
\hline & & & & & Date & Time & $\begin{array}{l}\text { Depth to } \\
\text { water (feet } \\
\text { below land } \\
\text { surface) }\end{array}$ & $\begin{array}{c}\text { Altitude of } \\
\text { water surface } \\
\text { (feet above } \\
\text { sea level) }\end{array}$ & Method & $\begin{array}{c}\text { Site } \\
\text { status }\end{array}$ & $\begin{array}{l}\text { Data } \\
\text { source }\end{array}$ \\
\hline \multirow[t]{19}{*}{$\mathrm{J}-13$} & 364828116234001 & $\mathrm{~J}-13 \mathrm{WW}$ & $3,317.9$ & 1.08 & $01-27-2003$ & 1556 & 927.04 & $2,390.9$ & $\mathrm{~V}$ & - & EMP \\
\hline & & & & & $02-20-2003$ & 1336 & 927.17 & $2,390.7$ & $\mathrm{~V}$ & - & EMP \\
\hline & & & & & $03-06-2003$ & -- & 927.69 & $2,390.2$ & $\mathrm{~V}$ & - & HRC \\
\hline & & & & & 03-20-2003 & 0932 & 927.41 & $2,390.5$ & $\mathrm{~V}$ & - & EMP \\
\hline & & & & & $04-28-2003$ & 0917 & 927.23 & $2,390.7$ & $\mathrm{~V}$ & - & EMP \\
\hline & & & & & 05-06-2003 & 1408 & 927.15 & $2,390.8$ & $\mathrm{~V}$ & - & EMP \\
\hline & & & & & $05-15-2003$ & -- & 927.62 & $2,390.3$ & $\mathrm{~V}$ & - & HRC \\
\hline & & & & & $06-23-2003$ & 1110 & 927.06 & $2,390.8$ & $\mathrm{~V}$ & - & EMP \\
\hline & & & & & 07-07-2003 & 1322 & 927.17 & $2,390.7$ & $\mathrm{~V}$ & - & EMP \\
\hline & & & & & 08-13-2003 & 0919 & 927.25 & $2,390.6$ & $\mathrm{~V}$ & - & EMP \\
\hline & & & & & 09-10-2003 & 1159 & 927.37 & $2,390.5$ & $\mathrm{~V}$ & - & HRC \\
\hline & & & & 0.56 & 09-24-2003 & 1525 & 927.16 & $2,390.7$ & $\mathrm{~V}$ & - & EMP \\
\hline & & & & 0.98 & $10-28-2003$ & 1012 & 927.15 & $2,390.8$ & $\mathrm{~V}$ & - & EMP \\
\hline & & & & & $11-06-2003$ & 0953 & 927.72 & $2,390.2$ & $\mathrm{~V}$ & - & HRC \\
\hline & & & & & $11-06-2003$ & 1419 & 927.39 & $2,390.5$ & $\mathrm{~V}$ & - & EMP \\
\hline & & & & & $11-13-2003$ & 1028 & 927.63 & $2,390.3$ & $\mathrm{~V}$ & - & NTS \\
\hline & & & & & $12-11-2003$ & 0924 & 927.24 & $2,390.7$ & $\mathrm{~F}$ & - & NTS \\
\hline & & & & & $12-23-2003$ & 1305 & 927.28 & $2,390.6$ & $\mathrm{~F}$ & - & NTS \\
\hline & & & & & $12-31-2003$ & 1039 & 927.33 & $2,390.6$ & $\mathrm{~F}$ & - & NTS \\
\hline
\end{tabular}


Table 5. Periodic water-level data at monitoring sites in Yucca Mountain region, 2003-Continued

\begin{tabular}{|c|c|c|c|c|c|c|c|c|c|c|c|}
\hline \multirow[b]{2}{*}{$\begin{array}{c}\text { Site } \\
\text { number } \\
\text { (fig. 1) }\end{array}$} & \multirow[b]{2}{*}{$\begin{array}{l}\text { U.S. Geological } \\
\text { Survey site } \\
\text { identification }\end{array}$} & \multirow[b]{2}{*}{ Site name } & \multirow{2}{*}{$\begin{array}{c}\text { Land- } \\
\text { surface } \\
\text { altitude } \\
\text { (feet above } \\
\text { sea level) }\end{array}$} & \multirow{2}{*}{$\begin{array}{l}\text { Height of } \\
\text { measure- } \\
\text { ment } \\
\text { point (feet } \\
\text { above land } \\
\text { surface) }\end{array}$} & \multicolumn{7}{|c|}{ Water-level measurement } \\
\hline & & & & & Date & Time & $\begin{array}{l}\text { Depth to } \\
\text { water (feet } \\
\text { below land } \\
\text { surface) }\end{array}$ & $\begin{array}{c}\text { Altitude of } \\
\text { water surface } \\
\text { (feet above } \\
\text { sea level) }\end{array}$ & Method & $\begin{array}{l}\text { Site } \\
\text { status }\end{array}$ & $\begin{array}{l}\text { Data } \\
\text { source }\end{array}$ \\
\hline \multirow[t]{17}{*}{$\mathrm{J}-11$} & 364706116170601 & $\mathrm{~J}-11 \mathrm{WW}$ & $3,442.8$ & 2.11 & $01-21-2003$ & 1409 & $1,040.14$ & $2,402.7$ & $\mathrm{~S}$ & - & EMP \\
\hline & & & & & 02-24-2003 & 1000 & $1,039.98$ & $2,402.8$ & $\mathrm{~V}$ & - & EMP \\
\hline & & & & & $03-19-2003$ & -- & $1,040.64$ & $2,402.2$ & $\mathrm{~V}$ & - & HRC \\
\hline & & & & & 03-20-2003 & 1109 & $1,040.29$ & $2,402.5$ & $\mathrm{~V}$ & - & EMP \\
\hline & & & & & 04-28-2003 & 1117 & $1,040.15$ & $2,402.6$ & $\mathrm{~V}$ & - & EMP \\
\hline & & & & & 05-06-2003 & 1205 & $1,040.13$ & $2,402.7$ & $\mathrm{~V}$ & - & EMP \\
\hline & & & & & $05-15-2003$ & -- & $1,040.59$ & $2,402.2$ & $\mathrm{~V}$ & - & HRC \\
\hline & & & & & 06-23-2003 & 1314 & $1,039.95$ & $2,402.8$ & $\mathrm{~V}$ & - & EMP \\
\hline & & & & & 07-07-2003 & 1526 & $1,040.10$ & $2,402.7$ & $\mathrm{~V}$ & - & EMP \\
\hline & & & & & 08-13-2003 & 1135 & $1,040.25$ & $2,402.6$ & $\mathrm{~V}$ & - & EMP \\
\hline & & & & & 08-28-2003 & 1432 & $1,040.16$ & $2,402.6$ & $\mathrm{~V}$ & - & EMP \\
\hline & & & & & $09-10-2003$ & 1245 & $1,040.41$ & $2,402.4$ & V & - & HRC \\
\hline & & & & & 09-24-2003 & 1740 & $1,040.13$ & $2,402.7$ & $\mathrm{~V}$ & - & EMP \\
\hline & & & & & $10-08-2003$ & 1105 & $1,040.21$ & $2,402.6$ & $\mathrm{~S}$ & - & EMP \\
\hline & & & & & 11-06-2003 & 1221 & $1,040.47$ & $2,402.3$ & $\mathrm{~V}$ & - & HRC \\
\hline & & & & & 11-06-2003 & 1322 & $1,040.31$ & $2,402.5$ & $\mathrm{~V}$ & - & EMP \\
\hline & & & & & $12-04-2003$ & 1522 & $1,040.24$ & $2,402.6$ & $\mathrm{~V}$ & - & EMP \\
\hline
\end{tabular}




\begin{tabular}{|c|c|c|c|c|c|c|c|c|c|c|c|}
\hline \multirow[b]{2}{*}{$\begin{array}{c}\text { Site } \\
\text { number } \\
\text { (fig. 1) }\end{array}$} & \multirow[b]{2}{*}{$\begin{array}{l}\text { U.S. Geological } \\
\text { Survey site } \\
\text { identification }\end{array}$} & \multirow[b]{2}{*}{ Site name } & \multirow{2}{*}{$\begin{array}{l}\text { Land- } \\
\text { surface } \\
\text { altitude } \\
\text { (feet above } \\
\text { sea level) }\end{array}$} & \multirow{2}{*}{$\begin{array}{l}\text { Height of } \\
\text { measure- } \\
\text { ment } \\
\text { point (feet } \\
\text { above land } \\
\text { surface) }\end{array}$} & \multicolumn{7}{|c|}{ Water-level measurement } \\
\hline & & & & & Date & Time & $\begin{array}{l}\text { Depth to } \\
\text { water (feet } \\
\text { below land } \\
\text { surface) }\end{array}$ & $\begin{array}{c}\text { Altitude of } \\
\text { water surface } \\
\text { (feet above } \\
\text { sea level) }\end{array}$ & Method & $\begin{array}{l}\text { Site } \\
\text { status }\end{array}$ & $\begin{array}{l}\text { Data } \\
\text { source }\end{array}$ \\
\hline \multirow[t]{19}{*}{$\mathrm{J}-12$} & 364554116232401 & $\mathrm{~J}-12 \mathrm{WW}$ & $3,128.4$ & 3.95 & $01-22-2003$ & 0803 & 739.78 & $2,388.6$ & $\mathrm{~S}$ & - & EMP \\
\hline & & & & & $02-20-2003$ & 1413 & 739.55 & $2,388.8$ & $\mathrm{~V}$ & - & EMP \\
\hline & & & & & 03-06-2003 & -- & 739.98 & $2,388.4$ & $\mathrm{~V}$ & - & HRC \\
\hline & & & & & $03-20-2003$ & 0959 & 739.74 & $2,388.7$ & $\mathrm{~V}$ & - & EMP \\
\hline & & & & & $04-28-2003$ & 0951 & 739.58 & $2,388.8$ & $\mathrm{~V}$ & - & EMP \\
\hline & & & & & $05-06-2003$ & 1324 & 739.47 & $2,388.9$ & $\mathrm{~V}$ & - & EMP \\
\hline & & & & & $05-15-2003$ & -- & 739.76 & $2,388.7$ & $\mathrm{~V}$ & - & $\mathrm{HRC}$ \\
\hline & & & & & $06-23-2003$ & 1146 & 739.43 & $2,389.0$ & $\mathrm{~V}$ & - & EMP \\
\hline & & & & & 07-07-2003 & 1400 & 739.49 & $2,388.9$ & $\mathrm{~V}$ & - & EMP \\
\hline & & & & & 08-13-2003 & 1008 & 739.56 & $2,388.8$ & $\mathrm{~V}$ & - & EMP \\
\hline & & & & & $09-10-2003$ & 0949 & 739.67 & $2,388.7$ & $\mathrm{~V}$ & - & HRC \\
\hline & & & & & 09-24-2003 & 1605 & 739.46 & $2,388.9$ & $\mathrm{~V}$ & - & EMP \\
\hline & & & & & $10-07-2003$ & 1033 & 739.46 & $2,388.9$ & $\mathrm{~S}$ & - & EMP \\
\hline & & & & & $11-06-2003$ & 1036 & 739.72 & $2,388.7$ & $\mathrm{~V}$ & - & HRC \\
\hline & & & & & $11-06-2003$ & 1122 & 739.66 & $2,388.7$ & $\mathrm{~V}$ & - & EMP \\
\hline & & & & & $11-13-2003$ & 1102 & 746.74 & $2,381.7$ & $\mathrm{~V}$ & $\mathrm{P}$ & EMP \\
\hline & & & & & $11-13-2003$ & 1214 & 739.57 & $2,388.8$ & $\mathrm{~V}$ & - & EMP \\
\hline & & & & & $12-04-2003$ & 1555 & 739.48 & $2,388.9$ & $\mathrm{~V}$ & - & EMP \\
\hline & & & & & $12-15-2003$ & 1114 & 740.05 & $2,388.4$ & $\mathrm{~V}$ & - & NTS \\
\hline \multirow[t]{12}{*}{ JF-3 } & 364528116232201 & JF-3 Well & $3,098.3$ & 2.27 & $01-15-2003$ & 1015 & 709.82 & $2,388.5$ & $\mathrm{~V}$ & - & EMP \\
\hline & & & & & $02-20-2003$ & 1430 & 709.54 & $2,388.8$ & $\mathrm{~V}$ & - & EMP \\
\hline & & & & & $03-20-2003$ & 1015 & 709.73 & $2,388.6$ & $\mathrm{~V}$ & - & EMP \\
\hline & & & & & $04-28-2003$ & 1015 & 709.57 & $2,388.7$ & $\mathrm{~V}$ & - & EMP \\
\hline & & & & & 05-06-2003 & 1245 & 709.48 & $2,388.8$ & $\mathrm{~V}$ & - & EMP \\
\hline & & & & & $06-23-2003$ & 1215 & 709.41 & $2,388.9$ & $\mathrm{~V}$ & - & EMP \\
\hline & & & & & 07-07-2003 & 1415 & 709.47 & $2,388.8$ & $\mathrm{~V}$ & - & EMP \\
\hline & & & & & 08-13-2003 & 1030 & 709.58 & $2,388.7$ & $\mathrm{~V}$ & - & EMP \\
\hline & & & & & 09-24-2003 & 1630 & 709.47 & $2,388.8$ & $\mathrm{~V}$ & - & EMP \\
\hline & & & & & $10-27-2003$ & 1130 & 709.55 & $2,388.8$ & $\mathrm{~V}$ & - & EMP \\
\hline & & & & & $11-06-2003$ & 1215 & 709.64 & $2,388.7$ & $\mathrm{~V}$ & - & EMP \\
\hline & & & & & $12-04-2003$ & 1615 & 709.46 & $2,388.8$ & $\mathrm{~V}$ & - & EMP \\
\hline
\end{tabular}


Table 5. Periodic water-level data at monitoring sites in Yucca Mountain region, 2003-Continued

\begin{tabular}{|c|c|c|c|c|c|c|c|c|c|c|c|}
\hline \multirow[b]{2}{*}{$\begin{array}{c}\text { Site } \\
\text { number } \\
\text { (fig. 1) }\end{array}$} & \multirow[b]{2}{*}{$\begin{array}{l}\text { U.S. Geological } \\
\text { Survey site } \\
\text { identification }\end{array}$} & \multirow[b]{2}{*}{ Site name } & \multirow{2}{*}{$\begin{array}{c}\text { Land- } \\
\text { surface } \\
\text { altitude } \\
\text { (feet above } \\
\text { sea level) }\end{array}$} & \multirow{2}{*}{$\begin{array}{l}\text { Height of } \\
\text { measure- } \\
\text { ment } \\
\text { point (feet } \\
\text { above land } \\
\text { surface) }\end{array}$} & \multicolumn{7}{|c|}{ Water-level measurement } \\
\hline & & & & & Date & Time & $\begin{array}{l}\text { Depth to } \\
\text { water (feet } \\
\text { below land } \\
\text { surface) }\end{array}$ & $\begin{array}{c}\text { Altitude of } \\
\text { water surface } \\
\text { (feet above } \\
\text { sea level) }\end{array}$ & Method & $\begin{array}{l}\text { Site } \\
\text { status }\end{array}$ & $\begin{array}{l}\text { Data } \\
\text { source }\end{array}$ \\
\hline \multirow[t]{12}{*}{ RV-1 } & 363815116175901 & TW-5 & $3,056.0$ & 1.6 & $01-27-2003$ & 0951 & 677.63 & $2,378.4$ & $\mathrm{~V}$ & - & EMP \\
\hline & & & & & 02-07-2003 & 0725 & 677.66 & $2,378.3$ & $\mathrm{~V}$ & - & EMP \\
\hline & & & & & $03-12-2003$ & 0730 & 677.53 & $2,378.5$ & $\mathrm{~V}$ & - & EMP \\
\hline & & & & & 04-04-2003 & 0812 & 677.46 & $2,378.5$ & $\mathrm{~V}$ & - & EMP \\
\hline & & & & & $05-20-2003$ & 1744 & 677.33 & $2,378.7$ & $\mathrm{~V}$ & - & EMP \\
\hline & & & & & $06-16-2003$ & 0930 & 677.38 & $2,378.6$ & $\mathrm{~V}$ & - & EMP \\
\hline & & & & & $07-22-2003$ & 1749 & 677.24 & $2,378.8$ & $\mathrm{~V}$ & - & EMP \\
\hline & & & & & 08-28-2003 & 1725 & 677.24 & $2,378.8$ & $\mathrm{~V}$ & - & EMP \\
\hline & & & & & 09-16-2003 & 0945 & 677.30 & $2,378.7$ & $\mathrm{~V}$ & - & EMP \\
\hline & & & & & $10-24-2003$ & 1347 & 677.24 & $2,378.8$ & V & - & EMP \\
\hline & & & & & $11-17-2003$ & 1047 & 677.29 & $2,378.7$ & V & - & EMP \\
\hline & & & & & $12-08-2003$ & 1014 & 677.37 & $2,378.6$ & V & - & EMP \\
\hline \multirow[t]{12}{*}{ MV-1 } & 363530116021401 & Army 1 WW & $3,153.3$ & 3.10 & $01-27-2003$ & 0822 & 786.43 & $2,366.9$ & V & $\mathrm{Z}$ & EMP \\
\hline & & & & & $02-26-2003$ & 0813 & 787.66 & $2,365.6$ & V & $\mathrm{R}$ & EMP \\
\hline & & & & & $03-17-2003$ & 0822 & 786.30 & $2,367.0$ & $\mathrm{~V}$ & $\mathrm{Z}$ & EMP \\
\hline & & & & & $04-21-2003$ & 0820 & 786.43 & $2,366.9$ & V & $\mathrm{Z}$ & EMP \\
\hline & & & & & $05-27-2003$ & 0810 & 786.72 & $2,366.6$ & $\mathrm{~V}$ & $\mathrm{Z}$ & EMP \\
\hline & & & & & $06-23-2003$ & 0802 & 786.56 & $2,366.7$ & V & $\mathrm{Z}$ & EMP \\
\hline & & & & & $07-28-2003$ & 0827 & 786.64 & $2,366.7$ & V & $\mathrm{Z}$ & EMP \\
\hline & & & & & $08-25-2003$ & 0815 & 786.52 & $2,366.8$ & $\mathrm{~V}$ & $\mathrm{Z}$ & EMP \\
\hline & & & & & $09-29-2003$ & 0820 & 786.47 & $2,366.8$ & $\mathrm{~V}$ & $\mathrm{Z}$ & EMP \\
\hline & & & & & $10-27-2003$ & 0817 & 786.66 & $2,366.6$ & $\mathrm{~V}$ & $\mathrm{Z}$ & EMP \\
\hline & & & & & $11-17-2003$ & 0819 & 786.53 & $2,366.8$ & V & $\mathrm{Z}$ & EMP \\
\hline & & & & & $12-08-2003$ & 0812 & 786.46 & $2,366.8$ & V & $\mathrm{Z}$ & EMP \\
\hline
\end{tabular}




\begin{tabular}{|c|c|c|c|c|c|c|c|c|c|c|c|}
\hline \multirow[b]{2}{*}{$\begin{array}{c}\text { Site } \\
\text { number } \\
\text { (fig. 1) }\end{array}$} & \multirow[b]{2}{*}{$\begin{array}{l}\text { U.S. Geological } \\
\text { Survey site } \\
\text { identification }\end{array}$} & \multirow[b]{2}{*}{ Site name } & \multirow{2}{*}{$\begin{array}{c}\text { Land- } \\
\text { surface } \\
\text { altitude } \\
\text { (feet above } \\
\text { sea level) }\end{array}$} & \multirow{2}{*}{$\begin{array}{l}\text { Height of } \\
\text { measure- } \\
\text { ment } \\
\text { point (feet } \\
\text { above land } \\
\text { surface) }\end{array}$} & \multicolumn{7}{|c|}{ Water-level measurement } \\
\hline & & & & & Date & Time & $\begin{array}{l}\text { Depth to } \\
\text { water (feet } \\
\text { below land } \\
\text { surface) }\end{array}$ & $\begin{array}{c}\text { Altitude of } \\
\text { water surface } \\
\text { (feet above } \\
\text { sea level) }\end{array}$ & Method & $\begin{array}{c}\text { Site } \\
\text { status }\end{array}$ & $\begin{array}{l}\text { Data } \\
\text { source }\end{array}$ \\
\hline \multirow[t]{13}{*}{ AD-1 } & 364141116351401 & NA-6 Well BGMW-10 & $2,627.9$ & 1.7 & $01-28-2003$ & 0942 & 269.82 & $2,358.1$ & $\mathrm{~S}$ & - & EMP \\
\hline & & & & & 02-07-2003 & 1219 & 269.85 & $2,358.0$ & $\mathrm{~S}$ & - & EMP \\
\hline & & & & & 03-07-2003 & 0759 & 269.81 & $2,358.1$ & $\mathrm{~S}$ & - & EMP \\
\hline & & & & & 03-11-2003 & -- & 269.73 & $2,358.2$ & $\mathrm{R}$ & - & NPS \\
\hline & & & & & 04-24-2003 & 0833 & 269.84 & $2,358.1$ & $\mathrm{~S}$ & - & EMP \\
\hline & & & & & $05-27-2003$ & 1143 & 269.98 & $2,357.9$ & $\mathrm{~S}$ & - & EMP \\
\hline & & & & & $06-27-2003$ & 1354 & 269.77 & $2,358.1$ & $\mathrm{~S}$ & - & EMP \\
\hline & & & & & $07-28-2003$ & 1148 & 269.83 & $2,358.1$ & $\mathrm{~S}$ & - & EMP \\
\hline & & & & & $08-12-2003$ & 1820 & 269.71 & $2,358.2$ & $\mathrm{~S}$ & - & EMP \\
\hline & & & & & $09-25-2003$ & 1110 & 269.95 & $2,358.0$ & $\mathrm{~S}$ & - & EMP \\
\hline & & & & & $10-24-2003$ & 0740 & 269.89 & $2,358.0$ & $\mathrm{~S}$ & - & EMP \\
\hline & & & & & $11-07-2003$ & 1307 & 269.81 & $2,358.1$ & $\mathrm{~S}$ & - & EMP \\
\hline & & & & & $12-08-2003$ & 1316 & 270.02 & $2,357.9$ & $\mathrm{~S}$ & - & EMP \\
\hline \multirow[t]{12}{*}{$\mathrm{AD}-2$} & 363830116241401 & Airport Well & $2,638.8$ & 1.15 & $01-27-2003$ & 1057 & 325.40 & $2,313.4$ & $\mathrm{~S}$ & - & EMP \\
\hline & & & & & 02-07-2003 & 1026 & 325.61 & $2,313.2$ & $\mathrm{~S}$ & - & EMP \\
\hline & & & & & 03-07-2003 & 1045 & 325.53 & $2,313.3$ & $\mathrm{~S}$ & - & EMP \\
\hline & & & & & 04-04-2003 & 1004 & 325.56 & $2,313.2$ & $\mathrm{~S}$ & - & EMP \\
\hline & & & & & $05-21-2003$ & 1421 & 325.55 & $2,313.2$ & $S$ & - & EMP \\
\hline & & & & & $06-16-2003$ & 1021 & 325.64 & $2,313.2$ & $\mathrm{~S}$ & - & EMP \\
\hline & & & & & $07-23-2003$ & 1422 & 325.65 & $2,313.2$ & $\mathrm{~S}$ & - & EMP \\
\hline & & & & & 08-20-2003 & 0714 & 325.77 & $2,313.0$ & $\mathrm{~S}$ & - & EMP \\
\hline & & & & & $09-25-2003$ & 1312 & 325.69 & $2,313.1$ & $\mathrm{~S}$ & - & EMP \\
\hline & & & & & $10-24-2003$ & 1228 & 325.76 & $2,313.0$ & $S$ & - & EMP \\
\hline & & & & & $11-18-2003$ & 1524 & 325.80 & $2,313.0$ & $\mathrm{~S}$ & - & EMP \\
\hline & & & & & $12-08-2003$ & 1117 & 325.87 & $2,312.9$ & $S$ & - & EMP \\
\hline
\end{tabular}


Table 5. Periodic water-level data at monitoring sites in Yucca Mountain region, 2003-Continued

\begin{tabular}{|c|c|c|c|c|c|c|c|c|c|c|c|}
\hline \multirow[b]{2}{*}{$\begin{array}{c}\text { Site } \\
\text { number } \\
\text { (fig. 1) }\end{array}$} & \multirow[b]{2}{*}{$\begin{array}{l}\text { U.S. Geological } \\
\text { Survey site } \\
\text { identification }\end{array}$} & \multirow[b]{2}{*}{ Site name } & \multirow{2}{*}{$\begin{array}{c}\text { Land- } \\
\text { surface } \\
\text { altitude } \\
\text { (feet above } \\
\text { sea level) }\end{array}$} & \multirow{2}{*}{$\begin{array}{l}\text { Height of } \\
\text { measure- } \\
\text { ment } \\
\text { point (feet } \\
\text { above land } \\
\text { surface) }\end{array}$} & \multicolumn{7}{|c|}{ Water-level measurement } \\
\hline & & & & & Date & Time & $\begin{array}{l}\text { Depth to } \\
\text { water (feet } \\
\text { below land } \\
\text { surface) }\end{array}$ & $\begin{array}{c}\text { Altitude of } \\
\text { water surface } \\
\text { (feet above } \\
\text { sea level) }\end{array}$ & Method & $\begin{array}{l}\text { Site } \\
\text { status }\end{array}$ & $\begin{array}{l}\text { Data } \\
\text { source }\end{array}$ \\
\hline \multirow[t]{12}{*}{$\mathrm{AD}-2 \mathrm{a}$} & 363835116234001 & NDOT Well & $2,656.8$ & 0.4 & 01-16-2003 & 1523 & 342.19 & $2,314.6$ & $\mathrm{~S}$ & - & EMP \\
\hline & & & & & 02-07-2003 & 1005 & 342.40 & $2,314.4$ & $\mathrm{~S}$ & - & EMP \\
\hline & & & & & $03-07-2003$ & 1142 & 342.25 & $2,314.6$ & $\mathrm{~S}$ & - & EMP \\
\hline & & & & & 04-04-2003 & 1039 & 342.38 & $2,314.4$ & $\mathrm{~S}$ & - & EMP \\
\hline & & & & & $05-21-2003$ & 1500 & 342.38 & $2,314.4$ & $\mathrm{~S}$ & - & EMP \\
\hline & & & & & 06-16-2003 & 1121 & 343.20 & $2,313.6$ & $\mathrm{~S}$ & - & EMP \\
\hline & & & & & $07-22-2003$ & 1706 & 342.33 & $2,314.5$ & $\mathrm{~S}$ & - & EMP \\
\hline & & & & & $08-28-2003$ & 1643 & 342.20 & $2,314.6$ & $\mathrm{~S}$ & - & EMP \\
\hline & & & & & 09-25-2003 & 1357 & 342.63 & $2,314.2$ & $\mathrm{~S}$ & - & EMP \\
\hline & & & & & $10-24-2003$ & 1244 & 342.97 & $2,313.8$ & $\mathrm{~S}$ & - & EMP \\
\hline & & & & & $11-18-2003$ & 1541 & 342.46 & $2,314.3$ & $\mathrm{~S}$ & - & EMP \\
\hline & & & & & $12-08-2003$ & 1222 & 342.18 & $2,314.6$ & $\mathrm{~S}$ & - & EMP \\
\hline \multirow[t]{12}{*}{ AD-3a } & 363521116352501 & Amargosa Desert 3a & $2,395.3$ & 1.00 & $01-27-2003$ & 1349 & 133.60 & $2,261.7$ & $\mathrm{~S}$ & - & EMP \\
\hline & & & & & $02-21-2003$ & 1137 & 133.71 & $2,261.6$ & $\mathrm{~S}$ & - & EMP \\
\hline & & & & & $03-27-2003$ & 1301 & 133.78 & $2,261.5$ & $\mathrm{~S}$ & - & EMP \\
\hline & & & & & 04-04-2003 & 1120 & 133.78 & $2,261.5$ & $\mathrm{~S}$ & - & EMP \\
\hline & & & & & $05-21-2003$ & 1601 & 133.88 & $2,261.4$ & $\mathrm{~S}$ & - & EMP \\
\hline & & & & & 06-16-2003 & 1228 & 133.97 & $2,261.3$ & $\mathrm{~S}$ & - & EMP \\
\hline & & & & & $07-23-2003$ & 1510 & 134.02 & $2,261.3$ & $\mathrm{~S}$ & - & EMP \\
\hline & & & & & 08-20-2003 & 0904 & 134.18 & $2,261.1$ & $\mathrm{~S}$ & - & EMP \\
\hline & & & & & $09-29-2003$ & 1614 & 134.19 & $2,261.1$ & $S$ & - & EMP \\
\hline & & & & & $10-24-2003$ & 0905 & 134.30 & $2,261.0$ & $S$ & - & EMP \\
\hline & & & & & $11-18-2003$ & 0725 & 134.35 & $2,261.0$ & $\mathrm{~S}$ & - & EMP \\
\hline & & & & & $12-09-2003$ & 0815 & 134.24 & $2,261.1$ & $S$ & - & EMP \\
\hline
\end{tabular}




\begin{tabular}{|c|c|c|c|c|c|c|c|c|c|c|c|}
\hline \multirow[b]{2}{*}{$\begin{array}{c}\text { Site } \\
\text { number } \\
\text { (fig. 1) }\end{array}$} & \multirow[b]{2}{*}{$\begin{array}{l}\text { U.S. Geological } \\
\text { Survey site } \\
\text { identification }\end{array}$} & \multirow[b]{2}{*}{ Site name } & \multirow{2}{*}{$\begin{array}{c}\text { Land- } \\
\text { surface } \\
\text { altitude } \\
\text { (feet above } \\
\text { sea level) }\end{array}$} & \multirow{2}{*}{$\begin{array}{l}\text { Height of } \\
\text { measure- } \\
\text { ment } \\
\text { point (feet } \\
\text { above land } \\
\text { surface) }\end{array}$} & \multicolumn{7}{|c|}{ Water-level measurement } \\
\hline & & & & & Date & Time & $\begin{array}{l}\text { Depth to } \\
\text { water (feet } \\
\text { below land } \\
\text { surface) }\end{array}$ & $\begin{array}{c}\text { Altitude of } \\
\text { water surface } \\
\text { (feet above } \\
\text { sea level) }\end{array}$ & Method & $\begin{array}{c}\text { Site } \\
\text { status }\end{array}$ & $\begin{array}{l}\text { Data } \\
\text { source }\end{array}$ \\
\hline \multirow[t]{12}{*}{$\mathrm{AD}-4 \mathrm{a}$} & 363428116234701 & Amargosa Desert 4a & $2,477.8$ & 1.0 & $01-27-2003$ & 1121 & 119.58 & $2,358.2$ & $\mathrm{~S}$ & - & EMP \\
\hline & & & & & $02-24-2003$ & 1301 & 119.54 & $2,358.3$ & $\mathrm{~S}$ & - & EMP \\
\hline & & & & & 03-07-2003 & 1215 & 119.63 & $2,358.2$ & $\mathrm{~S}$ & - & EMP \\
\hline & & & & & 04-04-2003 & 1235 & 119.48 & $2,358.3$ & $\mathrm{~S}$ & - & EMP \\
\hline & & & & & $05-21-2003$ & 1356 & 119.64 & $2,358.2$ & $\mathrm{~S}$ & - & EMP \\
\hline & & & & & $06-16-2003$ & 1151 & 119.71 & $2,358.1$ & $\mathrm{~S}$ & - & EMP \\
\hline & & & & & $07-23-2003$ & 1343 & 119.73 & $2,358.1$ & $\mathrm{~S}$ & - & EMP \\
\hline & & & & & 08-20-2003 & 0828 & 119.91 & $2,357.9$ & $\mathrm{~S}$ & - & EMP \\
\hline & & & & & $09-25-2003$ & 1337 & 119.79 & $2,358.0$ & $\mathrm{~S}$ & - & EMP \\
\hline & & & & & $10-24-2003$ & 0947 & 119.89 & $2,357.9$ & $\mathrm{~S}$ & - & EMP \\
\hline & & & & & $11-17-2003$ & 1356 & 119.76 & $2,358.0$ & $\mathrm{~S}$ & - & EMP \\
\hline & & & & & $12-08-2003$ & 1142 & 119.95 & $2,357.8$ & $S$ & - & EMP \\
\hline \multirow[t]{12}{*}{$\mathrm{AD}-5$} & 363310116294001 & USBLM Well & $2,376.4$ & 0.0 & 01-17-2003 & 0912 & 131.30 & $2,245.1$ & $\mathrm{~S}$ & - & EMP \\
\hline & & & & & 02-21-2003 & 1215 & 131.29 & $2,245.1$ & $\mathrm{~S}$ & - & EMP \\
\hline & & & & & 03-26-2003 & 1318 & 131.37 & $2,245.0$ & $\mathrm{~S}$ & - & EMP \\
\hline & & & & & 04-04-2003 & 1200 & 131.44 & $2,245.0$ & $\mathrm{~S}$ & - & EMP \\
\hline & & & & & $05-21-2003$ & 1643 & 131.94 & $2,244.5$ & $\mathrm{~S}$ & - & EMP \\
\hline & & & & & 06-16-2003 & 1306 & 132.29 & $2,244.1$ & $\mathrm{~S}$ & - & EMP \\
\hline & & & & & 07-23-2003 & 1601 & 132.82 & $2,243.6$ & $\mathrm{~S}$ & - & EMP \\
\hline & & & & & 08-20-2003 & 0755 & 133.19 & $2,243.2$ & $\mathrm{~S}$ & - & EMP \\
\hline & & & & & 09-29-2003 & 1520 & 133.72 & $2,242.7$ & $S$ & - & EMP \\
\hline & & & & & $10-14-2003$ & 1559 & 133.95 & $2,242.4$ & $\mathrm{~S}$ & - & EMP \\
\hline & & & & & $11-18-2003$ & 0807 & 134.22 & $2,242.2$ & $\mathrm{~S}$ & - & EMP \\
\hline & & & & & $12-09-2003$ & 0845 & 134.25 & $2,242.2$ & $S$ & - & EMP \\
\hline
\end{tabular}


Table 5. Periodic water-level data at monitoring sites in Yucca Mountain region, 2003-Continued

\begin{tabular}{|c|c|c|c|c|c|c|c|c|c|c|c|}
\hline \multirow[b]{2}{*}{$\begin{array}{c}\text { Site } \\
\text { number } \\
\text { (fig. 1) }\end{array}$} & \multirow[b]{2}{*}{$\begin{array}{l}\text { U.S. Geological } \\
\text { Survey site } \\
\text { identification }\end{array}$} & \multirow[b]{2}{*}{ Site name } & \multirow{2}{*}{$\begin{array}{c}\text { Land- } \\
\text { surface } \\
\text { altitude } \\
\text { (feet above } \\
\text { sea level) }\end{array}$} & \multirow{2}{*}{$\begin{array}{l}\text { Height of } \\
\text { measure- } \\
\text { ment } \\
\text { point (feet } \\
\text { above land } \\
\text { surface) }\end{array}$} & \multicolumn{7}{|c|}{ Water-level measurement } \\
\hline & & & & & Date & Time & $\begin{array}{l}\text { Depth to } \\
\text { water (feet } \\
\text { below land } \\
\text { surface) }\end{array}$ & $\begin{array}{c}\text { Altitude of } \\
\text { water surface } \\
\text { (feet above } \\
\text { sea level) }\end{array}$ & Method & $\begin{array}{l}\text { Site } \\
\text { status }\end{array}$ & $\begin{array}{l}\text { Data } \\
\text { source }\end{array}$ \\
\hline \multirow[t]{12}{*}{ AD-6 } & 363213116133800 & Tracer Well 3 & $2,402.3$ & 0.4 & $01-15-2003$ & 1330 & 41.84 & $2,360.5$ & $\mathrm{~S}$ & - & EMP \\
\hline & & & & & 02-06-2003 & 1630 & 41.82 & $2,360.5$ & $\mathrm{~S}$ & - & EMP \\
\hline & & & & & 03-06-2003 & 1630 & 41.77 & $2,360.5$ & $\mathrm{~S}$ & - & EMP \\
\hline & & & & & 04-03-2003 & 1700 & 41.78 & $2,360.5$ & $\mathrm{~S}$ & - & EMP \\
\hline & & & & & $05-22-2003$ & 1215 & 41.74 & $2,360.6$ & $\mathrm{~S}$ & - & EMP \\
\hline & & & & & 06-13-2003 & 1000 & 41.86 & $2,360.4$ & $\mathrm{~S}$ & - & EMP \\
\hline & & & & & $07-24-2003$ & 1000 & 41.81 & $2,360.5$ & $\mathrm{~S}$ & - & EMP \\
\hline & & & & & $08-28-2003$ & 1830 & 41.71 & $2,360.6$ & $\mathrm{~S}$ & - & EMP \\
\hline & & & & & $09-16-2003$ & 0800 & 41.75 & $2,360.6$ & $\mathrm{~S}$ & - & EMP \\
\hline & & & & & $10-27-2003$ & 1415 & 41.78 & $2,360.5$ & $\mathrm{~S}$ & - & EMP \\
\hline & & & & & $11-07-2003$ & 0800 & 41.87 & $2,360.4$ & $\mathrm{~S}$ & - & EMP \\
\hline & & & & & $12-05-2003$ & 0945 & 41.86 & $2,360.4$ & $\mathrm{~S}$ & - & EMP \\
\hline \multirow[t]{14}{*}{$\mathrm{AD}-7 \mathrm{a}$} & 363009116302702 & Amargosa Desert 7a & $2,305.0$ & 0.78 & $01-27-2003$ & 1315 & 79.04 & $2,226.0$ & $\mathrm{~S}$ & - & EMP \\
\hline & & & & & $02-21-2003$ & 1242 & 78.31 & $2,226.7$ & $\mathrm{~S}$ & - & EMP \\
\hline & & & & & $03-12-2003$ & 0945 & 78.24 & $2,226.8$ & $\mathrm{~S}$ & - & EMP \\
\hline & & & & & $03-27-2003$ & -- & 78.54 & $2,226.5$ & $\mathrm{~T}$ & - & NDWR \\
\hline & & & & & 04-23-2003 & 1455 & 80.18 & $2,224.8$ & $\mathrm{~S}$ & - & EMP \\
\hline & & & & & $05-21-2003$ & 1335 & 81.22 & $2,223.8$ & $\mathrm{~S}$ & - & EMP \\
\hline & & & & & $06-16-2003$ & 1324 & 82.08 & $2,222.9$ & $\mathrm{~S}$ & - & EMP \\
\hline & & & & & $07-23-2003$ & 1253 & 83.11 & $2,221.9$ & $\mathrm{~S}$ & - & EMP \\
\hline & & & & & $08-20-2003$ & 0933 & 84.36 & $2,220.6$ & $\mathrm{~S}$ & - & EMP \\
\hline & & & & & 09-29-2003 & 1434 & 84.14 & $2,220.9$ & $\mathrm{~S}$ & - & EMP \\
\hline & & & & & $10-24-2003$ & 1034 & 84.28 & $2,220.7$ & $\mathrm{~S}$ & - & EMP \\
\hline & & & & & $11-18-2003$ & -- & 82.87 & $2,222.1$ & $\mathrm{~T}$ & - & NDWR \\
\hline & & & & & $11-18-2003$ & 1449 & 82.83 & $2,222.2$ & $\mathrm{~S}$ & - & EMP \\
\hline & & & & & $12-09-2003$ & 0909 & 81.90 & $2,223.1$ & $\mathrm{~S}$ & - & EMP \\
\hline
\end{tabular}




\begin{tabular}{|c|c|c|c|c|c|c|c|c|c|c|c|}
\hline \multirow[b]{2}{*}{$\begin{array}{c}\text { Site } \\
\text { number } \\
\text { (fig. 1) }\end{array}$} & \multirow[b]{2}{*}{$\begin{array}{l}\text { U.S. Geological } \\
\text { Survey site } \\
\text { identification }\end{array}$} & \multirow[b]{2}{*}{ Site name } & \multirow{2}{*}{$\begin{array}{c}\text { Land- } \\
\text { surface } \\
\text { altitude } \\
\text { (feet above } \\
\text { sea level) }\end{array}$} & \multirow{2}{*}{$\begin{array}{l}\text { Height of } \\
\text { measure- } \\
\text { ment } \\
\text { point (feet } \\
\text { above land } \\
\text { surface) }\end{array}$} & \multicolumn{7}{|c|}{ Water-level measurement } \\
\hline & & & & & Date & Time & $\begin{array}{l}\text { Depth to } \\
\text { water (feet } \\
\text { below land } \\
\text { surface) }\end{array}$ & $\begin{array}{c}\text { Altitude of } \\
\text { water surface } \\
\text { (feet above } \\
\text { sea level) }\end{array}$ & Method & $\begin{array}{l}\text { Site } \\
\text { status }\end{array}$ & $\begin{array}{l}\text { Data } \\
\text { source }\end{array}$ \\
\hline \multirow[t]{12}{*}{ AD-8 } & 362929116085701 & Amargosa Desert 8 & $2,394.3$ & 0.60 & $01-27-2003$ & 0901 & 35.30 & $2,359.0$ & $\mathrm{~S}$ & - & EMP \\
\hline & & & & & $02-22-2003$ & 0840 & 35.22 & $2,359.1$ & $\mathrm{~S}$ & - & EMP \\
\hline & & & & & $03-12-2003$ & 0838 & 35.32 & $2,359.0$ & $\mathrm{~S}$ & - & EMP \\
\hline & & & & & 04-04-2003 & 0910 & 35.26 & $2,359.0$ & $\mathrm{~S}$ & - & EMP \\
\hline & & & & & $05-27-2003$ & 0847 & 35.34 & $2,359.0$ & $\mathrm{~S}$ & - & EMP \\
\hline & & & & & $06-16-2003$ & 0831 & 35.51 & $2,358.8$ & $\mathrm{~S}$ & - & EMP \\
\hline & & & & & $07-24-2003$ & 1110 & 35.68 & $2,358.6$ & $\mathrm{~S}$ & - & EMP \\
\hline & & & & & $08-25-2003$ & 0915 & 35.63 & $2,358.7$ & $\mathrm{~S}$ & - & EMP \\
\hline & & & & & 09-29-2003 & 0916 & 35.52 & $2,358.8$ & $\mathrm{~S}$ & - & EMP \\
\hline & & & & & $10-28-2003$ & 1131 & 35.47 & $2,358.8$ & $\mathrm{~S}$ & - & EMP \\
\hline & & & & & $11-17-2003$ & 0930 & 35.39 & $2,358.9$ & $\mathrm{~S}$ & - & EMP \\
\hline & & & & & $12-08-2003$ & 0913 & 35.44 & $2,358.9$ & $\mathrm{~S}$ & - & EMP \\
\hline \multirow[t]{12}{*}{ AD-9a } & 362835116264102 & Amargosa Desert 9a & $2,260.1$ & 0.75 & 01-27-2003 & 1255 & 77.51 & $2,182.6$ & $\mathrm{~S}$ & - & EMP \\
\hline & & & & & 02-21-2003 & 1346 & 77.36 & $2,182.7$ & $\mathrm{~S}$ & - & EMP \\
\hline & & & & 0.40 & 03-26-2003 & 1252 & 80.56 & $2,179.5$ & $\mathrm{~V}$ & - & EMP \\
\hline & & & & & 04-16-2003 & 0933 & 80.34 & $2,179.8$ & $\mathrm{~V}$ & - & EMP \\
\hline & & & & & $05-21-2003$ & 1306 & 81.40 & $2,178.7$ & $\mathrm{~V}$ & - & EMP \\
\hline & & & & & $06-27-2003$ & 1600 & 83.17 & $2,176.9$ & $\mathrm{~V}$ & - & EMP \\
\hline & & & & & 07-23-2003 & 1215 & 83.33 & $2,176.8$ & $\mathrm{~V}$ & $\mathrm{R}$ & EMP \\
\hline & & & & & 08-20-2003 & 1004 & 82.82 & $2,177.3$ & $\mathrm{~V}$ & - & EMP \\
\hline & & & & & $09-25-2003$ & 1537 & 84.64 & $2,175.5$ & $\mathrm{~V}$ & - & EMP \\
\hline & & & & & $10-24-2003$ & 1130 & 84.60 & $2,175.5$ & $\mathrm{~V}$ & - & EMP \\
\hline & & & & & $11-18-2003$ & 1413 & 80.82 & $2,179.3$ & $\mathrm{~V}$ & - & EMP \\
\hline & & & & & $12-09-2003$ & 0940 & 80.01 & $2,180.1$ & $\mathrm{~V}$ & - & EMP \\
\hline
\end{tabular}


Table 5. Periodic water-level data at monitoring sites in Yucca Mountain region, 2003-Continued

\begin{tabular}{|c|c|c|c|c|c|c|c|c|c|c|c|}
\hline \multirow[b]{2}{*}{$\begin{array}{c}\text { Site } \\
\text { number } \\
\text { (fig. 1) }\end{array}$} & \multirow[b]{2}{*}{$\begin{array}{l}\text { U.S. Geological } \\
\text { Survey site } \\
\text { identification }\end{array}$} & \multirow[b]{2}{*}{ Site name } & \multirow{2}{*}{$\begin{array}{c}\text { Land- } \\
\text { surface } \\
\text { altitude } \\
\text { (feet above } \\
\text { sea level) }\end{array}$} & \multirow{2}{*}{$\begin{array}{l}\text { Height of } \\
\text { measure- } \\
\text { ment } \\
\text { point (feet } \\
\text { above land } \\
\text { surface) }\end{array}$} & \multicolumn{7}{|c|}{ Water-level measurement } \\
\hline & & & & & Date & Time & $\begin{array}{l}\text { Depth to } \\
\text { water (feet } \\
\text { below land } \\
\text { surface) }\end{array}$ & $\begin{array}{c}\text { Altitude of } \\
\text { water surface } \\
\text { (feet above } \\
\text { sea level) }\end{array}$ & Method & $\begin{array}{l}\text { Site } \\
\text { status }\end{array}$ & $\begin{array}{l}\text { Data } \\
\text { source }\end{array}$ \\
\hline \multirow[t]{12}{*}{ AD-10 } & 362525116274301 & NA-9 Well & $2,190.9$ & 1.3 & 01-16-2003 & 1040 & 13.73 & $2,177.2$ & $\mathrm{~S}$ & - & EMP \\
\hline & & & & & $02-24-2003$ & 1407 & 13.58 & $2,177.3$ & $\mathrm{~S}$ & - & EMP \\
\hline & & & & & $03-07-2003$ & 1255 & 13.65 & $2,177.2$ & $\mathrm{~S}$ & - & EMP \\
\hline & & & & & 04-03-2003 & 1604 & 13.66 & $2,177.2$ & $\mathrm{~S}$ & - & EMP \\
\hline & & & & & $05-20-2003$ & 1118 & 13.68 & $2,177.2$ & $\mathrm{~S}$ & - & EMP \\
\hline & & & & & $06-16-2003$ & 1510 & 13.71 & $2,177.2$ & $\mathrm{~S}$ & - & EMP \\
\hline & & & & & $07-22-2003$ & 1556 & 13.79 & $2,177.1$ & $\mathrm{~S}$ & - & EMP \\
\hline & & & & & $08-12-2003$ & 1346 & 13.84 & $2,177.1$ & $\mathrm{~S}$ & - & EMP \\
\hline & & & & & 09-29-2003 & 1317 & 13.96 & $2,176.9$ & $\mathrm{~S}$ & - & EMP \\
\hline & & & & & $10-23-2003$ & 1434 & 13.99 & $2,176.9$ & $\mathrm{~S}$ & - & EMP \\
\hline & & & & & $11-19-2003$ & 0847 & 14.01 & $2,176.9$ & $\mathrm{~S}$ & - & EMP \\
\hline & & & & & $12-09-2003$ & 1035 & 13.95 & $2,177.0$ & $\mathrm{~S}$ & - & EMP \\
\hline \multirow[t]{12}{*}{ AD-11 } & 361954116181201 & GS-3 Well & $2,351.3$ & 2.0 & 01-16-2003 & 0918 & 210.04 & $2,141.3$ & $\mathrm{~S}$ & - & EMP \\
\hline & & & & & $02-06-2003$ & 1214 & 209.91 & $2,141.4$ & $\mathrm{~S}$ & - & EMP \\
\hline & & & & & $03-27-2003$ & 1429 & 209.49 & $2,141.8$ & $\mathrm{~S}$ & - & EMP \\
\hline & & & & & 04-04-2003 & 1350 & 209.43 & $2,141.9$ & $\mathrm{~S}$ & - & EMP \\
\hline & & & & & $05-20-2003$ & 1240 & 208.97 & $2,142.3$ & $\mathrm{~S}$ & - & EMP \\
\hline & & & & & $06-12-2003$ & 1658 & 208.48 & $2,142.8$ & $\mathrm{~S}$ & - & EMP \\
\hline & & & & & $07-22-2003$ & 1256 & 208.20 & $2,143.1$ & $\mathrm{~S}$ & - & EMP \\
\hline & & & & & $08-12-2003$ & 1232 & 208.12 & $2,143.2$ & $\mathrm{~S}$ & - & EMP \\
\hline & & & & & $09-15-2003$ & 1257 & 208.12 & $2,143.2$ & $S$ & - & EMP \\
\hline & & & & & $10-23-2003$ & 1246 & 208.46 & $2,142.8$ & $S$ & - & EMP \\
\hline & & & & & $11-19-2003$ & 0809 & 208.78 & $2,142.5$ & $\mathrm{~S}$ & - & EMP \\
\hline & & & & & $12-09-2003$ & 1415 & 208.87 & $2,142.4$ & $S$ & - & EMP \\
\hline
\end{tabular}




\begin{tabular}{|c|c|c|c|c|c|c|c|c|c|c|c|}
\hline \multirow[b]{2}{*}{$\begin{array}{c}\text { Site } \\
\text { number } \\
\text { (fig. 1) }\end{array}$} & \multirow[b]{2}{*}{$\begin{array}{l}\text { U.S. Geological } \\
\text { Survey site } \\
\text { identification }\end{array}$} & \multirow[b]{2}{*}{ Site name } & \multirow{2}{*}{$\begin{array}{c}\text { Land- } \\
\text { surface } \\
\text { altitude } \\
\text { (feet above } \\
\text { sea level) }\end{array}$} & \multirow{2}{*}{$\begin{array}{l}\text { Height of } \\
\text { measure- } \\
\text { ment } \\
\text { point (feet } \\
\text { above land } \\
\text { surface) }\end{array}$} & \multicolumn{7}{|c|}{ Water-level measurement } \\
\hline & & & & & Date & Time & $\begin{array}{l}\text { Depth to } \\
\text { water (feet } \\
\text { below land } \\
\text { surface) }\end{array}$ & $\begin{array}{c}\text { Altitude of } \\
\text { water surface } \\
\text { (feet above } \\
\text { sea level) }\end{array}$ & Method & $\begin{array}{c}\text { Site } \\
\text { status }\end{array}$ & $\begin{array}{l}\text { Data } \\
\text { source }\end{array}$ \\
\hline \multirow[t]{12}{*}{ AD-12 } & 362014116133901 & GS-1 Well & $2,430.3$ & 2.0 & 01-16-2003 & 0834 & 80.92 & $2,349.4$ & $\mathrm{~S}$ & - & EMP \\
\hline & & & & & 02-07-2003 & 1348 & 80.88 & $2,349.4$ & $\mathrm{~S}$ & - & EMP \\
\hline & & & & & 03-06-2003 & 1122 & 80.87 & $2,349.4$ & $\mathrm{~S}$ & - & EMP \\
\hline & & & & & 04-03-2003 & 1118 & 80.87 & $2,349.4$ & $\mathrm{~S}$ & - & EMP \\
\hline & & & & & $05-20-2003$ & 1139 & 80.85 & $2,349.4$ & $\mathrm{~S}$ & - & EMP \\
\hline & & & & & $06-12-2003$ & 1217 & 80.85 & $2,349.4$ & $\mathrm{~S}$ & - & EMP \\
\hline & & & & & $07-22-2003$ & 1159 & 80.89 & $2,349.4$ & $\mathrm{~S}$ & - & EMP \\
\hline & & & & & $08-12-2003$ & 0845 & 80.95 & $2,349.4$ & $\mathrm{~S}$ & - & EMP \\
\hline & & & & & 09-15-2003 & 1207 & 80.94 & $2,349.4$ & $\mathrm{~S}$ & - & EMP \\
\hline & & & & & $10-23-2003$ & 1150 & 81.00 & $2,349.3$ & $\mathrm{~S}$ & - & EMP \\
\hline & & & & & $11-17-2003$ & 1700 & 81.02 & $2,349.3$ & $\mathrm{~S}$ & - & EMP \\
\hline & & & & & $12-05-2003$ & 1452 & 80.99 & $2,349.3$ & $\mathrm{~S}$ & - & EMP \\
\hline \multirow[t]{12}{*}{ AD-13 } & 361724116324201 & S-1 Well & $2,703.2$ & 2.0 & 01-23-2003 & 1225 & 366.61 & $2,336.6$ & $\mathrm{~S}$ & - & EMP \\
\hline & & & & & 02-26-2003 & 1006 & 366.22 & $2,337.0$ & $\mathrm{~S}$ & - & EMP \\
\hline & & & & & $03-12-2003$ & 1057 & 366.34 & $2,336.9$ & $\mathrm{~S}$ & - & EMP \\
\hline & & & & & 04-23-2003 & 1138 & 366.39 & $2,336.8$ & $\mathrm{~S}$ & - & EMP \\
\hline & & & & & $05-20-2003$ & 1353 & 366.38 & $2,336.8$ & $\mathrm{~S}$ & - & EMP \\
\hline & & & & & $06-12-2003$ & 1528 & 366.25 & $2,337.0$ & $\mathrm{~S}$ & - & EMP \\
\hline & & & & & $07-22-2003$ & 1412 & 366.23 & $2,337.0$ & $\mathrm{~S}$ & - & EMP \\
\hline & & & & & 08-19-2003 & 1219 & 366.24 & $2,337.0$ & $\mathrm{~S}$ & - & EMP \\
\hline & & & & & $09-15-2003$ & 1406 & 366.14 & $2,337.1$ & $S$ & - & EMP \\
\hline & & & & & $10-14-2003$ & 1330 & 366.33 & $2,336.9$ & $\mathrm{~S}$ & - & EMP \\
\hline & & & & & $11-18-2003$ & 0908 & 366.39 & $2,336.8$ & $\mathrm{~S}$ & - & EMP \\
\hline & & & & & $12-09-2003$ & 1122 & 366.44 & $2,336.8$ & $S$ & - & EMP \\
\hline
\end{tabular}


Table 5. Periodic water-level data at monitoring sites in Yucca Mountain region, 2003-Continued

\begin{tabular}{|c|c|c|c|c|c|c|c|c|c|c|c|}
\hline \multirow[b]{2}{*}{$\begin{array}{c}\text { Site } \\
\text { number } \\
\text { (fig. 1) }\end{array}$} & \multirow[b]{2}{*}{$\begin{array}{l}\text { U.S. Geological } \\
\text { Survey site } \\
\text { identification }\end{array}$} & \multirow[b]{2}{*}{ Site name } & \multirow{2}{*}{$\begin{array}{c}\text { Land- } \\
\text { surface } \\
\text { altitude } \\
\text { (feet above } \\
\text { sea level) }\end{array}$} & \multirow{2}{*}{$\begin{array}{l}\text { Height of } \\
\text { measure- } \\
\text { ment } \\
\text { point (feet } \\
\text { above land } \\
\text { surface) }\end{array}$} & \multicolumn{7}{|c|}{ Water-level measurement } \\
\hline & & & & & Date & Time & $\begin{array}{l}\text { Depth to } \\
\text { water (feet } \\
\text { below land } \\
\text { surface) }\end{array}$ & $\begin{array}{c}\text { Altitude of } \\
\text { water surface } \\
\text { (feet above } \\
\text { sea level) }\end{array}$ & Method & $\begin{array}{c}\text { Site } \\
\text { status }\end{array}$ & $\begin{array}{l}\text { Data } \\
\text { source }\end{array}$ \\
\hline \multirow[t]{12}{*}{ AD-14 } & 361817116244701 & Death Valley Jct Well & $2,041.8$ & 0.70 & 01-16-2003 & 0950 & 2.48 & $2,039.3$ & $\mathrm{~S}$ & - & EMP \\
\hline & & & & & $02-21-2003$ & 1510 & 2.31 & $2,039.5$ & $\mathrm{~S}$ & - & EMP \\
\hline & & & & & $03-07-2003$ & 1532 & 2.20 & $2,039.6$ & $\mathrm{~S}$ & - & EMP \\
\hline & & & & & 04-04-2003 & 1314 & 2.54 & $2,039.3$ & $\mathrm{~S}$ & - & EMP \\
\hline & & & & & $05-20-2003$ & 1323 & 2.46 & $2,039.3$ & $\mathrm{~S}$ & - & EMP \\
\hline & & & & & $06-12-2003$ & 1616 & 2.29 & $2,039.5$ & $\mathrm{~S}$ & - & EMP \\
\hline & & & & & $07-22-2003$ & 1328 & 2.49 & $2,039.3$ & $\mathrm{~S}$ & - & EMP \\
\hline & & & & & $08-12-2003$ & 1304 & 2.50 & $2,039.3$ & $\mathrm{~S}$ & - & EMP \\
\hline & & & & & 09-15-2003 & 1651 & 2.89 & $2,038.9$ & $\mathrm{~S}$ & - & EMP \\
\hline & & & & & $10-23-2003$ & 1320 & 2.61 & $2,039.2$ & $\mathrm{~S}$ & - & EMP \\
\hline & & & & & $11-18-2003$ & 1223 & 3.12 & $2,038.7$ & $\mathrm{~S}$ & - & EMP \\
\hline & & & & & $12-09-2003$ & 1341 & 2.55 & $2,039.2$ & $\mathrm{~S}$ & - & EMP \\
\hline \multirow[t]{12}{*}{ AM-1 } & 362858116195301 & Rogers Spring Well & $2,265.9$ & 0.14 & 01-16-2003 & 0730 & 2.82 & $2,263.1$ & $\mathrm{~S}$ & - & EMP \\
\hline & & & & & $02-06-2003$ & 1553 & 2.76 & $2,263.1$ & $\mathrm{~S}$ & - & EMP \\
\hline & & & & & $03-06-2003$ & 1522 & 2.64 & $2,263.3$ & $\mathrm{~S}$ & - & EMP \\
\hline & & & & & 04-03-2003 & 1503 & 2.74 & $2,263.2$ & $\mathrm{~S}$ & - & EMP \\
\hline & & & & & $05-22-2003$ & 0750 & 2.95 & $2,263.0$ & $\mathrm{~S}$ & - & EMP \\
\hline & & & & & 06-13-2003 & 1113 & 3.46 & $2,262.4$ & $\mathrm{~S}$ & - & EMP \\
\hline & & & & & $07-23-2003$ & 0656 & 4.16 & $2,261.7$ & $\mathrm{~S}$ & - & EMP \\
\hline & & & & & 08-19-2003 & 0527 & 4.33 & $2,261.6$ & $\mathrm{~S}$ & - & EMP \\
\hline & & & & & $09-29-2003$ & 1101 & 4.27 & $2,261.6$ & $S$ & - & EMP \\
\hline & & & & & $10-14-2003$ & 0823 & 4.04 & $2,261.9$ & $\mathrm{~S}$ & - & EMP \\
\hline & & & & & $11-17-2003$ & 1159 & 3.43 & $2,262.5$ & $\mathrm{~S}$ & - & EMP \\
\hline & & & & & $12-05-2003$ & 1038 & 3.17 & $2,262.7$ & $S$ & - & EMP \\
\hline
\end{tabular}




\begin{tabular}{|c|c|c|c|c|c|c|c|c|c|c|c|}
\hline \multirow[b]{2}{*}{$\begin{array}{c}\text { Site } \\
\text { number } \\
\text { (fig. 1) }\end{array}$} & \multirow[b]{2}{*}{$\begin{array}{l}\text { U.S. Geological } \\
\text { Survey site } \\
\text { identification }\end{array}$} & \multirow[b]{2}{*}{ Site name } & \multirow{2}{*}{$\begin{array}{c}\text { Land- } \\
\text { surface } \\
\text { altitude } \\
\text { (feet above } \\
\text { sea level) }\end{array}$} & \multirow{2}{*}{$\begin{array}{l}\text { Height of } \\
\text { measure- } \\
\text { ment } \\
\text { point (feet } \\
\text { above land } \\
\text { surface) }\end{array}$} & \multicolumn{7}{|c|}{ Water-level measurement } \\
\hline & & & & & Date & Time & $\begin{array}{l}\text { Depth to } \\
\text { water (feet } \\
\text { below land } \\
\text { surface) }\end{array}$ & $\begin{array}{c}\text { Altitude of } \\
\text { water surface } \\
\text { (feet above } \\
\text { sea level) }\end{array}$ & Method & $\begin{array}{l}\text { Site } \\
\text { status }\end{array}$ & $\begin{array}{l}\text { Data } \\
\text { source }\end{array}$ \\
\hline \multirow[t]{12}{*}{ AM-2 } & 362755116190401 & Five Springs Well & $2,367.4$ & 1.17 & $01-16-2003$ & 1221 & 0.31 & $2,367.1$ & $\mathrm{~S}$ & $\mathrm{~F}$ & EMP \\
\hline & & & & & $02-06-2003$ & 1518 & 0.32 & $2,367.1$ & $\mathrm{~S}$ & $\mathrm{~F}$ & EMP \\
\hline & & & & & 03-06-2003 & 1447 & 0.31 & $2,367.1$ & $\mathrm{~S}$ & $\mathrm{~F}$ & EMP \\
\hline & & & & & 04-03-2003 & 1425 & 0.31 & $2,367.1$ & $\mathrm{~S}$ & $\mathrm{~F}$ & EMP \\
\hline & & & & & $05-22-2003$ & 0854 & 0.31 & $2,367.1$ & $\mathrm{~S}$ & $\mathrm{~F}$ & EMP \\
\hline & & & & & $06-13-2003$ & 1227 & 0.31 & $2,367.1$ & $\mathrm{~S}$ & $\mathrm{~F}$ & EMP \\
\hline & & & & & 07-23-2003 & 0752 & 0.30 & $2,367.1$ & $\mathrm{~S}$ & $\mathrm{~F}$ & EMP \\
\hline & & & & & 08-19-2003 & 1658 & 0.29 & $2,367.1$ & $\mathrm{~S}$ & $\mathrm{~F}$ & EMP \\
\hline & & & & & 09-29-2003 & 1217 & 0.30 & $2,367.1$ & $\mathrm{~S}$ & $\mathrm{~F}$ & EMP \\
\hline & & & & & $10-27-2003$ & 1548 & 0.30 & $2,367.1$ & $\mathrm{~S}$ & $\mathrm{~F}$ & EMP \\
\hline & & & & & $11-17-2003$ & 1304 & 0.32 & $2,367.1$ & $\mathrm{~S}$ & $\mathrm{~F}$ & EMP \\
\hline & & & & & $12-05-2003$ & 1159 & 0.32 & $2,367.1$ & $\mathrm{~S}$ & $\mathrm{~F}$ & EMP \\
\hline \multirow[t]{12}{*}{ AM-3 } & 362555116205301 & Ash Meadows 3 & $2,157.0$ & 1.29 & 01-16-2003 & 0752 & 21.43 & $2,135.6$ & $\mathrm{~S}$ & - & EMP \\
\hline & & & & & 02-06-2003 & 1412 & 21.21 & $2,135.8$ & $\mathrm{~S}$ & - & EMP \\
\hline & & & & & 03-06-2003 & 1336 & 20.84 & $2,136.2$ & $\mathrm{~S}$ & - & EMP \\
\hline & & & & & 04-03-2003 & 1323 & 20.61 & $2,136.4$ & $\mathrm{~S}$ & - & EMP \\
\hline & & & & & $05-22-2003$ & 1129 & 20.38 & $2,136.6$ & $\mathrm{~S}$ & - & EMP \\
\hline & & & & & 06-13-2003 & 1315 & 20.49 & $2,136.5$ & $\mathrm{~S}$ & - & EMP \\
\hline & & & & & 07-23-2003 & 1103 & 21.05 & $2,136.0$ & $\mathrm{~S}$ & - & EMP \\
\hline & & & & & 08-19-2003 & 1541 & 21.50 & $2,135.5$ & $\mathrm{~S}$ & - & EMP \\
\hline & & & & & $09-15-2003$ & 1728 & 21.85 & $2,135.2$ & $S$ & - & EMP \\
\hline & & & & & $10-15-2003$ & 0849 & 21.98 & $2,135.0$ & $\mathrm{~S}$ & - & EMP \\
\hline & & & & & $11-17-2003$ & 1423 & 22.02 & $2,135.0$ & $\mathrm{~S}$ & - & EMP \\
\hline & & & & & $12-05-2003$ & 1256 & 22.02 & $2,135.0$ & $\mathrm{~S}$ & - & EMP \\
\hline
\end{tabular}


Table 5. Periodic water-level data at monitoring sites in Yucca Mountain region, 2003_Continued

\begin{tabular}{|c|c|c|c|c|c|c|c|c|c|c|c|}
\hline \multirow[b]{2}{*}{$\begin{array}{c}\text { Site } \\
\text { number } \\
\text { (fig. 1) }\end{array}$} & \multirow[b]{2}{*}{$\begin{array}{l}\text { U.S. Geological } \\
\text { Survey site } \\
\text { identification }\end{array}$} & \multirow[b]{2}{*}{ Site name } & \multirow{2}{*}{$\begin{array}{c}\text { Land- } \\
\text { surface } \\
\text { altitude } \\
\text { (feet above } \\
\text { sea level) }\end{array}$} & \multirow{2}{*}{$\begin{array}{c}\text { Height of } \\
\text { measure- } \\
\text { ment } \\
\text { point (feet } \\
\text { above land } \\
\text { surface) }\end{array}$} & \multicolumn{7}{|c|}{ Water-level measurement } \\
\hline & & & & & Date & Time & $\begin{array}{l}\text { Depth to } \\
\text { water (feet } \\
\text { below land } \\
\text { surface) }\end{array}$ & $\begin{array}{c}\text { Altitude of } \\
\text { water surface } \\
\text { (feet above } \\
\text { sea level) }\end{array}$ & Method & $\begin{array}{l}\text { Site } \\
\text { status }\end{array}$ & $\begin{array}{l}\text { Data } \\
\text { source }\end{array}$ \\
\hline \multirow[t]{25}{*}{ AM-4 } & 362532116172700 & Devils Hole & $2,360.0$ & -- & 08-19-1992 & -- & 2.19 & $2,357.8$ & $\mathrm{~N}$ & - & EMP \\
\hline & & (Altitudes revised from & & & 09-15-1992 & -- & 2.06 & $2,357.9$ & A & - & NPS \\
\hline & & those in previous reports on & & & 10-15-1992 & -- & 2.01 & $2,358.0$ & A & - & NPS \\
\hline & & selected ground-water data & & & 11-18-1992 & 0949 & 1.95 & $2,358.0$ & $\mathrm{~N}$ & - & EMP \\
\hline & & $\begin{array}{l}\text { for the Yucca Mountain } \\
\text { region on the basis of a }\end{array}$ & & & 02-15-1993 & -- & 1.94 & $2,358.1$ & A & - & NPS \\
\hline & & changed measurement point & & & 02-16-1993 & 1613 & 1.86 & $2,358.1$ & $\mathrm{~N}$ & - & EMP \\
\hline & & during May 1992 and sur- & & & 03-15-1993 & -- & 1.90 & $2,358.1$ & $\mathrm{~A}$ & - & NPS \\
\hline & & veys accomplished 1992- & & & 04-15-1993 & -- & 1.88 & $2,358.1$ & $\mathrm{~A}$ & - & NPS \\
\hline & & 2002.) & & & 05-15-1993 & -- & 1.87 & $2,358.1$ & A & - & NPS \\
\hline & & & & & 05-21-1993 & -- & 2.01 & $2,358.0$ & $\mathrm{~N}$ & - & EMP \\
\hline & & & & & 06-15-1993 & -- & 1.87 & $2,358.1$ & A & - & NPS \\
\hline & & & & & 08-15-1993 & -- & 1.89 & $2,358.1$ & A & - & NPS \\
\hline & & & & & 08-25-1993 & 0830 & 1.90 & $2,358.1$ & $\mathrm{~N}$ & - & EMP \\
\hline & & & & & 09-15-1993 & -- & 1.95 & $2,358.0$ & A & - & NPS \\
\hline & & & & & $10-15-1993$ & -- & 1.97 & $2,358.0$ & A & - & NPS \\
\hline & & & & & $11-15-1993$ & -- & 2.00 & $2,358.0$ & A & - & NPS \\
\hline & & & & & $11-17-1993$ & 1148 & 1.95 & $2,358.0$ & $\mathrm{~N}$ & - & EMP \\
\hline & & & & & $12-15-1993$ & -- & 2.02 & $2,358.0$ & $\mathrm{~A}$ & - & NPS \\
\hline & & & & & 02-15-1994 & -- & 2.01 & $2,358.0$ & A & - & NPS \\
\hline & & & & & 02-16-1994 & 1130 & 1.99 & $2,358.0$ & $\mathrm{~N}$ & & EMP \\
\hline & & & & & 03-15-1994 & -- & 1.99 & $2,358.0$ & A & - & NPS \\
\hline & & & & & 04-15-1994 & -- & 1.98 & $2,358.0$ & A & - & NPS \\
\hline & & & & & 05-15-1994 & -- & 2.01 & $2,358.0$ & A & - & NPS \\
\hline & & & & & 05-26-1994 & 1135 & 2.13 & $2,357.9$ & $\mathrm{~N}$ & - & EMP \\
\hline & & & & & 06-15-1994 & -- & 2.02 & $2,358.0$ & A & - & NPS \\
\hline
\end{tabular}




\begin{tabular}{|c|c|c|c|c|c|c|c|c|c|c|c|}
\hline \multirow[b]{2}{*}{$\begin{array}{c}\text { Site } \\
\text { number } \\
\text { (fig. 1) }\end{array}$} & \multirow[b]{2}{*}{$\begin{array}{l}\text { U.S. Geological } \\
\text { Survey site } \\
\text { identification }\end{array}$} & \multirow[b]{2}{*}{ Site name } & \multirow{2}{*}{$\begin{array}{c}\text { Land- } \\
\text { surface } \\
\text { altitude } \\
\text { (feet above } \\
\text { sea level) }\end{array}$} & \multirow{2}{*}{$\begin{array}{l}\text { Height of } \\
\text { measure- } \\
\text { ment } \\
\text { point (feet } \\
\text { above land } \\
\text { surface) }\end{array}$} & \multicolumn{7}{|c|}{ Water-level measurement } \\
\hline & & & & & Date & Time & $\begin{array}{l}\text { Depth to } \\
\text { water (feet } \\
\text { below land } \\
\text { surface) }\end{array}$ & $\begin{array}{c}\text { Altitude of } \\
\text { water surface } \\
\text { (feet above } \\
\text { sea level) }\end{array}$ & Method & $\begin{array}{l}\text { Site } \\
\text { status }\end{array}$ & $\begin{array}{l}\text { Data } \\
\text { source }\end{array}$ \\
\hline \multirow[t]{25}{*}{ AM-4 } & 362532116172700 & Devils Hole & $2,360.0$ & -- & 07-15-1994 & -- & 2.03 & $2,358.0$ & A & - & NPS \\
\hline & & & & & 08-15-1994 & -- & 2.05 & $2,358.0$ & A & - & NPS \\
\hline & & & & & 08-24-1994 & 1300 & 2.09 & $2,357.9$ & $\mathrm{~N}$ & - & EMP \\
\hline & & & & & 10-15-1994 & -- & 2.08 & $2,357.9$ & A & - & NPS \\
\hline & & & & & 11-09-1994 & 1000 & 1.98 & $2,358.0$ & $\mathrm{~N}$ & - & EMP \\
\hline & & & & & 11-15-1994 & -- & 2.10 & $2,357.9$ & A & - & NPS \\
\hline & & & & & $12-15-1994$ & -- & 2.06 & $2,357.9$ & $\mathrm{~A}$ & - & NPS \\
\hline & & & & & 01-15-1995 & -- & 2.06 & $2,357.9$ & A & - & NPS \\
\hline & & & & & 02-15-1995 & -- & 2.02 & $2,358.0$ & A & - & NPS \\
\hline & & & & & 03-15-1995 & -- & 2.02 & $2,358.0$ & A & - & NPS \\
\hline & & & & & 03-27-1995 & 1405 & 1.94 & $2,358.1$ & $\mathrm{~N}$ & - & EMP \\
\hline & & & & & 04-15-1995 & -- & 2.00 & $2,358.0$ & A & - & NPS \\
\hline & & & & & 05-15-1995 & -- & 2.00 & $2,358.0$ & A & - & NPS \\
\hline & & & & & 05-31-1995 & 1045 & 2.10 & $2,357.9$ & $\mathrm{~N}$ & - & EMP \\
\hline & & & & & 06-15-1995 & -- & 2.01 & $2,358.0$ & A & - & NPS \\
\hline & & & & & 07-15-1995 & -- & 2.03 & $2,358.0$ & A & - & NPS \\
\hline & & & & & 08-15-1995 & -- & 2.03 & $2,358.0$ & A & - & NPS \\
\hline & & & & & 08-30-1995 & 1350 & 2.06 & $2,357.9$ & $\mathrm{~N}$ & - & EMP \\
\hline & & & & & $10-15-1995$ & -- & 2.06 & $2,357.9$ & A & - & NPS \\
\hline & & & & & $11-08-1995$ & 1200 & 2.09 & $2,357.9$ & $\mathrm{~N}$ & - & EMP \\
\hline & & & & & 11-15-1995 & -- & 2.09 & $2,357.9$ & A & - & NPS \\
\hline & & & & & $12-15-1995$ & -- & 2.09 & $2,357.9$ & A & - & NPS \\
\hline & & & & & 01-15-1996 & -- & 2.08 & $2,357.9$ & A & - & NPS \\
\hline & & & & & 02-07-1996 & -- & 2.09 & $2,357.9$ & $\mathrm{~N}$ & - & EMP \\
\hline & & & & & 02-13-1996 & -- & 2.08 & $2,357.9$ & $\mathrm{~N}$ & - & EMP \\
\hline
\end{tabular}


Table 5. Periodic water-level data at monitoring sites in Yucca Mountain region, 2003-Continued

\begin{tabular}{|c|c|c|c|c|c|c|c|c|c|c|c|}
\hline \multirow[b]{2}{*}{$\begin{array}{c}\text { Site } \\
\text { number } \\
\text { (fig. 1) }\end{array}$} & \multirow[b]{2}{*}{$\begin{array}{l}\text { U.S. Geological } \\
\text { Survey site } \\
\text { identification }\end{array}$} & \multirow[b]{2}{*}{ Site name } & \multirow{2}{*}{$\begin{array}{l}\text { Land- } \\
\text { surface } \\
\text { altitude } \\
\text { (feet above } \\
\text { sea level) }\end{array}$} & \multirow{2}{*}{$\begin{array}{l}\text { Height of } \\
\text { measure- } \\
\text { ment } \\
\text { point (feet } \\
\text { above land } \\
\text { surface) }\end{array}$} & \multicolumn{7}{|c|}{ Water-level measurement } \\
\hline & & & & & Date & Time & $\begin{array}{l}\text { Depth to } \\
\text { water (feet } \\
\text { below land } \\
\text { surface) }\end{array}$ & $\begin{array}{c}\text { Altitude of } \\
\text { water surface } \\
\text { (feet above } \\
\text { sea level) }\end{array}$ & Method & $\begin{array}{l}\text { Site } \\
\text { status }\end{array}$ & $\begin{array}{l}\text { Data } \\
\text { source }\end{array}$ \\
\hline \multirow[t]{25}{*}{ AM-4 } & 362532116172700 & Devils Hole & $2,360.0$ & -- & 02-15-1996 & -- & 2.07 & $2,357.9$ & A & - & NPS \\
\hline & & & & & 03-15-1996 & -- & 2.05 & $2,358.0$ & A & - & NPS \\
\hline & & & & & 04-15-1996 & -- & 2.06 & $2,357.9$ & A & - & NPS \\
\hline & & & & & 05-07-1996 & 1726 & 2.06 & $2,357.9$ & $\mathrm{~N}$ & - & EMP \\
\hline & & & & & 05-15-1996 & -- & 2.03 & $2,358.0$ & A & - & NPS \\
\hline & & & & & 06-15-1996 & -- & 2.06 & $2,357.9$ & A & - & NPS \\
\hline & & & & & 07-15-1996 & -- & 2.06 & $2,357.9$ & $\mathrm{~A}$ & - & NPS \\
\hline & & & & & 08-15-1996 & -- & 2.08 & $2,357.9$ & $\mathrm{~A}$ & - & NPS \\
\hline & & & & & $08-29-1996$ & 1604 & 2.06 & $2,357.9$ & $\mathrm{~N}$ & - & EMP \\
\hline & & & & & 09-15-1996 & -- & 2.08 & $2,357.9$ & A & - & NPS \\
\hline & & & & & $10-15-1996$ & -- & 2.09 & $2,357.9$ & A & - & NPS \\
\hline & & & & & $11-15-1996$ & -- & 2.12 & $2,357.9$ & A & - & NPS \\
\hline & & & & & $11-21-1996$ & 0926 & 2.10 & $2,357.9$ & $\mathrm{~N}$ & - & EMP \\
\hline & & & & & $12-15-1996$ & -- & 2.11 & $2,357.9$ & A & - & NPS \\
\hline & & & & & 01-15-1997 & -- & 2.11 & $2,357.9$ & A & - & NPS \\
\hline & & & & & 02-15-1997 & -- & 2.09 & $2,357.9$ & A & - & NPS \\
\hline & & & & & 02-26-1997 & 0811 & 2.01 & $2,358.0$ & $\mathrm{~N}$ & - & EMP \\
\hline & & & & & 03-15-1997 & -- & 2.09 & $2,357.9$ & A & - & NPS \\
\hline & & & & & 04-15-1997 & -- & 2.05 & $2,358.0$ & $\mathrm{~A}$ & - & NPS \\
\hline & & & & & 05-15-1997 & 1130 & 2.06 & $2,357.9$ & $\mathrm{~N}$ & - & EMP \\
\hline & & & & & 05-15-1997 & -- & 2.05 & $2,358.0$ & A & - & NPS \\
\hline & & & & & 06-15-1997 & -- & 2.04 & $2,358.0$ & A & - & NPS \\
\hline & & & & & 07-15-1997 & -- & 2.07 & $2,357.9$ & A & - & NPS \\
\hline & & & & & 08-15-1997 & -- & 2.08 & $2,357.9$ & A & - & NPS \\
\hline & & & & & 08-19-1997 & 1105 & 2.16 & $2,357.8$ & $\mathrm{~N}$ & - & EMP \\
\hline
\end{tabular}




\begin{tabular}{|c|c|c|c|c|c|c|c|c|c|c|c|}
\hline \multirow[b]{2}{*}{$\begin{array}{c}\text { Site } \\
\text { number } \\
\text { (fig. 1) }\end{array}$} & \multirow[b]{2}{*}{$\begin{array}{l}\text { U.S. Geological } \\
\text { Survey site } \\
\text { identification }\end{array}$} & \multirow[b]{2}{*}{ Site name } & \multirow{2}{*}{$\begin{array}{c}\text { Land- } \\
\text { surface } \\
\text { altitude } \\
\text { (feet above } \\
\text { sea level) }\end{array}$} & \multirow{2}{*}{$\begin{array}{l}\text { Height of } \\
\text { measure- } \\
\text { ment } \\
\text { point (feet } \\
\text { above land } \\
\text { surface) }\end{array}$} & \multicolumn{7}{|c|}{ Water-level measurement } \\
\hline & & & & & Date & Time & $\begin{array}{l}\text { Depth to } \\
\text { water (feet } \\
\text { below land } \\
\text { surface) }\end{array}$ & $\begin{array}{c}\text { Altitude of } \\
\text { water surface } \\
\text { (feet above } \\
\text { sea level) }\end{array}$ & Method & $\begin{array}{l}\text { Site } \\
\text { status }\end{array}$ & $\begin{array}{l}\text { Data } \\
\text { source }\end{array}$ \\
\hline \multirow[t]{25}{*}{ AM-4 } & 362532116172700 & Devils Hole & $2,360.0$ & -- & 09-15-1997 & -- & 2.07 & $2,357.9$ & A & - & NPS \\
\hline & & & & & $10-15-1997$ & -- & 2.09 & $2,357.9$ & A & - & NPS \\
\hline & & & & & $11-15-1997$ & -- & 2.08 & $2,357.9$ & A & - & NPS \\
\hline & & & & & $11-18-1997$ & 1240 & 2.07 & $2,357.9$ & $\mathrm{~N}$ & - & EMP \\
\hline & & & & & $12-15-1997$ & -- & 2.10 & $2,357.9$ & $\mathrm{~A}$ & - & NPS \\
\hline & & & & & 01-15-1998 & -- & 2.07 & $2,357.9$ & A & - & NPS \\
\hline & & & & & 02-15-1998 & -- & 2.03 & $2,358.0$ & $\mathrm{~A}$ & - & NPS \\
\hline & & & & & 02-27-1998 & 0857 & 2.08 & $2,357.9$ & $\mathrm{~N}$ & - & EMP \\
\hline & & & & & 03-15-1998 & -- & 2.01 & $2,358.0$ & A & - & NPS \\
\hline & & & & & 04-15-1998 & -- & 2.04 & $2,358.0$ & A & - & NPS \\
\hline & & & & & 05-15-1998 & -- & 2.01 & $2,358.0$ & A & - & NPS \\
\hline & & & & & 05-27-1998 & 1131 & 2.16 & $2,357.8$ & $\mathrm{~N}$ & - & EMP \\
\hline & & & & & 06-15-1998 & -- & 2.01 & $2,358.0$ & A & - & NPS \\
\hline & & & & & 08-05-1998 & 0915 & 2.16 & $2,357.8$ & $\mathrm{~N}$ & - & EMP \\
\hline & & & & & 08-15-1998 & -- & 2.03 & $2,358.0$ & A & - & NPS \\
\hline & & & & & 09-15-1998 & -- & 2.01 & $2,358.0$ & A & - & NPS \\
\hline & & & & & $10-15-1998$ & -- & 2.05 & $2,358.0$ & A & - & NPS \\
\hline & & & & & $11-15-1998$ & -- & 2.07 & $2,357.9$ & A & - & NPS \\
\hline & & & & & $12-15-1998$ & -- & 2.08 & $2,357.9$ & A & - & NPS \\
\hline & & & & & 01-05-1999 & 0713 & 2.01 & $2,358.0$ & $\mathrm{R}$ & - & NPS \\
\hline & & & & & 02-04-1999 & 0733 & 1.87 & $2,358.1$ & $\mathrm{R}$ & - & NPS \\
\hline & & & & & 03-02-1999 & 0742 & 1.95 & $2,358.0$ & $\mathrm{R}$ & - & NPS \\
\hline & & & & & 04-06-1999 & 0553 & 1.93 & $2,358.1$ & $\mathrm{R}$ & - & NPS \\
\hline & & & & & 04-11-1999 & 0915 & 1.98 & $2,358.0$ & $\mathrm{R}$ & - & NPS \\
\hline & & & & & 05-04-1999 & 0548 & 1.93 & $2,358.1$ & $\mathrm{R}$ & - & NPS \\
\hline
\end{tabular}


Table 5. Periodic water-level data at monitoring sites in Yucca Mountain region, 2003 - Continued

\begin{tabular}{|c|c|c|c|c|c|c|c|c|c|c|c|}
\hline \multirow[b]{2}{*}{$\begin{array}{c}\text { Site } \\
\text { number } \\
\text { (fig. 1) }\end{array}$} & \multirow[b]{2}{*}{$\begin{array}{l}\text { U.S. Geological } \\
\text { Survey site } \\
\text { identification }\end{array}$} & \multirow[b]{2}{*}{ Site name } & \multirow{2}{*}{$\begin{array}{c}\text { Land- } \\
\text { surface } \\
\text { altitude } \\
\text { (feet above } \\
\text { sea level) }\end{array}$} & \multirow{2}{*}{$\begin{array}{l}\text { Height of } \\
\text { measure- } \\
\text { ment } \\
\text { point (feet } \\
\text { above land } \\
\text { surface) }\end{array}$} & \multicolumn{7}{|c|}{ Water-level measurement } \\
\hline & & & & & Date & Time & $\begin{array}{l}\text { Depth to } \\
\text { water (feet } \\
\text { below land } \\
\text { surface) }\end{array}$ & $\begin{array}{c}\text { Altitude of } \\
\text { water surface } \\
\text { (feet above } \\
\text { sea level) }\end{array}$ & Method & $\begin{array}{l}\text { Site } \\
\text { status }\end{array}$ & $\begin{array}{l}\text { Data } \\
\text { source }\end{array}$ \\
\hline \multirow[t]{25}{*}{ AM-4 } & 362532116172700 & Devils Hole & $2,360.0$ & -- & 05-19-1999 & 0538 & 1.88 & $2,358.1$ & $\mathrm{R}$ & - & NPS \\
\hline & & & & & 06-01-1999 & 0535 & 1.89 & $2,358.1$ & $\mathrm{R}$ & - & NPS \\
\hline & & & & & 06-16-1999 & 0543 & 1.88 & $2,358.1$ & $\mathrm{R}$ & - & NPS \\
\hline & & & & & 07-06-1999 & 0730 & 2.02 & $2,358.0$ & $\mathrm{R}$ & - & NPS \\
\hline & & & & & 08-03-1999 & 0618 & 2.01 & $2,358.0$ & $\mathrm{R}$ & - & NPS \\
\hline & & & & & 08-18-1999 & 1112 & 1.89 & $2,358.1$ & $\mathrm{~S}$ & - & EMP \\
\hline & & & & & 09-01-1999 & 0559 & 1.90 & $2,358.1$ & $\mathrm{R}$ & - & NPS \\
\hline & & & & & 10-01-1999 & 0732 & 1.89 & $2,358.1$ & $\mathrm{R}$ & - & NPS \\
\hline & & & & & 10-19-1999 & 0631 & 2.22 & $2,357.8$ & $\mathrm{R}$ & - & NPS \\
\hline & & & & & 11-02-1999 & 0723 & 2.22 & $2,357.8$ & $\mathrm{R}$ & - & NPS \\
\hline & & & & & 12-01-1999 & 0714 & 2.11 & $2,357.9$ & $\mathrm{R}$ & - & NPS \\
\hline & & & & & 01-04-2000 & 0732 & 2.11 & $2,357.9$ & $\mathrm{R}$ & - & NPS \\
\hline & & & & & 02-01-2000 & 0719 & 2.14 & $2,357.9$ & $\mathrm{R}$ & - & NPS \\
\hline & & & & & 03-01-2000 & 0823 & 2.06 & $2,357.9$ & $\mathrm{R}$ & - & NPS \\
\hline & & & & & 04-04-2000 & 0636 & 2.12 & $2,357.9$ & $\mathrm{R}$ & - & NPS \\
\hline & & & & & 04-19-2000 & 0920 & 2.19 & $2,357.8$ & $\mathrm{R}$ & - & NPS \\
\hline & & & & & 05-02-2000 & 0537 & 1.96 & $2,358.0$ & $\mathrm{R}$ & - & NPS \\
\hline & & & & & $05-16-2000$ & 0516 & 2.02 & $2,358.0$ & $\mathrm{R}$ & - & NPS \\
\hline & & & & & $05-31-2000$ & 0519 & 2.02 & $2,358.0$ & $\mathrm{R}$ & - & NPS \\
\hline & & & & & 07-05-2000 & 0622 & 2.01 & $2,358.0$ & $\mathrm{R}$ & - & NPS \\
\hline & & & & & 07-18-2000 & 0712 & 2.10 & $2,357.9$ & $\mathrm{R}$ & - & NPS \\
\hline & & & & & $08-01-2000$ & 0616 & 2.01 & $2,358.0$ & $\mathrm{R}$ & - & NPS \\
\hline & & & & & 08-09-2000 & 0809 & 2.17 & $2,357.8$ & $\mathrm{R}$ & - & NPS \\
\hline & & & & & $08-15-2000$ & 0604 & 2.05 & $2,358.0$ & $\mathrm{R}$ & - & NPS \\
\hline & & & & & 09-05-2000 & 0708 & 2.14 & $2,357.9$ & $\mathrm{R}$ & - & NPS \\
\hline
\end{tabular}




\begin{tabular}{|c|c|c|c|c|c|c|c|c|c|c|c|}
\hline \multirow[b]{2}{*}{$\begin{array}{c}\text { Site } \\
\text { number } \\
\text { (fig. 1) }\end{array}$} & \multirow[b]{2}{*}{$\begin{array}{l}\text { U.S. Geological } \\
\text { Survey site } \\
\text { identification }\end{array}$} & \multirow[b]{2}{*}{ Site name } & \multirow{2}{*}{$\begin{array}{c}\text { Land- } \\
\text { surface } \\
\text { altitude } \\
\text { (feet above } \\
\text { sea level) }\end{array}$} & \multirow{2}{*}{$\begin{array}{l}\text { Height of } \\
\text { measure- } \\
\text { ment } \\
\text { point (feet } \\
\text { above land } \\
\text { surface) }\end{array}$} & \multicolumn{7}{|c|}{ Water-level measurement } \\
\hline & & & & & Date & Time & $\begin{array}{l}\text { Depth to } \\
\text { water (feet } \\
\text { below land } \\
\text { surface) }\end{array}$ & $\begin{array}{c}\text { Altitude of } \\
\text { water surface } \\
\text { (feet above } \\
\text { sea level) }\end{array}$ & Method & $\begin{array}{c}\text { Site } \\
\text { status }\end{array}$ & $\begin{array}{l}\text { Data } \\
\text { source }\end{array}$ \\
\hline \multirow[t]{25}{*}{ AM-4 } & 362532116172700 & Devils Hole & $2,360.0$ & -- & 09-12-2000 & 0657 & 2.12 & $2,357.9$ & $\mathrm{R}$ & - & NPS \\
\hline & & & & & 09-18-2000 & 0729 & 2.06 & $2,357.9$ & $\mathrm{R}$ & - & NPS \\
\hline & & & & & $10-02-2000$ & 0759 & 2.03 & $2,358.0$ & $\mathrm{R}$ & - & NPS \\
\hline & & & & & $10-04-2000$ & 0716 & 2.08 & $2,357.9$ & $\mathrm{R}$ & - & NPS \\
\hline & & & & & $10-16-2000$ & 0754 & 2.06 & $2,357.9$ & $\mathrm{R}$ & - & NPS \\
\hline & & & & & $11-01-2000$ & 0804 & 2.13 & $2,357.9$ & $\mathrm{R}$ & - & NPS \\
\hline & & & & & $11-20-2000$ & 0803 & 2.23 & $2,357.8$ & $\mathrm{R}$ & - & NPS \\
\hline & & & & & $12-04-2000$ & 0801 & 2.18 & $2,357.8$ & $\mathrm{R}$ & - & NPS \\
\hline & & & & & $12-18-2000$ & 0934 & 2.24 & $2,357.8$ & $\mathrm{R}$ & - & NPS \\
\hline & & & & & 01-02-2001 & 0946 & 2.17 & $2,357.8$ & $\mathrm{R}$ & - & NPS \\
\hline & & & & & $01-17-2001$ & 1200 & 2.13 & $2,357.9$ & $\mathrm{R}$ & - & NPS \\
\hline & & & & & 02-01-2001 & 0845 & 2.14 & $2,357.9$ & $\mathrm{R}$ & - & NPS \\
\hline & & & & & 02-16-2001 & 1002 & 2.14 & $2,357.9$ & $\mathrm{R}$ & - & NPS \\
\hline & & & & & 03-03-2001 & 0923 & 2.05 & $2,358.0$ & $\mathrm{R}$ & - & NPS \\
\hline & & & & & 03-12-2001 & 1030 & 2.18 & $2,357.8$ & $\mathrm{R}$ & - & NPS \\
\hline & & & & & 04-02-2001 & 0720 & 1.97 & $2,358.0$ & $\mathrm{R}$ & - & NPS \\
\hline & & & & & $04-17-2001$ & 1102 & 2.09 & $2,357.9$ & $\mathrm{R}$ & - & NPS \\
\hline & & & & & 04-20-2001 & 1235 & 2.06 & $2,357.9$ & $\mathrm{R}$ & - & NPS \\
\hline & & & & & 05-01-2001 & 1008 & 2.01 & $2,358.0$ & $\mathrm{R}$ & - & NPS \\
\hline & & & & & $05-15-2001$ & 1146 & 2.05 & $2,358.0$ & $\mathrm{R}$ & - & NPS \\
\hline & & & & & 06-02-2001 & 0903 & 2.13 & $2,357.9$ & $\mathrm{R}$ & - & NPS \\
\hline & & & & & $07-02-2001$ & 0806 & 2.20 & $2,357.8$ & $\mathrm{R}$ & - & NPS \\
\hline & & & & & 07-16-2001 & 0720 & 2.20 & $2,357.8$ & $\mathrm{R}$ & - & NPS \\
\hline & & & & & 08-01-2001 & 0707 & 2.27 & $2,357.7$ & $\mathrm{R}$ & - & NPS \\
\hline & & & & & 08-02-2001 & 0708 & 2.20 & $2,357.8$ & $\mathrm{R}$ & - & NPS \\
\hline
\end{tabular}


Table 5. Periodic water-level data at monitoring sites in Yucca Mountain region, 2003_Continued

\begin{tabular}{|c|c|c|c|c|c|c|c|c|c|c|c|}
\hline \multirow[b]{2}{*}{$\begin{array}{c}\text { Site } \\
\text { number } \\
\text { (fig. 1) }\end{array}$} & \multirow[b]{2}{*}{$\begin{array}{l}\text { U.S. Geological } \\
\text { Survey site } \\
\text { identification }\end{array}$} & \multirow[b]{2}{*}{ Site name } & \multirow{2}{*}{$\begin{array}{c}\text { Land- } \\
\text { surface } \\
\text { altitude } \\
\text { (feet above } \\
\text { sea level) }\end{array}$} & \multirow{2}{*}{$\begin{array}{l}\text { Height of } \\
\text { measure- } \\
\text { ment } \\
\text { point (feet } \\
\text { above land } \\
\text { surface) }\end{array}$} & \multicolumn{7}{|c|}{ Water-level measurement } \\
\hline & & & & & Date & Time & $\begin{array}{l}\text { Depth to } \\
\text { water (feet } \\
\text { below land } \\
\text { surface) }\end{array}$ & $\begin{array}{c}\text { Altitude of } \\
\text { water surface } \\
\text { (feet above } \\
\text { sea level) }\end{array}$ & Method & $\begin{array}{l}\text { Site } \\
\text { status }\end{array}$ & $\begin{array}{l}\text { Data } \\
\text { source }\end{array}$ \\
\hline \multirow[t]{25}{*}{ AM-4 } & 362532116172700 & Devils Hole & $2,360.0$ & -- & 08-20-2001 & 0832 & 2.11 & $2,357.9$ & $\mathrm{R}$ & - & NPS \\
\hline & & & & & 09-05-2001 & 0955 & 2.11 & $2,357.9$ & $\mathrm{R}$ & - & NPS \\
\hline & & & & & 09-17-2001 & 0805 & 2.13 & $2,357.9$ & $\mathrm{R}$ & - & NPS \\
\hline & & & & & $10-01-2001$ & 0900 & 2.23 & $2,357.8$ & $\mathrm{R}$ & - & NPS \\
\hline & & & & & $10-16-2001$ & 0844 & 2.20 & $2,357.8$ & $\mathrm{R}$ & - & NPS \\
\hline & & & & & $11-01-2001$ & 1401 & 2.12 & $2,357.9$ & $\mathrm{R}$ & - & NPS \\
\hline & & & & & $11-15-2001$ & 1404 & 2.09 & $2,357.9$ & $\mathrm{R}$ & - & NPS \\
\hline & & & & & $12-03-2001$ & 1152 & 2.08 & $2,357.9$ & $\mathrm{R}$ & - & NPS \\
\hline & & & & & $12-13-2001$ & 1440 & 2.11 & $2,357.9$ & $\mathrm{R}$ & - & NPS \\
\hline & & & & & 01-02-2002 & 0821 & 2.07 & $2,357.9$ & $\mathrm{R}$ & - & NPS \\
\hline & & & & & 01-16-2002 & 0845 & 2.12 & $2,357.9$ & $\mathrm{R}$ & - & NPS \\
\hline & & & & & $02-01-2002$ & 0913 & 2.14 & $2,357.9$ & $\mathrm{R}$ & - & NPS \\
\hline & & & & & $02-15-2002$ & 0939 & 2.17 & $2,357.8$ & $\mathrm{R}$ & - & NPS \\
\hline & & & & & 03-04-2002 & 0939 & 2.16 & $2,357.8$ & $\mathrm{R}$ & - & NPS \\
\hline & & & & & 03-15-2002 & 0900 & 2.16 & $2,357.8$ & $\mathrm{R}$ & - & NPS \\
\hline & & & & & 04-01-2002 & 0925 & 2.09 & $2,357.9$ & $\mathrm{R}$ & - & NPS \\
\hline & & & & & 04-20-2002 & 0704 & 2.14 & $2,357.9$ & $\mathrm{R}$ & - & NPS \\
\hline & & & & & 05-01-2002 & 0729 & 2.10 & $2,357.9$ & $\mathrm{R}$ & - & NPS \\
\hline & & & & & 05-14-2002 & 1041 & 2.18 & $2,357.8$ & $\mathrm{R}$ & - & NPS \\
\hline & & & & & 06-01-2002 & 0854 & 2.05 & $2,358.0$ & $\mathrm{R}$ & - & NPS \\
\hline & & & & & $06-17-2002$ & 0748 & 2.15 & $2,357.8$ & $\mathrm{R}$ & - & NPS \\
\hline & & & & & 07-01-2002 & 0746 & 2.13 & $2,357.9$ & $\mathrm{R}$ & - & NPS \\
\hline & & & & & 07-19-2002 & 0718 & 2.22 & $2,357.8$ & $\mathrm{R}$ & - & NPS \\
\hline & & & & & 08-02-2002 & 0809 & 2.15 & $2,357.8$ & $\mathrm{R}$ & - & NPS \\
\hline & & & & & $08-16-2002$ & 0732 & 2.21 & $2,357.8$ & $\mathrm{R}$ & - & NPS \\
\hline
\end{tabular}




\begin{tabular}{|c|c|c|c|c|c|c|c|c|c|c|c|}
\hline \multirow[b]{2}{*}{$\begin{array}{c}\text { Site } \\
\text { number } \\
\text { (fig. 1) }\end{array}$} & \multirow[b]{2}{*}{$\begin{array}{l}\text { U.S. Geological } \\
\text { Survey site } \\
\text { identification }\end{array}$} & \multirow[b]{2}{*}{ Site name } & \multirow{2}{*}{$\begin{array}{c}\text { Land- } \\
\text { surface } \\
\text { altitude } \\
\text { (feet above } \\
\text { sea level) }\end{array}$} & \multirow{2}{*}{$\begin{array}{l}\text { Height of } \\
\text { measure- } \\
\text { ment } \\
\text { point (feet } \\
\text { above land } \\
\text { surface) }\end{array}$} & \multicolumn{7}{|c|}{ Water-level measurement } \\
\hline & & & & & Date & Time & $\begin{array}{l}\text { Depth to } \\
\text { water (feet } \\
\text { below land } \\
\text { surface) }\end{array}$ & $\begin{array}{c}\text { Altitude of } \\
\text { water surface } \\
\text { (feet above } \\
\text { sea level) }\end{array}$ & Method & $\begin{array}{l}\text { Site } \\
\text { status }\end{array}$ & $\begin{array}{l}\text { Data } \\
\text { source }\end{array}$ \\
\hline \multirow[t]{31}{*}{ AM-4 } & 362532116172700 & Devils Hole & $2,360.0$ & -- & 09-01-2002 & 0809 & 2.25 & $2,357.8$ & $\mathrm{R}$ & - & NPS \\
\hline & & & & & 09-16-2002 & 0754 & 2.19 & $2,357.8$ & $\mathrm{R}$ & - & NPS \\
\hline & & & & & $10-04-2002$ & 0855 & 2.30 & $2,357.7$ & $\mathrm{R}$ & - & NPS \\
\hline & & & & & $10-18-2002$ & 0731 & 2.19 & $2,357.8$ & $\mathrm{R}$ & - & NPS \\
\hline & & & & & 11-01-2002 & 1228 & 2.16 & $2,357.8$ & $\mathrm{R}$ & - & NPS \\
\hline & & & & & $11-15-2002$ & 0746 & 2.30 & $2,357.7$ & $\mathrm{R}$ & - & NPS \\
\hline & & & & & $12-01-2002$ & 0957 & 2.19 & $2,357.8$ & $\mathrm{R}$ & - & NPS \\
\hline & & & & & $12-17-2002$ & 0957 & 2.04 & $2,358.0$ & $\mathrm{R}$ & - & NPS \\
\hline & & & & & 01-04-2003 & 1136 & 2.10 & $2,357.9$ & $\mathrm{R}$ & - & NPS \\
\hline & & & & & 01-14-2003 & 0908 & 2.11 & $2,357.9$ & $\mathrm{R}$ & - & NPS \\
\hline & & & & & $01-22-2003$ & 1408 & 2.15 & $2,357.8$ & $\mathrm{R}$ & - & NPS \\
\hline & & & & & 02-03-2003 & 0949 & 2.12 & $2,357.9$ & $\mathrm{R}$ & - & NPS \\
\hline & & & & & $02-18-2003$ & 1011 & 2.11 & $2,357.9$ & $\mathrm{R}$ & - & NPS \\
\hline & & & & & $02-28-2003$ & 0839 & 2.07 & $2,357.9$ & $\mathrm{R}$ & - & NPS \\
\hline & & & & & $03-15-2003$ & 0853 & 2.00 & $2,358.0$ & $\mathrm{R}$ & - & NPS \\
\hline & & & & & 04-01-2003 & 1335 & 1.98 & $2,358.0$ & $\mathrm{R}$ & - & NPS \\
\hline & & & & & $04-15-2003$ & 1105 & 2.24 & $2,357.8$ & $\mathrm{R}$ & - & NPS \\
\hline & & & & & $05-02-2003$ & 0811 & 2.07 & $2,357.9$ & $\mathrm{R}$ & - & NPS \\
\hline & & & & & $05-16-2003$ & 0701 & 2.08 & $2,357.9$ & $\mathrm{R}$ & - & NPS \\
\hline & & & & & 05-29-2003 & 1225 & 2.10 & $2,357.9$ & $\mathrm{R}$ & - & NPS \\
\hline & & & & & $06-16-2003$ & 0649 & 2.03 & $2,358.0$ & $\mathrm{R}$ & - & NPS \\
\hline & & & & & 07-01-2003 & 0549 & 2.03 & $2,358.0$ & $\mathrm{R}$ & - & NPS \\
\hline & & & & & $07-16-2003$ & 0649 & 2.04 & $2,358.0$ & $\mathrm{R}$ & - & NPS \\
\hline & & & & & $07-31-2003$ & 0542 & 2.07 & $2,357.9$ & $\mathrm{R}$ & - & NPS \\
\hline & & & & & $08-14-2003$ & 0620 & 2.05 & $2,358.0$ & $\mathrm{R}$ & - & NPS \\
\hline & & & & & 09-02-2003 & 0605 & 2.20 & $2,357.8$ & $\mathrm{R}$ & - & NPS \\
\hline & & & & & $10-01-2003$ & 0715 & 2.16 & $2,357.8$ & $\mathrm{R}$ & - & NPS \\
\hline & & & & & $10-15-2003$ & 1140 & 2.10 & $2,357.9$ & $\mathrm{R}$ & - & NPS \\
\hline & & & & & $10-30-2003$ & 0703 & 1.99 & $2,358.0$ & $\mathrm{R}$ & - & NPS \\
\hline & & & & & $11-17-2003$ & 0826 & 2.20 & $2,357.8$ & $\mathrm{R}$ & - & NPS \\
\hline & & & & & $12-03-2003$ & 1534 & 2.07 & $2,357.9$ & $\mathrm{R}$ & - & NPS \\
\hline
\end{tabular}


Table 5. Periodic water-level data at monitoring sites in Yucca Mountain region, 2003-Continued

\begin{tabular}{|c|c|c|c|c|c|c|c|c|c|c|c|}
\hline \multirow[b]{2}{*}{$\begin{array}{c}\text { Site } \\
\text { number } \\
\text { (fig. 1) }\end{array}$} & \multirow[b]{2}{*}{$\begin{array}{l}\text { U.S. Geological } \\
\text { Survey site } \\
\text { identification }\end{array}$} & \multirow[b]{2}{*}{ Site name } & \multirow{2}{*}{$\begin{array}{c}\text { Land- } \\
\text { surface } \\
\text { altitude } \\
\text { (feet above } \\
\text { sea level) }\end{array}$} & \multirow{2}{*}{$\begin{array}{l}\text { Height of } \\
\text { measure- } \\
\text { ment } \\
\text { point (feet } \\
\text { above land } \\
\text { surface) }\end{array}$} & \multicolumn{7}{|c|}{ Water-level measurement } \\
\hline & & & & & Date & Time & $\begin{array}{l}\text { Depth to } \\
\text { water (feet } \\
\text { below land } \\
\text { surface) }\end{array}$ & $\begin{array}{c}\text { Altitude of } \\
\text { water surface } \\
\text { (feet above } \\
\text { sea level) }\end{array}$ & Method & $\begin{array}{l}\text { Site } \\
\text { status }\end{array}$ & $\begin{array}{l}\text { Data } \\
\text { source }\end{array}$ \\
\hline \multirow[t]{17}{*}{ AM-5 } & 362529116171100 & Devils Hole Well & $2,404.1$ & 0.9 & $01-16-2003$ & 0810 & 48.16 & $2,355.9$ & $\mathrm{~S}$ & - & EMP \\
\hline & & & & & $01-23-2003$ & 0930 & 48.13 & $2,356.0$ & $\mathrm{~T}$ & - & USFWS \\
\hline & & & & & $02-24-2003$ & 1332 & 47.99 & $2,356.1$ & $\mathrm{~S}$ & - & EMP \\
\hline & & & & & 03-06-2003 & 1312 & 48.12 & $2,356.0$ & $\mathrm{~S}$ & - & EMP \\
\hline & & & & & 04-03-2003 & 1301 & 48.16 & $2,355.9$ & $\mathrm{~S}$ & - & EMP \\
\hline & & & & & $05-15-2003$ & 1100 & 48.21 & $2,355.9$ & $\mathrm{~T}$ & - & USFWS \\
\hline & & & & & $05-22-2003$ & 1108 & 48.10 & $2,356.0$ & $\mathrm{~S}$ & - & EMP \\
\hline & & & & & $06-16-2003$ & 0759 & 48.10 & $2,356.0$ & $\mathrm{~S}$ & - & EMP \\
\hline & & & & & $07-21-2003$ & 1230 & 48.15 & $2,356.0$ & $\mathrm{~T}$ & - & USFWS \\
\hline & & & & & 07-23-2003 & 1029 & 48.19 & $2,355.9$ & $\mathrm{~S}$ & - & EMP \\
\hline & & & & & 08-20-2003 & 1050 & 48.20 & $2,355.9$ & $\mathrm{~S}$ & - & EMP \\
\hline & & & & & 09-15-2003 & 0918 & 48.19 & $2,355.9$ & $\mathrm{~T}$ & - & USFWS \\
\hline & & & & & 09-15-2003 & 1830 & 48.11 & $2,356.0$ & $\mathrm{~S}$ & - & EMP \\
\hline & & & & & $10-15-2003$ & 0908 & 48.17 & $2,355.9$ & $\mathrm{~S}$ & - & EMP \\
\hline & & & & & $11-17-2003$ & 1443 & 48.17 & 2,355.9 & $\mathrm{S}$ & - & EMP \\
\hline & & & & & $12-05-2003$ & 1425 & 48.15 & $2,356.0$ & $\mathrm{~S}$ & - & EMP \\
\hline & & & & & $12-16-2003$ & 1320 & 48.30 & $2,355.8$ & $\mathrm{~T}$ & - & USFWS \\
\hline
\end{tabular}




\begin{tabular}{|c|c|c|c|c|c|c|c|c|c|c|c|}
\hline \multirow[b]{2}{*}{$\begin{array}{c}\text { Site } \\
\text { number } \\
\text { (fig. 1) }\end{array}$} & \multirow[b]{2}{*}{$\begin{array}{l}\text { U.S. Geological } \\
\text { Survey site } \\
\text { identification }\end{array}$} & \multirow[b]{2}{*}{ Site name } & \multirow{2}{*}{$\begin{array}{c}\text { Land- } \\
\text { surface } \\
\text { altitude } \\
\text { (feet above } \\
\text { sea level) }\end{array}$} & \multirow{2}{*}{$\begin{array}{l}\text { Height of } \\
\text { measure- } \\
\text { ment } \\
\text { point (feet } \\
\text { above land } \\
\text { surface) }\end{array}$} & \multicolumn{7}{|c|}{ Water-level measurement } \\
\hline & & & & & Date & Time & $\begin{array}{l}\text { Depth to } \\
\text { water (feet } \\
\text { below land } \\
\text { surface) }\end{array}$ & $\begin{array}{c}\text { Altitude of } \\
\text { water surface } \\
\text { (feet above } \\
\text { sea level) }\end{array}$ & Method & $\begin{array}{c}\text { Site } \\
\text { status }\end{array}$ & $\begin{array}{l}\text { Data } \\
\text { source }\end{array}$ \\
\hline \multirow[t]{16}{*}{ AM-6 } & 362432116165701 & Point of Rocks North Well & $2,318.8$ & 0.0 & 01-16-2003 & 1326 & 21.43 & $2,297.4$ & $\mathrm{~S}$ & - & EMP \\
\hline & & & & & 02-06-2003 & 1308 & 21.44 & $2,297.4$ & $\mathrm{~S}$ & - & EMP \\
\hline & & & & & 03-06-2003 & 1209 & 21.54 & $2,297.3$ & $\mathrm{~S}$ & - & EMP \\
\hline & & & & & 04-03-2003 & 1201 & 21.46 & $2,297.3$ & $\mathrm{~S}$ & - & EMP \\
\hline & & & & & $05-15-2003$ & 1200 & 21.40 & $2,297.4$ & $\mathrm{~T}$ & - & USFWS \\
\hline & & & & & $05-22-2003$ & 1007 & 21.43 & $2,297.4$ & $\mathrm{~S}$ & - & EMP \\
\hline & & & & & $06-12-2003$ & 1815 & 21.58 & $2,297.2$ & $\mathrm{~S}$ & - & EMP \\
\hline & & & & & 07-23-2003 & -- & 21.66 & $2,297.1$ & $\mathrm{~T}$ & - & USFWS \\
\hline & & & & & $07-23-2003$ & 0919 & 21.70 & $2,297.1$ & $\mathrm{~S}$ & - & EMP \\
\hline & & & & & $08-20-2003$ & 1135 & 21.71 & $2,297.1$ & $\mathrm{~S}$ & - & EMP \\
\hline & & & & & 09-15-2003 & 1821 & 21.63 & $2,297.2$ & $\mathrm{~S}$ & - & EMP \\
\hline & & & & & 09-18-2003 & 1400 & 21.58 & $2,297.2$ & $\mathrm{~T}$ & - & USFWS \\
\hline & & & & & $10-15-2003$ & 0956 & 21.63 & $2,297.2$ & $\mathrm{~S}$ & - & EMP \\
\hline & & & & & $11-17-2003$ & 1518 & 21.52 & $2,297.3$ & $\mathrm{~S}$ & - & EMP \\
\hline & & & & & $12-05-2003$ & 1334 & 21.50 & $2,297.3$ & $\mathrm{~S}$ & - & EMP \\
\hline & & & & & $12-16-2003$ & 1442 & 21.46 & $2,297.3$ & $\mathrm{~T}$ & - & USFWS \\
\hline
\end{tabular}


Table 5. Periodic water-level data at monitoring sites in Yucca Mountain region, 2003-Continued

\begin{tabular}{|c|c|c|c|c|c|c|c|c|c|c|c|}
\hline \multirow[b]{2}{*}{$\begin{array}{c}\text { Site } \\
\text { number } \\
\text { (fig. 1) }\end{array}$} & \multirow[b]{2}{*}{$\begin{array}{l}\text { U.S. Geological } \\
\text { Survey site } \\
\text { identification }\end{array}$} & \multirow[b]{2}{*}{ Site name } & \multirow{2}{*}{$\begin{array}{c}\text { Land- } \\
\text { surface } \\
\text { altitude } \\
\text { (feet above } \\
\text { sea level) }\end{array}$} & \multirow{2}{*}{$\begin{array}{l}\text { Height of } \\
\text { measure- } \\
\text { ment } \\
\text { point (feet } \\
\text { above land } \\
\text { surface) }\end{array}$} & \multicolumn{7}{|c|}{ Water-level measurement } \\
\hline & & & & & Date & Time & $\begin{array}{l}\text { Depth to } \\
\text { water (feet } \\
\text { below land } \\
\text { surface) }\end{array}$ & $\begin{array}{c}\text { Altitude of } \\
\text { water surface } \\
\text { (feet above } \\
\text { sea level) }\end{array}$ & Method & $\begin{array}{l}\text { Site } \\
\text { status }\end{array}$ & $\begin{array}{c}\text { Data } \\
\text { source }\end{array}$ \\
\hline \multirow[t]{17}{*}{ AM-7 } & 362417116163600 & Point of Rocks South Well & $2,333.5$ & 0.8 & $01-16-2003$ & 1407 & 7.39 & $2,326.1$ & $\mathrm{~S}$ & - & EMP \\
\hline & & & & & $01-23-2003$ & 1030 & 7.41 & $2,326.1$ & $\mathrm{~T}$ & - & USFWS \\
\hline & & & & & $02-06-2003$ & 1334 & 7.35 & $2,326.2$ & $\mathrm{~S}$ & - & EMP \\
\hline & & & & & 03-06-2003 & 1244 & 8.25 & $2,325.2$ & $\mathrm{~S}$ & - & EMP \\
\hline & & & & & 04-03-2003 & 1229 & 7.29 & $2,326.2$ & $\mathrm{~S}$ & - & EMP \\
\hline & & & & & $05-15-2003$ & 1340 & 7.33 & $2,326.2$ & $\mathrm{~T}$ & - & USFWS \\
\hline & & & & & $05-22-2003$ & 1038 & 7.33 & $2,326.2$ & $\mathrm{~S}$ & - & EMP \\
\hline & & & & & $06-12-2003$ & 1750 & 7.37 & $2,326.1$ & $\mathrm{~S}$ & - & EMP \\
\hline & & & & & $07-23-2003$ & -- & 7.60 & $2,325.9$ & $\mathrm{~T}$ & - & USFWS \\
\hline & & & & & $07-23-2003$ & 0958 & 7.60 & $2,325.9$ & $\mathrm{~S}$ & - & EMP \\
\hline & & & & & $08-20-2003$ & 1209 & 7.63 & $2,325.9$ & $\mathrm{~S}$ & - & EMP \\
\hline & & & & & $09-15-2003$ & 1756 & 7.54 & $2,326.0$ & $\mathrm{~S}$ & - & EMP \\
\hline & & & & & $09-18-2003$ & 1448 & 7.60 & $2,325.9$ & $\mathrm{~T}$ & - & USFWS \\
\hline & & & & & $10-15-2003$ & 1041 & 7.52 & $2,326.0$ & $\mathrm{~S}$ & - & EMP \\
\hline & & & & & $11-17-2003$ & 1550 & 7.44 & $2,326.1$ & $\mathrm{~S}$ & - & EMP \\
\hline & & & & & $12-05-2003$ & 1400 & 7.38 & $2,326.1$ & $\mathrm{~S}$ & - & EMP \\
\hline & & & & & $12-16-2003$ & 1506 & 7.45 & $2,326.0$ & $\mathrm{~T}$ & - & USFWS \\
\hline \multirow[t]{12}{*}{ DV-3 } & 362230116392901 & Travertine Point 1 Well & $2,728.4$ & 2.0 & $01-28-2003$ & 1443 & 602.21 & $2,126.2$ & $\mathrm{~V}$ & - & EMP \\
\hline & & & & & $02-26-2003$ & 1130 & 602.14 & $2,126.3$ & $\mathrm{~V}$ & - & EMP \\
\hline & & & & & $03-12-2003$ & 1219 & 602.19 & $2,126.2$ & V & - & EMP \\
\hline & & & & & $04-23-2003$ & 1319 & 602.23 & $2,126.2$ & V & - & EMP \\
\hline & & & & & $05-21-2003$ & 0946 & 602.24 & $2,126.2$ & $\mathrm{~V}$ & - & EMP \\
\hline & & & & & $06-12-2003$ & 1348 & 602.20 & $2,126.2$ & V & - & EMP \\
\hline & & & & & $07-24-2003$ & 0742 & 602.26 & $2,126.1$ & V & - & EMP \\
\hline & & & & & $08-19-2003$ & 1417 & 602.26 & $2,126.1$ & $\mathrm{~V}$ & - & EMP \\
\hline & & & & & 09-16-2003 & 1551 & 602.25 & $2,126.2$ & $\mathrm{~V}$ & - & EMP \\
\hline & & & & & $10-15-2003$ & 1307 & 602.29 & $2,126.1$ & V & - & EMP \\
\hline & & & & & $11-18-2003$ & 1108 & 602.46 & $2,125.9$ & V & - & EMP \\
\hline & & & & & $12-09-2003$ & 1143 & 602.45 & $2,126.0$ & $\mathrm{~V}$ & - & EMP \\
\hline
\end{tabular}




\begin{tabular}{|c|c|c|c|c|c|c|c|c|c|c|c|c|}
\hline \multirow{2}{*}{ Day } & \multicolumn{12}{|c|}{ Water level, in feet below land surface } \\
\hline & Jan & Feb & Mar & Apr & May & Jun & Jul & Aug & Sep & Oct & Nov & Dec \\
\hline 1 & 709.86 & 709.27 & 709.70 & 709.11 & 709.66 & 709.54 & 709.55 & 709.60 & 709.50 & 709.55 & 709.59 & 709.47 \\
\hline 2 & 709.85 & 709.48 & 709.84 & 709.20 & 709.52 & 709.47 & 709.54 & 709.52 & 709.58 & 709.36 & 709.51 & 709.61 \\
\hline 3 & 709.76 & 709.73 & 709.53 & 709.55 & 709.48 & 709.46 & 709.54 & 709.49 & 709.58 & 709.37 & 709.51 & 709.47 \\
\hline 4 & 709.71 & 709.55 & 709.42 & 709.46 & 709.59 & 709.45 & 709.52 & 709.48 & 709.59 & 709.52 & 709.64 & 709.47 \\
\hline 5 & 709.65 & 709.59 & 709.66 & 709.55 & 709.58 & 709.54 & 709.47 & 709.47 & 709.56 & 709.55 & 709.63 & 709.43 \\
\hline 6 & 709.74 & 709.66 & 709.71 & 709.67 & 709.45 & 709.54 & 709.41 & 709.49 & 709.49 & 709.51 & 709.65 & 709.28 \\
\hline 7 & 709.71 & 709.66 & 709.64 & 709.83 & 709.45 & 709.50 & 709.47 & 709.52 & 709.41 & 709.44 & 709.60 & 709.20 \\
\hline 8 & 709.54 & 709.56 & 709.77 & 709.80 & 709.45 & 709.46 & 709.60 & 709.53 & 709.33 & 709.50 & 709.58 & 709.51 \\
\hline 9 & 709.51 & 709.69 & 709.79 & 709.55 & 709.62 & 709.47 & 709.64 & 709.56 & 709.34 & 709.40 & 709.50 & 709.63 \\
\hline 10 & 709.56 & 709.68 & 709.65 & 709.44 & 709.76 & 709.54 & 709.61 & 709.58 & 709.59 & 709.42 & 709.54 & 709.38 \\
\hline 11 & 709.69 & 709.61 & 709.51 & 709.47 & 709.70 & 709.55 & 709.59 & 709.50 & 709.74 & 709.67 & 709.63 & 709.33 \\
\hline 12 & 709.81 & 709.51 & 709.57 & 709.43 & 709.62 & 709.52 & 709.56 & 709.44 & 709.53 & 709.66 & 709.47 & 709.60 \\
\hline 13 & 709.80 & 709.39 & 709.58 & 709.49 & 709.59 & 709.60 & 709.53 & 709.54 & 709.53 & 709.70 & 709.55 & 709.64 \\
\hline 14 & 709.63 & 709.50 & 709.47 & 709.45 & 709.46 & 709.65 & 709.50 & 709.60 & 709.59 & 709.56 & 709.55 & 709.39 \\
\hline 15 & 709.75 & 709.66 & 709.33 & 709.60 & 709.52 & 709.59 & 709.49 & 709.61 & 709.46 & 709.50 & 709.43 & 709.75 \\
\hline 16 & 709.78 & 709.63 & 709.34 & 709.64 & 709.58 & 709.56 & 709.55 & 709.61 & 709.34 & 709.67 & 709.40 & 709.87 \\
\hline 17 & 709.65 & 709.67 & 709.46 & 709.44 & 709.50 & 709.53 & 709.60 & 709.48 & 709.43 & 709.69 & 709.53 & 709.67 \\
\hline 18 & 709.60 & 709.67 & 709.74 & 709.52 & 709.57 & 709.43 & 709.57 & 709.44 & 709.64 & 709.60 & 709.77 & 709.56 \\
\hline 19 & 709.60 & 709.52 & 709.79 & 709.72 & 709.74 & 709.35 & 709.63 & 709.51 & 709.54 & 709.57 & 709.60 & 709.44 \\
\hline 20 & 709.55 & 709.56 & 709.72 & 709.60 & 709.67 & 709.41 & 709.57 & 709.62 & 709.50 & 709.61 & 709.33 & 709.27 \\
\hline 21 & 709.58 & 709.70 & 709.82 & 709.31 & 709.59 & 709.49 & 709.50 & 709.57 & 709.52 & 709.59 & 709.13 & 709.39 \\
\hline 22 & 709.73 & 709.51 & 709.75 & 709.36 & 709.53 & 709.48 & 709.47 & 709.47 & 709.52 & 709.50 & 709.55 & 709.62 \\
\hline 23 & 709.65 & 709.40 & 709.53 & 709.57 & 709.48 & 709.39 & 709.53 & 709.50 & 709.49 & 709.43 & 709.79 & 709.41 \\
\hline 24 & 709.59 & 709.35 & 709.55 & 709.54 & 709.38 & 709.67 & 709.47 & 709.59 & 709.53 & 709.53 & 709.46 & 709.29 \\
\hline 25 & 709.69 & 709.41 & 709.81 & 709.49 & 709.41 & 709.88 & 709.52 & 709.55 & 709.58 & 709.71 & 709.25 & 709.07 \\
\hline 26 & 709.75 & 709.51 & 709.58 & 709.54 & 709.61 & 709.81 & 709.64 & 709.53 & 709.53 & 709.74 & 709.48 & 709.40 \\
\hline 27 & 709.51 & 709.55 & 709.60 & 709.50 & 709.70 & 709.61 & 709.58 & 709.52 & 709.50 & 709.53 & 709.94 & 709.82 \\
\hline 28 & 709.53 & 709.67 & 709.87 & 709.50 & 709.61 & 709.50 & 709.50 & 709.50 & 709.50 & 709.26 & 709.77 & 709.80 \\
\hline 29 & 709.69 & --- & 709.98 & 709.56 & 709.50 & 709.51 & 709.52 & 709.49 & 709.48 & 708.97 & 709.48 & 709.39 \\
\hline 30 & 709.71 & --- & 709.80 & 709.63 & 709.45 & 709.56 & 709.58 & 709.54 & 709.58 & 709.01 & 709.43 & 709.36 \\
\hline 31 & 709.64 & --- & 709.43 & --- & 709.51 & --- & 709.64 & 709.47 & --- & 709.36 & --- & 709.38 \\
\hline MEAN & 709.67 & 709.56 & 709.64 & 709.52 & 709.56 & 709.54 & 709.54 & 709.53 & 709.52 & 709.50 & 709.54 & 709.48 \\
\hline MAX & 709.86 & 709.73 & 709.98 & 709.83 & 709.76 & 709.88 & 709.64 & 709.62 & 709.74 & 709.74 & 709.94 & 709.87 \\
\hline MIN & 709.51 & 709.27 & 709.33 & 709.11 & 709.38 & 709.35 & 709.41 & 709.44 & 709.33 & 708.97 & 709.13 & 709.07 \\
\hline$(2003 \mathrm{ar}$ & immary & Mear & 9.55 & Maxim & 1709.98 & Minimu & 708.97) & & & & & \\
\hline
\end{tabular}


Table 7. Daily average water levels in well AD-6 for calendar year 2003

[---, data not available]

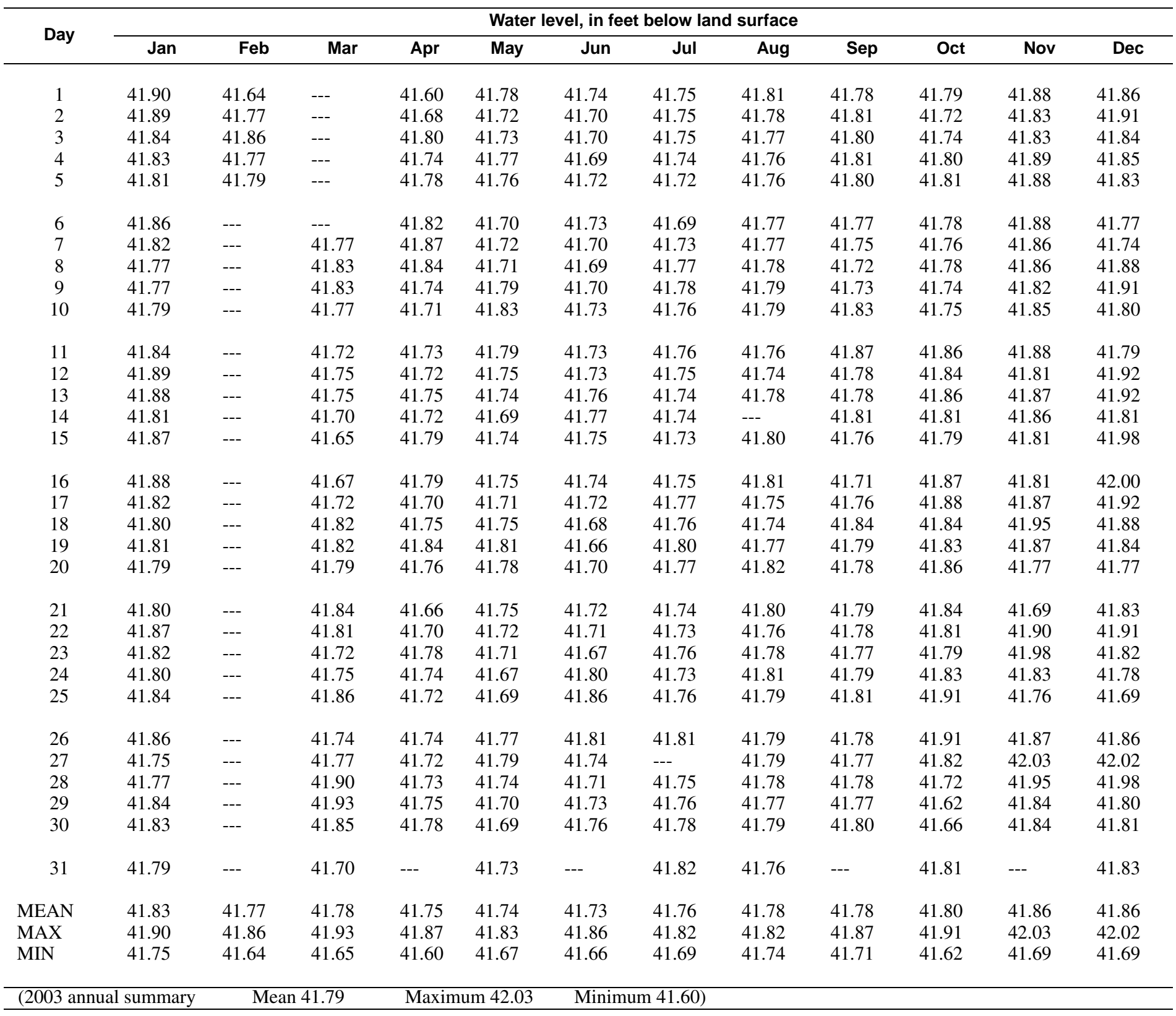


Table 8. Ground-water-discharge data at monitoring sites in Yucca Mountain region, 2003

Site number: Alphanumeric identifier used to identify sites on maps and tables. First part represents hydrographic area in which site is located. Hydrographic areas: AD or AM, Amargosa Desert; DV, Death Valley. Second part is sequential numbering representing relative location of site within hydrographic area or Ash Meadows spring-discharge area; numbering order generally is north to south, then west to east.

U.S. Geological Survey site identification: Unique identification number for site as stored in files and data bases of U.S. Geological Survey (USGS).

Discharge: Reported to two significant figures. Discharge measured at site AM-2 represents a combination of flow directly through slotted casing at land surface and leakage from the casing's annular space.

Method: Method used to measure discharge. C, current meter; V, volumetric; Z, discharge represents monthly mean discharge on basis of continually recorded stage.

Data source: EMP, Environmental-Monitoring Program (USGS); NPS, National Park Service; USFWS, U.S. Fish and Wildlife Service.

[--, measurement time not available or not applicable]

\begin{tabular}{|c|c|c|c|c|c|c|c|}
\hline \multirow{2}{*}{$\begin{array}{c}\text { Site } \\
\text { number } \\
\text { (fig.1) }\end{array}$} & \multirow{2}{*}{$\begin{array}{l}\text { U.S. Geological } \\
\text { Survey site } \\
\text { identification }\end{array}$} & \multirow[b]{2}{*}{ Site name } & \multicolumn{5}{|c|}{ Discharge measurement } \\
\hline & & & Date & Time & $\begin{array}{l}\text { Discharge } \\
\text { (gallons per } \\
\text { minute) }\end{array}$ & Method & $\begin{array}{l}\text { Data } \\
\text { source }\end{array}$ \\
\hline \multirow[t]{4}{*}{ AM-1a } & 362924116203001 & Fairbanks Spring & $03-27-2003$ & 1157 & 1,600 & $\mathrm{C}$ & EMP \\
\hline & & & 06-24-2003 & 0738 & 1,600 & $\mathrm{C}$ & EMP \\
\hline & & & 09-05-2003 & 1331 & 1,600 & $\mathrm{C}$ & EMP \\
\hline & & & $12-18-2003$ & 1039 & 1,600 & $\mathrm{C}$ & EMP \\
\hline \multirow[t]{12}{*}{ AM-2 } & 362755116190401 & Five Springs Well & 01-16-2003 & 1201 & 38 & $\mathrm{~V}$ & EMP \\
\hline & & & 02-06-2003 & 1501 & 37 & $\mathrm{~V}$ & EMP \\
\hline & & & 03-06-2003 & 1424 & 38 & $\mathrm{~V}$ & EMP \\
\hline & & & 04-03-2003 & 1411 & 37 & $\mathrm{~V}$ & EMP \\
\hline & & & $05-22-2003$ & 0836 & 35 & $\mathrm{~V}$ & EMP \\
\hline & & & 06-13-2003 & 1206 & 33 & $\mathrm{~V}$ & EMP \\
\hline & & & $07-23-2003$ & 0733 & 35 & $\mathrm{~V}$ & EMP \\
\hline & & & 08-19-2003 & 1644 & 35 & $\mathrm{~V}$ & EMP \\
\hline & & & 09-29-2003 & 1158 & 35 & $\mathrm{~V}$ & EMP \\
\hline & & & $10-27-2003$ & 1536 & 38 & $\mathrm{~V}$ & EMP \\
\hline & & & $11-17-2003$ & 1249 & 38 & $\mathrm{~V}$ & EMP \\
\hline & & & $12-05-2003$ & 1132 & 36 & $\mathrm{~V}$ & EMP \\
\hline \multirow[t]{9}{*}{ AM-5a } & 362502116192301 & Crystal Pool & $01-22-2003$ & 1315 & 2,900 & $\mathrm{C}$ & USFWS \\
\hline & & & 03-14-2003 & 1414 & 2,600 & $\mathrm{C}$ & EMP \\
\hline & & & $05-15-2003$ & 0930 & 2,700 & $\mathrm{C}$ & USFWS \\
\hline & & & $06-26-2003$ & 1448 & 2,800 & $\mathrm{C}$ & EMP \\
\hline & & & $07-23-2003$ & 0700 & 2,600 & $\mathrm{C}$ & USFWS \\
\hline & & & 08-29-2003 & 1124 & 2,600 & $\mathrm{C}$ & EMP \\
\hline & & & 09-24-2003 & 1028 & 2,800 & $\mathrm{C}$ & USFWS \\
\hline & & & $10-22-2003$ & 1340 & 2,700 & $\mathrm{C}$ & USFWS \\
\hline & & & $12-12-2003$ & 1511 & 3,000 & $\mathrm{C}$ & EMP \\
\hline \multirow[t]{9}{*}{ AM-8 } & 362230116162001 & Big Spring & $01-23-2003$ & 1500 & 990 & $\mathrm{C}$ & USFWS \\
\hline & & & 03-14-2003 & 1656 & 1,000 & $\mathrm{C}$ & EMP \\
\hline & & & $05-20-2003$ & 1000 & 1,100 & $\mathrm{C}$ & USFWS \\
\hline & & & 06-24-2003 & 1007 & 990 & $\mathrm{C}$ & EMP \\
\hline & & & $07-23-2003$ & 1347 & 980 & $\mathrm{C}$ & USFWS \\
\hline & & & 08-29-2003 & 1024 & 1,100 & $\mathrm{C}$ & EMP \\
\hline & & & $09-25-2003$ & 0830 & 1,000 & $\mathrm{C}$ & USFWS \\
\hline & & & $12-12-2003$ & 1225 & 1,100 & $\mathrm{C}$ & EMP \\
\hline & & & $12-18-2003$ & 0916 & 1,000 & $\mathrm{C}$ & USFWS \\
\hline
\end{tabular}


Table 8. Ground-water-discharge data at monitoring sites in Yucca Mountain region, 2003—Continued

\begin{tabular}{|c|c|c|c|c|c|c|c|}
\hline \multirow[b]{2}{*}{$\begin{array}{c}\text { Site } \\
\text { number } \\
\text { (fig.1) }\end{array}$} & \multirow[b]{2}{*}{$\begin{array}{l}\text { U.S. Geological } \\
\text { Survey site } \\
\text { identification }\end{array}$} & \multirow[b]{2}{*}{ Site name } & \multicolumn{5}{|c|}{ Discharge measurement } \\
\hline & & & Date & Time & $\begin{array}{l}\text { Discharge } \\
\text { (gallons per } \\
\text { minute) }\end{array}$ & Method & $\begin{array}{l}\text { Data } \\
\text { source }\end{array}$ \\
\hline \multirow[t]{16}{*}{$\overline{D V}-1$} & 362728116501101 & Texas Spring & $01-15-2003$ & -- & 200 & $\mathrm{Z}$ & NPS \\
\hline & & & $02-15-2003$ & -- & 200 & $\mathrm{Z}$ & NPS \\
\hline & & & $03-15-2003$ & -- & 200 & $\mathrm{Z}$ & NPS \\
\hline & & & 03-19-2003 & 1342 & 190 & $\mathrm{C}$ & EMP \\
\hline & & & $04-15-2003$ & -- & 200 & Z & NPS \\
\hline & & & $05-15-2003$ & -- & 200 & $\mathrm{Z}$ & NPS \\
\hline & & & $06-15-2003$ & -- & 190 & $\mathrm{Z}$ & NPS \\
\hline & & & $06-17-2003$ & 1036 & 180 & $\mathrm{C}$ & EMP \\
\hline & & & $07-15-2003$ & -- & 200 & $\mathrm{Z}$ & NPS \\
\hline & & & $08-15-2003$ & -- & 190 & $\mathrm{Z}$ & NPS \\
\hline & & & 09-04-2003 & 1416 & 200 & $\mathrm{C}$ & EMP \\
\hline & & & $09-15-2003$ & -- & 200 & $\mathrm{Z}$ & NPS \\
\hline & & & $10-15-2003$ & -- & 200 & $\mathrm{Z}$ & NPS \\
\hline & & & $11-15-2003$ & -- & 200 & $\mathrm{Z}$ & NPS \\
\hline & & & $12-15-2003$ & -- & 200 & Z & NPS \\
\hline & & & $12-18-2003$ & 1322 & 190 & $\mathrm{C}$ & EMP \\
\hline \multirow[t]{4}{*}{ DV-2 } & 362252116425301 & Navel Spring & 03-19-2003 & 1518 & 0.87 & $\mathrm{~V}$ & EMP \\
\hline & & & $06-17-2003$ & 1204 & 0.82 & $\mathrm{~V}$ & EMP \\
\hline & & & 09-04-2003 & 1549 & 0.84 & $\mathrm{~V}$ & EMP \\
\hline & & & $12-11-2003$ & 1423 & 0.83 & $\mathrm{~V}$ & EMP \\
\hline
\end{tabular}


Table 9. Estimated annual ground-water withdrawals from wells in Yucca Mountain region, 1959-2003

\begin{tabular}{|c|c|c|c|c|c|c|}
\hline \multirow[b]{3}{*}{ Year } & \multicolumn{3}{|c|}{ Alkali Flat-Furnace Creek Ranch ground-water subbasin (fig. 1) } & \multicolumn{3}{|c|}{ Ash Meadows ground-water subbasin (fig. 1) } \\
\hline & \multicolumn{3}{|c|}{ (millions of gallons) } & \multicolumn{3}{|c|}{ (millions of gallons) } \\
\hline & Amargosa Desert $^{1}$ & Crater Flat $^{2}$ & Jackass Flats $^{2}$ & $\begin{array}{l}\text { Amargosa } \\
\text { Desert } \\
\text { (excluding Ash } \\
\text { Meadows }^{1} \\
\text { area) }^{1}\end{array}$ & $\begin{array}{c}\text { Amargosa Desert } \\
(\text { Ash Meadows area })^{1}\end{array}$ & Mercury Valley ${ }^{2}$ \\
\hline 1959 & -- & -- & ${ }^{3} 10.3$ & -- & -- & -- \\
\hline 1960 & -- & -- & ${ }^{3} 14.8$ & -- & -- & -- \\
\hline 1961 & -- & -- & 30.0 & -- & -- & -- \\
\hline 1962 & -- & -- & ${ }^{3} 60.6$ & -- & -- & 4.2 \\
\hline 1963 & -- & -- & ${ }^{3} 182.5$ & -- & -- & 2.7 \\
\hline 1964 & -- & -- & ${ }^{3} 182.5$ & -- & -- & ${ }^{3} 32.4$ \\
\hline 1965 & -- & -- & ${ }^{3} 182.5$ & -- & -- & 25.4 \\
\hline 1966 & 1,370 & -- & ${ }^{3} 182.5$ & -- & -- & 47.3 \\
\hline 1967 & 3,025 & -- & ${ }^{3} 182.5$ & -- & -- & 56.1 \\
\hline 1968 & 2,947 & -- & -- & -- & -- & 52.7 \\
\hline 1969 & -- & -- & -- & -- & 650 & 78.1 \\
\hline 1970 & -- & -- & -- & -- & 2,200 & 69.4 \\
\hline 1971 & -- & -- & -- & -- & 2,200 & 96.1 \\
\hline 1972 & -- & -- & -- & -- & 2,000 & ${ }^{3} 85.4$ \\
\hline 1973 & 2,321 & -- & -- & -- & 1,400 & ${ }^{3} 70.1$ \\
\hline 1974 & -- & -- & -- & -- & 1,300 & ${ }^{3} 77.9$ \\
\hline 1975 & -- & -- & -- & -- & 1,200 & ${ }^{3} 76.6$ \\
\hline 1976 & -- & -- & -- & -- & 1,200 & ${ }^{3} 64.9$ \\
\hline 1977 & -- & -- & -- & -- & 620 & ${ }^{3} 57.7$ \\
\hline 1978 & -- & -- & ${ }^{3} 5.9$ & -- & 10 & ${ }^{3} 60.0$ \\
\hline 1979 & -- & -- & ${ }^{3} 12.4$ & -- & 85 & ${ }^{3} 51.5$ \\
\hline 1980 & -- & -- & ${ }^{3} 24.4$ & -- & 10 & ${ }^{3} 59.3$ \\
\hline 1981 & -- & -- & ${ }^{3} 48.6$ & -- & 30 & ${ }^{3} 65.5$ \\
\hline
\end{tabular}


Table 9. Estimated annual ground-water withdrawals from wells in Yucca Mountain region, 1959-2003—Continued

\begin{tabular}{|c|c|c|c|c|c|c|}
\hline \multirow[b]{3}{*}{ Year } & \multicolumn{3}{|c|}{ Alkali Flat-Furnace Creek Ranch ground-water subbasin (fig. 1) } & \multicolumn{3}{|c|}{ Ash Meadows ground-water subbasin (fig. 1) } \\
\hline & \multicolumn{3}{|c|}{ (millions of gallons) } & \multicolumn{3}{|c|}{ (millions of gallons) } \\
\hline & Amargosa Desert $^{1}$ & Crater Flat $^{2}$ & Jackass Flats $^{2}$ & $\begin{array}{l}\text { Amargosa } \\
\text { Desert } \\
\text { (excluding Ash } \\
\text { Meadows } \\
\text { area) }^{1}\end{array}$ & $\begin{array}{c}\text { Amargosa Desert } \\
(\text { Ash Meadows area) })^{1}\end{array}$ & Mercury Valley ${ }^{2}$ \\
\hline 1982 & -- & -- & ${ }^{3} 41.8$ & -- & $<1$ & 373.0 \\
\hline 1983 & -- & -- & 70.6 & -- & -- & 56.8 \\
\hline 1984 & -- & -- & 65.9 & -- & -- & 82.1 \\
\hline 1985 & 3,155 & -- & 53.6 & -- & -- & 41.6 \\
\hline 1986 & 2,362 & -- & 46.0 & -- & -- & 34.9 \\
\hline 1987 & 1,877 & -- & 52.9 & -- & -- & 34.7 \\
\hline 1988 & 1,339 & -- & 46.0 & -- & -- & 53.1 \\
\hline 1989 & 1,278 & 12.8 & 50.6 & -- & -- & 114.4 \\
\hline 1990 & 2,544 & 43.4 & 51.7 & -- & -- & 126.0 \\
\hline 1991 & 1,995 & 13.9 & 51.2 & -- & -- & 109.9 \\
\hline 1992 & 2,644 & 9.5 & 38.9 & 16 & -- & 139.4 \\
\hline 1993 & 3,666 & 4.9 & 66.8 & 16 & -- & 110.2 \\
\hline 1994 & 4,104 & 14.8 & 90.2 & -- & -- & 76.9 \\
\hline 1995 & 4,899 & 10.0 & 90.6 & -- & -- & 24.1 \\
\hline 1996 & 4,422 & ${ }^{3} 32.8$ & 127.4 & 4 & 10 & 17.7 \\
\hline 1997 & 4,509 & ${ }^{3} 108.0$ & 112.2 & 19 & 2 & 11.4 \\
\hline 1998 & 4,989 & ${ }^{3} 54.3$ & 48.8 & 19 & 3 & 1.0 \\
\hline 1999 & 4,598 & 399.1 & 33.3 & 20 & 3 & ${ }^{3} 1.5$ \\
\hline 2000 & 4,054 & ${ }^{3} 41.1$ & 29.2 & 21 & 6 & 0.6 \\
\hline 2001 & 3,907 & ${ }^{3} 15.4$ & 36.2 & 19 & 6 & 37.6 \\
\hline 2002 & 4,025 & ${ }^{3} 16.2$ & 17.7 & 19 & 3 & 53.0 \\
\hline 2003 & 4,405 & 14.4 & 13.5 & 19 & 3 & 50.9 \\
\hline
\end{tabular}

${ }^{1}$ Data recompiled from ground-water pumpage inventory for entire Amargosa Desert. Conversion from acre-feet to millions of gallons (325.851 gallons per acre-foot) is rounded to nearest 1 million gallons.

${ }^{2}$ Data reported, estimated, or recompiled from flowmeter readings and listed to nearest 0.1 million gallons. See text section "Ground-Water Withdrawals" for discussion of data sources.

${ }^{3}$ Estimated ground-water withdrawal revised from that in previous reports on selected ground-water data for the Yucca Mountain region. Revisions are on the basis of more-recent information or further reviews by data sources. 
Table 10. Minimum, maximum, and median water-level altitudes, and average deviation of measurements, at selected wells in Jackass Flats for the baseline period 1992-93 and for calendar years 1994 through 2003

Calendar years: Years for which measurements were used to calculate summary statistics. Italics indicate 1992-93 baseline period.

Number: Number of water-level measurements for year(s) specified. For JF-2 (1992-93), JF-2a (1992-97), and JF-3, value represents number of daily average water levels.

Water level: Based on periodic water-level measurements for JF-1, JF-2 (after 1993), JF-2a (after 1997), J-13, J-11, and J-12. Based on daily average water levels for JF-2 (1992-93), JF-2a (1992-97), and JF-3.

Minimum: Minimum water-level altitude or minimum daily average water-level altitude for year(s) specified.

Maximum: Maximum water-level altitude or maximum daily average water-level altitude for year(s) specified.

Median: Statistically representative water-level altitude calculated from periodic measurements or daily average water levels for year(s) specified.

Average deviation: Calculated dispersion of measurements about median water-level altitude. Average deviation is equal to sum of absolute differences between measured water levels and median, divided by number of measurements.

Change in median: Differences between median water level for calendar years 1994 through 2003 compared with the 1992-93 baseline period. Minus sign indicates that median water-level altitude was lower for the specified year than for the baseline period.

[Excludes water-level altitudes that may reflect short-term conditions at a site. Abbreviation and symbol: N/A, not applicable (data field is not related to referenced data set); --, transducer installed in site JF-2 prevented periodic measurement for most of 2002]

\begin{tabular}{|c|c|c|c|c|c|c|c|}
\hline \multirow{2}{*}{$\begin{array}{c}\text { Site } \\
\text { number } \\
\text { (fig. 1) }\end{array}$} & \multirow{2}{*}{$\begin{array}{c}\text { Calendar } \\
\text { year(s) }\end{array}$} & \multirow{2}{*}{ Number } & \multicolumn{3}{|c|}{ Water level (feet above sea level) } & \multirow{2}{*}{$\begin{array}{c}\text { Average } \\
\text { deviation } \\
\text { (feet) }\end{array}$} & \multirow{2}{*}{$\begin{array}{c}\text { Change in } \\
\text { median } \\
\text { (feet) }\end{array}$} \\
\hline & & & Minimum & Maximum & Median & & \\
\hline \multirow[t]{11}{*}{ JF-1 } & ${ }^{a} 1992-93$ & $a_{20}$ & $a_{2,391.9}$ & $a_{2,392.7}$ & $2,392.5$ & ${ }^{a} 0.1$ & N/A \\
\hline & 2003 & 16 & $2,393.0$ & $2,393.6$ & $2,393.3$ & 0.1 & 0.8 \\
\hline & 2002 & 16 & $2,393.0$ & $2,393.4$ & $2,393.2$ & 0.1 & 0.7 \\
\hline & 2001 & 18 & $2,392.8$ & $2,393.3$ & $2,393.0$ & 0.1 & 0.5 \\
\hline & 2000 & 14 & $2,392.8$ & $2,393.4$ & $2,392.8$ & 0.1 & 0.3 \\
\hline & 1999 & 12 & $2,392.3$ & $2,393.0$ & $2,392.7$ & 0.1 & 0.2 \\
\hline & 1998 & 22 & $2,392.3$ & $2,392.8$ & $2,392.5$ & 0.1 & 0.0 \\
\hline & 1997 & 10 & $2,392.1$ & $2,392.6$ & $2,392.4$ & 0.1 & -0.1 \\
\hline & 1996 & 8 & $2,392.0$ & $2,392.6$ & $2,392.3$ & 0.2 & -0.2 \\
\hline & 1995 & 7 & $2,392.3$ & $2,392.8$ & $2,392.5$ & 0.2 & 0.0 \\
\hline & 1994 & 12 & $2,392.1$ & $2,392.6$ & $2,392.3$ & 0.1 & -0.2 \\
\hline \multirow[t]{11}{*}{ JF-2 } & ${ }^{a} 1992-93$ & $a_{718}$ & $a_{2,391.7}$ & $a_{2,392.8}$ & $2,392.1$ & ${ }^{a} 0.1$ & N/A \\
\hline & 2003 & 10 & $2,392.6$ & $2,392.9$ & $2,392.6$ & 0.1 & 0.5 \\
\hline & 2002 & 1 & -- & -- & -- & -- & -- \\
\hline & 2001 & 18 & $2,392.4$ & $2,393.2$ & $2,392.8$ & 0.2 & 0.7 \\
\hline & 2000 & 14 & $2,392.3$ & $2,393.2$ & $2,392.7$ & 0.2 & 0.6 \\
\hline & 1999 & 13 & $2,392.0$ & $2,392.7$ & $2,392.5$ & 0.1 & 0.4 \\
\hline & 1998 & 21 & $2,391.8$ & $2,392.6$ & $2,392.1$ & 0.1 & 0.0 \\
\hline & 1997 & 11 & $2,391.8$ & $2,392.4$ & $2,392.0$ & 0.1 & -0.1 \\
\hline & 1996 & 7 & $2,391.6$ & $2,392.3$ & $2,392.1$ & 0.2 & 0.0 \\
\hline & 1995 & 9 & $2,392.2$ & $2,392.5$ & $2,392.4$ & 0.1 & 0.3 \\
\hline & 1994 & 9 & $2,392.0$ & $2,392.6$ & $2,392.2$ & 0.1 & 0.1 \\
\hline \multirow[t]{11}{*}{$J F-2 a$} & ${ }^{a} 1992-93$ & $a_{707}$ & $a_{2,466.9}$ & $a_{2,469.2}$ & $a_{2,468.7}$ & ${ }^{a} 0.3$ & N/A \\
\hline & 2003 & 14 & $2,471.0$ & $2,473.2$ & $2,471.5$ & 0.7 & 2.8 \\
\hline & 2002 & 16 & $2,470.5$ & $2,471.3$ & $2,471.0$ & 0.2 & $a_{2.3}$ \\
\hline & 2001 & 18 & $2,470.8$ & $2,471.2$ & $2,471.0$ & 0.1 & $a_{2.3}$ \\
\hline & 2000 & 14 & $2,470.1$ & $2,471.1$ & $2,470.8$ & 0.3 & $a_{2.1}$ \\
\hline & 1999 & 13 & $2,469.8$ & $2,470.4$ & $2,470.2$ & 0.1 & ${ }^{a} 1.5$ \\
\hline & 1998 & 20 & $2,469.8$ & $2,470.4$ & $2,470.0$ & 0.1 & ${ }^{a} 1.3$ \\
\hline & 1997 & 267 & $2,468.8$ & $2,470.0$ & $2,469.5$ & 0.1 & ${ }^{a} 0.8$ \\
\hline & 1996 & 214 & $2,468.6$ & $2,469.6$ & $2,469.3$ & 0.1 & ${ }^{a} 0.6$ \\
\hline & 1995 & 357 & $2,468.7$ & $2,469.3$ & $2,469.1$ & 0.1 & ${ }^{a} 0.4$ \\
\hline & 1994 & 356 & $2,468.4$ & $2,469.4$ & $2,469.0$ & 0.1 & ${ }^{a} 0.3$ \\
\hline
\end{tabular}


Table 10. Minimum, maximum, and median water-level altitudes, and average deviation of measurements, at selected wells in Jackass Flats for the baseline period 1992-93 and for calendar years 1994 through 2003-Continued

\begin{tabular}{|c|c|c|c|c|c|c|c|}
\hline \multirow{2}{*}{$\begin{array}{c}\text { Site } \\
\text { number } \\
\text { (fig. 1) }\end{array}$} & \multirow{2}{*}{$\begin{array}{c}\text { Calendar } \\
\text { year(s) }\end{array}$} & \multirow{2}{*}{ Number } & \multicolumn{3}{|c|}{ Water level (feet above sea level) } & \multirow{2}{*}{$\begin{array}{c}\text { Average } \\
\text { deviation } \\
\text { (feet) }\end{array}$} & \multirow{2}{*}{$\begin{array}{c}\text { Change in } \\
\text { median } \\
\text { (feet) }\end{array}$} \\
\hline & & & Minimum & Maximum & Median & & \\
\hline \multirow[t]{11}{*}{$\mathrm{J}-13$} & $a_{1992-93}$ & $a_{37}$ & $a_{2,389.6}$ & $2,390.7$ & $a_{2,389.9}$ & 0.1 & N/A \\
\hline & 2003 & 19 & $2,390.2$ & $2,390.9$ & $2,390.6$ & 0.2 & 0.7 \\
\hline & 2002 & 15 & $2,390.0$ & $2,390.8$ & $2,390.4$ & 0.1 & ${ }^{a} 0.5$ \\
\hline & 2001 & 17 & $2,390.1$ & $2,390.9$ & $2,390.4$ & 0.2 & ${ }^{a} 0.5$ \\
\hline & 2000 & 13 & $2,390.0$ & $2,391.0$ & $2,390.2$ & 0.2 & ${ }^{a} 0.3$ \\
\hline & 1999 & 13 & $2,389.6$ & $2,390.2$ & $2,390.0$ & 0.1 & ${ }^{a} 0.1$ \\
\hline & 1998 & 20 & $2,389.4$ & $2,390.2$ & $2,389.8$ & 0.1 & $a_{-0.1}$ \\
\hline & 1997 & 11 & $2,389.5$ & $2,389.9$ & $2,389.6$ & 0.1 & $a_{-0.3}$ \\
\hline & 1996 & 8 & $2,389.2$ & $2,389.9$ & $2,389.6$ & 0.1 & $a_{-0.3}$ \\
\hline & 1995 & 11 & $2,389.6$ & $2,390.4$ & $2,389.8$ & 0.1 & $a_{-0.1}$ \\
\hline & 1994 & 23 & $2,389.4$ & $2,390.0$ & $2,389.7$ & 0.1 & $a_{-0.2}$ \\
\hline \multirow[t]{11}{*}{$\mathrm{J}-11$} & ${ }^{a_{1992-93}}$ & $a_{20}$ & $2,401.9$ & $a_{2,402.7}$ & $2,402.2$ & 0.1 & N/A \\
\hline & 2003 & 17 & $2,402.2$ & $2,402.8$ & $2,402.6$ & 0.1 & 0.4 \\
\hline & 2002 & 16 & $2,402.1$ & $2,402.7$ & $2,402.5$ & 0.1 & 0.3 \\
\hline & 2001 & 18 & $2,402.3$ & $2,403.0$ & $2,402.6$ & 0.2 & 0.4 \\
\hline & 2000 & 14 & $2,402.3$ & $2,403.2$ & $a_{2,402.4}$ & 0.1 & ${ }^{a} 0.2$ \\
\hline & 1999 & 14 & $2,402.2$ & $2,402.8$ & $2,402.4$ & 0.1 & 0.2 \\
\hline & 1998 & 20 & $2,402.2$ & $2,402.9$ & $2,402.6$ & 0.2 & 0.4 \\
\hline & 1997 & 10 & $2,402.2$ & $2,402.8$ & $2,402.6$ & 0.2 & 0.4 \\
\hline & 1996 & 8 & $2,402.2$ & $2,402.6$ & $2,402.4$ & 0.1 & 0.2 \\
\hline & 1995 & 11 & $2,402.2$ & $2,402.5$ & $2,402.4$ & 0.1 & 0.2 \\
\hline & 1994 & 12 & $2,402.0$ & $2,402.5$ & $2,402.3$ & 0.1 & 0.1 \\
\hline \multirow[t]{11}{*}{$\mathrm{J}-12$} & ${ }^{a_{1992-93}}$ & $a_{36}$ & $a_{2,387.9}$ & $a_{2,389.0}$ & $2,388.3$ & 0.1 & N/A \\
\hline & 2003 & 18 & $2,388.4$ & $2,389.0$ & $2,388.8$ & 0.1 & 0.5 \\
\hline & 2002 & 16 & $2,388.4$ & $2,388.8$ & $2,388.6$ & 0.1 & 0.3 \\
\hline & 2001 & 18 & $2,388.3$ & $2,388.6$ & $2,388.5$ & 0.1 & 0.2 \\
\hline & 2000 & 14 & $2,387.9$ & $2,388.6$ & $2,388.4$ & 0.1 & 0.1 \\
\hline & 1999 & 12 & $2,388.1$ & $2,388.5$ & $2,388.3$ & 0.1 & 0.0 \\
\hline & 1998 & 17 & $2,387.9$ & $2,388.3$ & $2,388.0$ & 0.1 & -0.3 \\
\hline & 1997 & 16 & $2,387.7$ & $2,388.4$ & $2,388.0$ & 0.1 & -0.3 \\
\hline & 1996 & 18 & $2,387.5$ & $2,388.5$ & $2,388.0$ & 0.1 & -0.3 \\
\hline & 1995 & 16 & $2,388.0$ & $2,388.3$ & $2,388.2$ & 0.1 & -0.1 \\
\hline & 1994 & 24 & $2,387.8$ & $2,389.1$ & $2,388.2$ & 0.2 & -0.1 \\
\hline \multirow[t]{11}{*}{ JF-3 } & $1992-93$ & 582 & $2,387.7$ & $2,388.8$ & $2,388.3$ & 0.1 & N/A \\
\hline & 2003 & 365 & $2,388.3$ & $2,389.3$ & $2,388.8$ & 0.1 & 0.5 \\
\hline & 2002 & 314 & $2,388.1$ & $2,389.0$ & $2,388.6$ & 0.1 & 0.3 \\
\hline & 2001 & 331 & $2,388.1$ & $2,389.0$ & $2,388.5$ & 0.1 & 0.2 \\
\hline & 2000 & 366 & $2,387.9$ & $2,388.8$ & $2,388.4$ & 0.1 & 0.1 \\
\hline & 1999 & 365 & $2,387.6$ & $2,388.6$ & $2,388.2$ & 0.1 & -0.1 \\
\hline & 1998 & 316 & $2,387.6$ & $2,388.6$ & $2,388.0$ & 0.1 & -0.3 \\
\hline & 1997 & 345 & $2,387.4$ & $2,388.8$ & $2,388.0$ & 0.1 & -0.3 \\
\hline & 1996 & 359 & $2,387.5$ & $2,388.5$ & $2,388.0$ & 0.1 & -0.3 \\
\hline & 1995 & 347 & $2,387.7$ & $2,388.4$ & $2,388.1$ & 0.1 & -0.2 \\
\hline & 1994 & 284 & $2,387.6$ & $2,388.6$ & $2,388.1$ & 0.1 & -0.2 \\
\hline
\end{tabular}

\footnotetext{
${ }^{a}$ Information revised from that in previous reports on selected ground-water data for the Yucca Mountain region. Revisions are due to changed baseline periods or further review of data.
} 
Since 1879, the U.S. Geological Survey has been providing maps, reports, and information to help others who manage, develop, and protect our Nation's water, energy, mineral, land, and biological resources. We help find natural resources, and we supply scientific understanding needed to help minimize or mitigate the effects of natural hazards and the environmental damage caused by human activities. The results of our efforts touch the daily lives of almost everyone. 